Supporting Information

for

\title{
Sequential Connection of Mutually Exclusive Catalytic Reactions by a Method Controlling the Presence of a MOF Catalyst: One-Pot Oxidation of Alcohols to Carboxylic Acids
}

Seongwoo Kim, ${ }^{\dagger, \S, \pi}$ Ha-Eun Lee, ${ }^{\dagger, \S}$ Jong-Min Suh, ${ }^{\ddagger}$ Mi Hee Lim, ${ }^{*, \ddagger}$ and Min Kim ${ }^{*, \dagger}$

tDepartment of Chemistry, Chungbuk National University, Cheongju 28644, Korea

‡Department of Chemistry, Korea Advanced Institute of Science and Technology (KAIST),

Daejeon 34141, Korea

IPresent Address: Materials Architecturing Research Center, Korea Institute of Science and Technology, Seoul 02792, Korea

E-mail: miheelim@kaist.ac.kr (M.H.L.) and minkim@chungbuk.ac.kr (M.K.)

Table of Contents

\begin{tabular}{|l|l|}
\hline General Materials and Methods & $\mathrm{S} 2$ \\
\hline Synthesis of TPDC-TEMPO & $\mathrm{S} 2$ \\
\hline MOF Preparation: MOF-TEMPO (UiO-68-TEMPO) & $\mathrm{S} 4$ \\
\hline MOF Characterizations & $\mathrm{S} 4$ \\
\hline General Procedure for MOF-TEMPO in-and-out method & $\mathrm{S} 5$ \\
\hline General GC Conditions & $\mathrm{S} 5$ \\
\hline Characterizations of Carboxylic Acids & $\mathrm{S} 5$ \\
\hline Procedures for Control Experiments & $\mathrm{S} 10$ \\
\hline Procedures for in-situ NMR Experiments of the Second Step & $\mathrm{S} 12$ \\
\hline Procedures for in-situ NMR Experiments of Radical Trapping with NHC-Carbene & $\mathrm{S} 12$ \\
\hline Procedures and Method for EPR Experiments & $\mathrm{S} 13$ \\
\hline Procedure for Reusability Test & $\mathrm{S} 13$ \\
\hline Appendix: Spectral Copies of ${ }^{1}{ }^{H}$ and ${ }^{13}$ C NMR of Obtained Compounds & $\mathrm{S} 27$ \\
\hline References & $\mathrm{S} 69$ \\
\hline
\end{tabular}




\section{General Materials and Methods}

All commercial reagents, reaction solvents, and NMR solvents used without additional purifications. All chemicals reagents and solvents were purchased from Sigma-Aldrich, TCl, Alfa-Aesar, and Acros chemical companies. NMR solvents were purchased from Cambridge Isotope Laboratories and Eurisotop companies. Flash column chromatography separations were performed with 400-630 mesh $\mathrm{SiO}_{2}$.

${ }^{1} \mathrm{H}$ NMR (Nuclear Magnetic Resonance) spectra was measured on Bruker AVANCE 500 NMR spectrometer $(500 \mathrm{MHz})$ and Bruker AVANCE $400(400 \mathrm{MHz})$. Chemical shifts were quoted in parts per million (ppm) referenced to the appropriate solvent peak and/or tetramethylsilane (TMS). The following abbreviations were used to describe peak patterns when appropriate: $b r=$ broad, $s=$ singlet, $d=$ doublet, $\mathrm{dd}=$ doublet of doublet, $\mathrm{ddd}=$ doublet of doublet of doublet, $\mathrm{dt}=$ doublet of triplet, $\mathrm{t}=$ triplet, $\mathrm{q}=$ quartet, quin $=$ quintet and $m=$ multiplet. Coupling constant, $J$, was reported in Hertz unit $(\mathrm{Hz}) .{ }^{13} \mathrm{C}$ NMR spectra was recorded on Bruker AVANCE 500 NMR spectrometer (125 MHz) and Bruker AVANCE 400 (100 $\mathrm{MHz}$ ) and was fully decoupled with ${ }^{1} \mathrm{H}$ by broad band decoupling.

PXRD (Powder X-ray diffraction) data were collected on Rigaku Miniflex 600 (at $40 \mathrm{kV}, 15 \mathrm{~mA}$ ) with a scan speed of $1.0 \mathrm{~min} / \mathrm{step}$, a step size of $0.02{ }^{\circ}$ in $2 \theta$, and a $2 \theta$ range of 3-50 ${ }^{\circ}$. Nitrogen sorption isotherms of samples were obtained using a ASAP2020 at $77 \mathrm{~K}$. GC (Gas Chromatography) analysis for determination of conversions was performed on an Younglin YL-6500. X-band (9.4 GHz) CW-EPR (Continuous-Wave Electron Paramagnetic Resonance) spectroscopic spectra were collected on a Bruker EMX plus 9.5/2.7 spectrometer equipped with a variable temperature control unit (Bruker ER4141 VT).

\section{Synthesis of TPDC-TEMPO}<smiles>CC1(C)CC(NC(=O)c2cc(Br)ccc2Br)CC(C)(C)N1O</smiles>
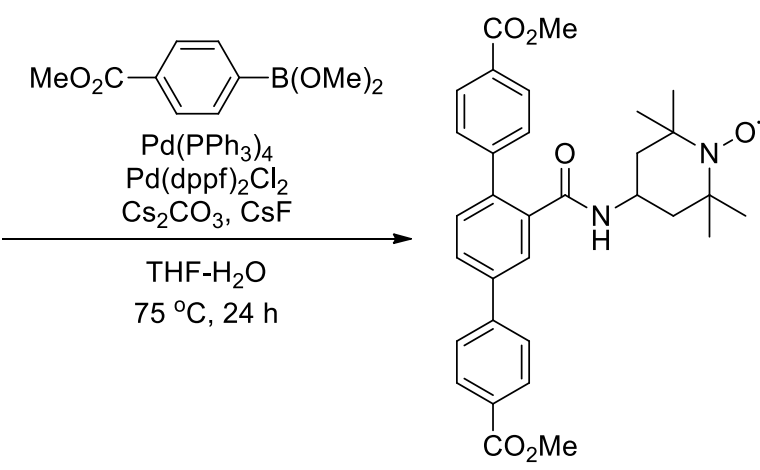

TPDCE-TEMPOS1: Ph-Br2-TEMPO (TEMPO = 2,2,6,6-tetramethylpiperidin-1-yl)oxyl, $4.0 \mathrm{~g}, 9.3 \mathrm{mmol}$ ), 4-methoxycarbonylphenylboronic acid pinacol ester (5.6 g, $21.4 \mathrm{mmol}), \operatorname{Pd}\left(\mathrm{PPh}_{3}\right)_{4}(0.32 \mathrm{~g}, 0.28 \mathrm{mmol})$, and $\mathrm{Pd}(\mathrm{dppf}) \mathrm{Cl}_{2}(0.76 \mathrm{~g}, 0.93 \mathrm{mmol})$ were dissolved in THF (THF = tetrahydrofuran, $\left.95 \mathrm{~mL}\right) . \mathrm{CsCO}_{3}$ 
$(9.1 \mathrm{~g}, 27.8 \mathrm{mmol})$ and $\mathrm{CsF}(0.7 \mathrm{~g}, 4.6 \mathrm{mmol})$ were dissolved in $\mathrm{H}_{2} \mathrm{O}(4.6 \mathrm{~mL})$, and added to the THF reaction mixture. The mixture solution was reflux at $75{ }^{\circ} \mathrm{C}$ in heating mantle for $24 \mathrm{~h}$ under $\mathrm{N}_{2}$ atmosphere. After cooling to room temperature, the mixture was filtered, and THF was evaporated. The solid was dissolved by dichloromethane $\left(\mathrm{CH}_{2} \mathrm{Cl}_{2}\right)$ and extracted with water. The combined organic phase was dried with $\mathrm{MgSO}_{4}$ and concentrated under reduced pressure. The crude product was purified by silica gel column chromatography (1:3 = ethylacetate $(E t O A c): n$-hexane) to yield TPDCE-TEMPO as a light pink solid $(4.1 \mathrm{~g}, 81 \%) .{ }^{1} \mathrm{H}$ NMR $\left(500 \mathrm{MHz}\right.$, DMSO- $d_{6}$ with phenylhydrazine $) \delta 8.12-8.11(\mathrm{~m}$, $1 \mathrm{H})$, 8.09-8.07 (m, 2H), 8.00-7.99 (m, 2H), 7.94-7.93 (m, 2H), 7.92-7.90 (m, 1H), $7.78(\mathrm{~m}, 1 \mathrm{H}), 7.58-$ $7.55(\mathrm{~m}, 3 \mathrm{H}), 3.98-3.93(\mathrm{~m}, 1 \mathrm{H}), 3.89(\mathrm{~s}, 3 \mathrm{H}), 3.88(\mathrm{~s}, 3 \mathrm{H}), 1.55-1.53(\mathrm{~m}, 2 \mathrm{H}), 1.20-1.15(\mathrm{~m}, 2 \mathrm{H}), 1.03-$ $1.01(\mathrm{~m}, 12 \mathrm{H}) ;{ }^{13} \mathrm{C}\left\{{ }^{1} \mathrm{H}\right\}$ NMR $(125 \mathrm{MHz}$, DMSO-d $) \delta 167.3,165.8,165.7,144.2,143.0,137.8,137.8$, $137.7,130.1$, 129.6, 128.7, 128.5, 128.5, 128.0, 127.4, 126.7, 125.8, 57.4, 51.9, 51.8, 44.0, 40.3, 32.3, 19.3.
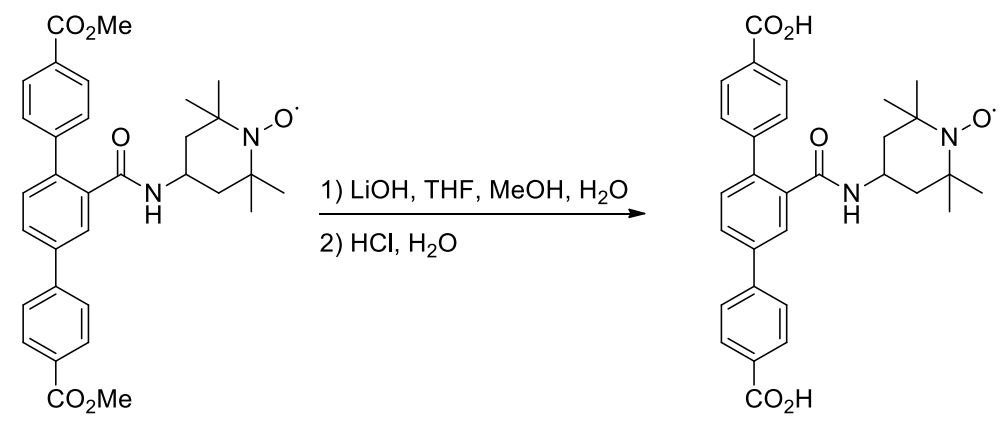

TPDC-TEMPO ${ }^{51}$ : TPDCE-TEMPO $(2 \mathrm{~g}, 3.7 \mathrm{mmol})$ was dissolved in a mixture of THF $(60 \mathrm{~mL})$ and $\mathrm{MeOH}(6 \mathrm{~mL})$. $\mathrm{LiOH}(0.7 \mathrm{~g}, 29.3 \mathrm{mmol})$ was dissolved in $\mathrm{H}_{2} \mathrm{O}(27 \mathrm{~mL})$, and added to the THF reaction mixture. The mixture solution was heated at $50{ }^{\circ} \mathrm{C}$ in heating mantle for $12 \mathrm{~h}$. After cooling to room temperature, THF and methanol $\left(\mathrm{CH}_{3} \mathrm{OH}\right)$ were evaporated under reduced pressure. The mixture was filtered by passage through Celite and washed with $\mathrm{H}_{2} \mathrm{O}$. The aqueous phase was adjusted to $\mathrm{pH} 3$ with aqueous $1 \mathrm{M} \mathrm{HCl}$ solution. The pale pink precipitates were collected by filtration, washed with $\mathrm{H}_{2} \mathrm{O}$ and dried under vacuum $(1.8 \mathrm{~g}, 95 \%) .{ }^{1} \mathrm{H}$ NMR $\left(500 \mathrm{MHz}\right.$, DMSO- $d_{6}$ with phenylhydrazine) $\delta 8.11-8.10(\mathrm{~m}$, $1 \mathrm{H})$, 8.08-8.06 (m, 2H), 7.99-7.97 (m, 2H), 7.91-7.89 (m, 3H), $7.77(\mathrm{~m}, 1 \mathrm{H})$, 7.57-7.53 (m, 3H), 4.01$3.56(\mathrm{~m}, 1), 1.56-1.53(\mathrm{~m}, 2 \mathrm{H}), 1.22-1.17(\mathrm{~m}, 2 \mathrm{H}), 1.04-1.02(\mathrm{~m}, 12 \mathrm{H}) ;{ }^{13} \mathrm{C}\left\{{ }^{1} \mathrm{H}\right\}$ NMR $(125 \mathrm{MHz}$, DMSO$\left.d_{6}\right) \delta 167.4,167.1,167.0,143.7,142.6,137.9,137.8,130.1,130.0,129.8,129.7,128.8,128.3,128.0$, $127.4,126.5,125.8,57.9,43.8,40.2$, 31.9, 19.3. 


\section{MOF Preparation: MOF-TEMPO (UiO-68-TEMPO)}

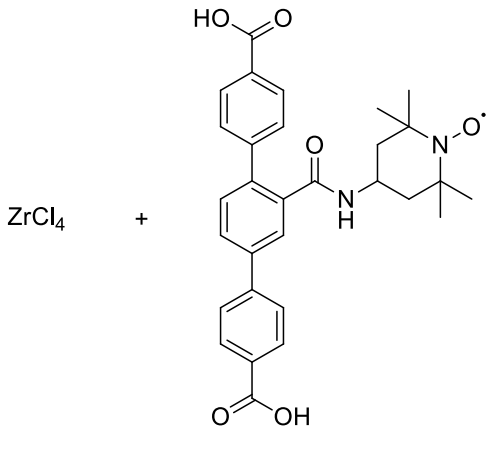

TPDC-TEMPO

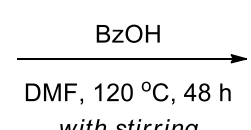

with stirring

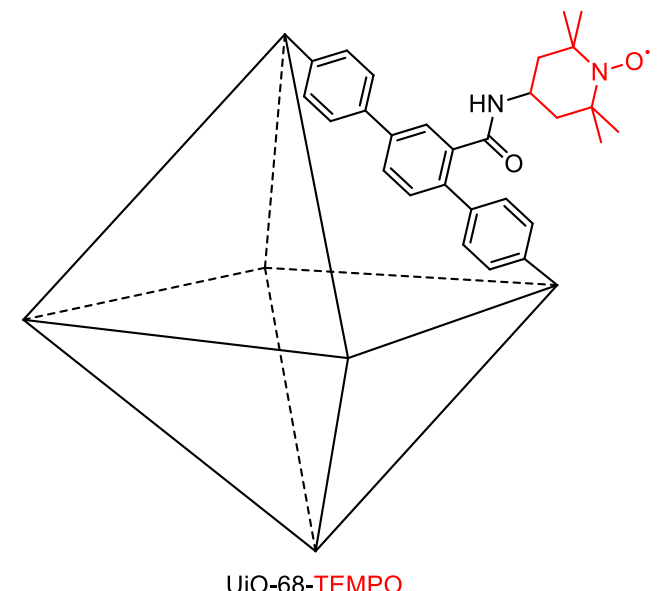

UiO-68-TEMPO

MOF-TEMPO (UiO-68-TEMPO)S1: TPDC-TMEPO (214 mg, $0.42 \mathrm{mmol}$ ), $\mathrm{ZrCl}_{4}(96 \mathrm{mg}, 0.42 \mathrm{mmo}$ ), and benzoic acid (BzOH, $760 \mathrm{mg}, 6.2 \mathrm{mmol})$ were charged in a round bottom flask $(250 \mathrm{~mL})$ with a magnetic stirring bar $(3 \mathrm{~mm} \times 6 \mathrm{~mm}$ ), and the solid mixtures were fully dissolved in DMF (DMF $=N, N$ dimethylformamide, $16 \mathrm{~mL})$. The mixture was stirred $(300 \mathrm{rpm})$ at $120^{\circ} \mathrm{C}$ in heating mantle for $48 \mathrm{~h}$, and then cooled to room temperature. The pale pink, octahedral crystals were isolated by filtration and washed 5 times with fresh DMF $(5 \times 10 \mathrm{~mL})$, washed 5 times with $\mathrm{CH}_{3} \mathrm{OH}(5 \times 10 \mathrm{~mL})$, and washed 5 times with acetonitrile $\left(\mathrm{CH}_{3} \mathrm{CN} ; 5 \times 10 \mathrm{~mL}\right)$. Then heating at $40{ }^{\circ} \mathrm{C}$ under vacuum for $12 \mathrm{~h}$ yielded the activated MOF-TEMPO. This procedure was prepared by a reported method with minor modifications.

\section{MOF Characterizations}

MOF digestion: approximately $10 \mathrm{mg}$ of MOFs were dried under vacuum and digested with sonication in $590 \mu \mathrm{L}$ of DMSO- $d_{6}$ and $10 \mu \mathrm{L}$ of $\mathrm{HF}$ (48\% aqueous solution).

PXRD (Powder X-ray diffraction): PXRD data was collected at ambient temperature on a Rigaku Miniflex at $40 \mathrm{kV}, 15 \mathrm{~mA}$ for CuKa $(\lambda=1.5406 \AA)$, with a scan speed of $1 \mathrm{sec} / \mathrm{step}$, a step size of $0.02 \circ$ in $2 \theta$, and a $2 \theta$ range of $3-40^{\circ}$.

$\mathbf{N}_{\mathbf{2}}$ full isotherm for MOF-TEMPO: approximately $30-60 \mathrm{mg}$ of MOF sample was evacuated under vacuum for a moment at room temperature. Samples were then transferred to a pre-weighed sample tube and degassed at $150^{\circ} \mathrm{C}$ on an ASAP2020 for a minimum of $24 \mathrm{~h}$ or until the outgas rate was $<5$ $\mu \mathrm{m} \mathrm{Hg} / \mathrm{min}$. The sample tube was re-weighted to obtain a consistent mass for the degassed MOF materials.

\section{General Procedure for MOF-TEMPO in-and-out method}


General Procedure: alcohol reagent $(0.25 \mathrm{mmol})$, MOF-TEMPO ( $8 \mathrm{mg}, 0.0125 \mathrm{mmol})$, and $\mathrm{CH}_{3} \mathrm{CN}$ (1 $\mathrm{mL}$ ) were added to a scintillation vial. tert-butyl nitrite $(5 \mathrm{mg}, 0.05 \mathrm{mmol})$ was added to the solution mixture, and then the mixture was stirred at $25^{\circ} \mathrm{C}$ for $2-24 \mathrm{~h}$ under the $\mathrm{O}_{2}$ balloon ( $1 \mathrm{~atm}$ ). The reaction was monitored by TLC (thin-layer chromatography). When conversion of alcohol to aldehyde was complete (by TLC monitoring), subsequently MOF-TEMPO was recovered from the reaction mixture by syringe filter. Approximately $2 \times 0.25 \mathrm{~mL}$ of a solvent (mainly $\mathrm{CH}_{3} \mathrm{CN}$ or 1,2-dichloroethane or 1,4dioxane by substrate) was used to prevent the loss of the yield. Then the reaction mixture was stirred for the second step under the $\mathrm{O}_{2}$ balloon ( $1 \mathrm{~atm}$ ) at $80{ }^{\circ} \mathrm{C}$ for $10-24 \mathrm{~h}$. After completion (monitored by TLC), the desired product was isolated by a silica gel column chromatography with EtOAc and $n$-hexane.

\section{General GC Conditions}

GC-Condition: DB-5 column, $30 \mathrm{~m} \times 0.32 \mathrm{~mm}$ (id); FID detector, $300^{\circ} \mathrm{C}$; injection: $200^{\circ} \mathrm{C}$; carrier gas: $\mathrm{N}_{2}$; carrier gas rate: $1 \mathrm{~mL} / \mathrm{min}$; area normalization.

- Benzoic acid (3a) was detected under a condition as column temperature: $120^{\circ} \mathrm{C}$ for $2 \mathrm{~min}$, increasing to $190^{\circ} \mathrm{C}$ in a rate of $10^{\circ} \mathrm{C} / \mathrm{min}$, then increasing to $280^{\circ} \mathrm{C}$ in a rate of $30^{\circ} \mathrm{C}$.

\section{Characterizations of Carboxylic Acids}

\section{Benzoic acid (3a) $)^{\mathrm{S} 2}$}

The reaction was stirred at $25^{\circ} \mathrm{C}$ for $2 \mathrm{~h}$ followed by filtration of MOF-TEMPO, and it was stirred at 80 ${ }^{\circ} \mathrm{C}$ for $10 \mathrm{~h}$. Desired product was isolated by flash column purification with EtOAc/n-hexane (1/30 to 1/2, $\mathrm{v} / \mathrm{v}$ ) as the eluent. Isolation yield (29 mg, 96\%, a colorless solid); ${ }^{1} \mathrm{H} \mathrm{NMR}\left(500 \mathrm{MHz}, \mathrm{CDCl}_{3}\right) \delta 11.69$ (br, 1H) 8.15-8.13 (m, 2H), 7.65-7.61 (m, 1H), 7.51-7.47 (m, 2H); ${ }^{13} \mathrm{C}\left\{{ }^{1} \mathrm{H}\right\} \mathrm{NMR}\left(125 \mathrm{MHz}, \mathrm{CDCl}_{3}\right) \delta$ 172.6, 134.0, 130.4, 129.4, 128.6 .

\section{4-Methylbenzoic acid (3b) ${ }^{\mathrm{S} 2}$}

The reaction was stirred at $25^{\circ} \mathrm{C}$ for $4 \mathrm{~h}$ followed by filtration of MOF-TEMPO, and it was stirred at 80 ${ }^{\circ} \mathrm{C}$ for $10 \mathrm{~h}$. Desired product was isolated by flash column purification with EtOAc/n-hexane (1/30 to 1/2, $\mathrm{v} / \mathrm{v}$ ) as the eluent. Isolation yield (33 mg, 97\%, a colorless solid); ${ }^{1} \mathrm{H}$ NMR (500 MHz, DMSO-d $) \delta 12.79$ (br, 1H), 7.84-7.82 (m, 2H), 7.31-7.29 (m, 2H), $2.37(\mathrm{~s}, 3 \mathrm{H}) ;{ }^{13} \mathrm{C}\left\{{ }^{1} \mathrm{H}\right\} \mathrm{NMR}\left(125 \mathrm{MHz}, \mathrm{DMSO}-\mathrm{d}_{6}\right) \delta$ 167.4, $143.1,129.4,129.2,128.1,21.2$.

\section{3-Methylbenzoic acid (3c) $)^{\mathrm{S} 2}$}

The reaction was stirred at $25^{\circ} \mathrm{C}$ for $12 \mathrm{~h}$ followed by filtration of MOF-TEMPO, and it was stirred at 80 ${ }^{\circ} \mathrm{C}$ for $12 \mathrm{~h}$. Desired product was isolated by flash column purification with EtOAc/n-hexane (1/30 to 1/2, $\mathrm{v} / \mathrm{v}$ ) as the eluent. Isolation yield (31 mg, $92 \%$, a colorless solid); ${ }^{1} \mathrm{H}$ NMR (500 MHz, DMSO-d6) $\delta 12.88$ 
(br, $1 \mathrm{H}), 7.76(\mathrm{~m}, 1 \mathrm{H}), 7.75-7.73(\mathrm{~m}, 1 \mathrm{H}), 7.44-7.42(\mathrm{~m}, 1 \mathrm{H}), 7.39-7.36(\mathrm{~m}, 1 \mathrm{H}), 2.36(\mathrm{~s}, 3 \mathrm{H}) ;{ }^{13} \mathrm{C}\left\{{ }^{1} \mathrm{H}\right\}$ NMR (125 MHz, DMSO-d6) $\delta$ 167.5, 137.9, 133.5, 130.7, 129.8, 128.5, 126.5, 20.8.

\section{2-Methylbenzoic acid (3d) $)^{\mathrm{S} 2}$}

The reaction was stirred at $25^{\circ} \mathrm{C}$ for $18 \mathrm{~h}$ followed by filtration of MOF-TEMPO, and it was stirred at 80 ${ }^{\circ} \mathrm{C}$ for $24 \mathrm{~h}$. Desired product was isolated by flash column purification with EtOAc/n-hexane (1/30 to 1/2, $\mathrm{v} / \mathrm{v}$ ) as the eluent. Isolation yield (32.7 mg, $96 \%$, a colorless solid); ${ }^{1} \mathrm{H}$ NMR (500 MHz, DMSO- $\left.d_{6}\right) \delta$ 12.81 (br, 1H), 7.82-7.80 (dd, $1 \mathrm{H}, J=7.7,1.3 \mathrm{~Hz}$ ), 7.45-7.42 (td, $1 \mathrm{H}, J=7.5,1.4 \mathrm{~Hz}$ ), 7.30-7.26 (m, 2H); ${ }^{13} \mathrm{C}\left\{{ }^{1} \mathrm{H}\right\}$ NMR $(125 \mathrm{MHz}$, DMSO-d $) \delta 168.7$ 139.0, 131.7, 131.5, 130.5, 130.2, 125.9, 21.3.

\section{4-lodobenzoic acid $(3 \mathbf{e})^{\mathrm{S3}}$}

The reaction was stirred at $25^{\circ} \mathrm{C}$ for $24 \mathrm{~h}$ followed by filtration of MOF-TEMPO, and it was stirred at 80 ${ }^{\circ} \mathrm{C}$ for $12 \mathrm{~h}$. Desired product was isolated by flash column purification with EtOAc/n-hexane (1/10 to 1/1, $\mathrm{v} / \mathrm{v}$ ) as the eluent. Isolation yield ( $52 \mathrm{mg}, 83 \%$ ) obtained as a colorless solid; ${ }^{1} \mathrm{H}$ NMR ( $500 \mathrm{MHz}$, DMSO$\left.d_{6}\right) \delta 13.15(\mathrm{br}, 1 \mathrm{H}), 7.90-7.88(\mathrm{~m}, 2 \mathrm{H}), 7.70-7.67(\mathrm{~m}, 2 \mathrm{H}) ;{ }^{13} \mathrm{C}\left\{{ }^{1} \mathrm{H}\right\} \mathrm{NMR}\left(125 \mathrm{MHz}, \mathrm{DMSO}-d_{6}\right) \delta 166.9$, 137.6, 131.1, 130.3, 101.3.

\section{4-Bromobenzoic acid (3f) ${ }^{\mathrm{S} 2}$}

The reaction was stirred at $25^{\circ} \mathrm{C}$ for $24 \mathrm{~h}$ followed by filtration of MOF-TEMPO, and it was stirred at 80 ${ }^{\circ} \mathrm{C}$ for $12 \mathrm{~h}$ Desired product was isolated by flash column purification with EtOAc/ $n$-hexane (1/10 to 1/1, $\mathrm{v} / \mathrm{v})$ as the eluent. Isolation yield (45 mg, $90 \%)$ obtained as a light yellow solid; ${ }^{1} \mathrm{H}$ NMR $(500 \mathrm{MHz}$, DMSO-d $\left.d_{6}\right) 13.19(\mathrm{br}, 1 \mathrm{H}), 7.87-7.85(\mathrm{~m}, 2 \mathrm{H}), 7.72-7.70(\mathrm{~m}, 2 \mathrm{H}) ;{ }^{13} \mathrm{C}\left\{{ }^{1} \mathrm{H}\right\} \mathrm{NMR}(125 \mathrm{MHz}$, DMSO-d $) \delta$ 166.7, 131.7, 131.3, 130.1, 126.9.

\section{4-Fluorobenzoic acid $(\mathbf{3 g})^{\mathrm{s} 2}$}

The reaction was stirred at $25^{\circ} \mathrm{C}$ for $8 \mathrm{~h}$ followed by filtration of MOF-TEMPO, and it was stirred at 80 ${ }^{\circ} \mathrm{C}$ for $12 \mathrm{~h}$. Desired product was isolated by flash column purification with EtOAc/n-hexane (1/20 to 1/1, $\mathrm{v} / \mathrm{v}$ ) as the eluent. Isolation yield ( $32 \mathrm{mg}, 91 \%$ ) obtained as a colorless solid; ${ }^{1} \mathrm{H}$ NMR ( $500 \mathrm{MHz}$, DMSOd $) \delta 13.06(\mathrm{br}, 1 \mathrm{H}), 8.02-7.99(\mathrm{~m}, 2 \mathrm{H}), 7.34-7.30(\mathrm{~m}, 2 \mathrm{H}) ;{ }^{13} \mathrm{C}\left\{{ }^{1} \mathrm{H}\right\} \mathrm{NMR}\left(125 \mathrm{MHz}\right.$, DMSO-d $\left.\mathrm{d}_{6}\right) \delta$ 166.4, 165.9-163.9 (d, $\left.J^{1} \mathrm{C}-\mathrm{F}=248.8 \mathrm{~Hz}\right), 132.2-132.1\left(\mathrm{~d}, J^{3} \mathrm{C}-\mathrm{F}=9.3 \mathrm{~Hz}\right), 127.4-127.4\left(\mathrm{~d}, J^{4} \mathrm{C}-\mathrm{F}=2.5 \mathrm{~Hz}\right), 115.7-$ $115.6\left(\mathrm{~d}, \mathrm{~J}^{2} \mathrm{C}-\mathrm{F}=21.9 \mathrm{~Hz}\right)$.

\section{4-Chlorobenzoic acid $(3 \mathrm{~h})^{\mathrm{S} 2}$}

The reaction was stirred at $25^{\circ} \mathrm{C}$ for $24 \mathrm{~h}$ followed by filtration of MOF-TEMPO, and it was stirred at 80 ${ }^{\circ} \mathrm{C}$ for $24 \mathrm{~h}$. Desired product was isolated by flash column purification with EtOAc/n-hexane (1/20 to 1/1, $\mathrm{v} / \mathrm{v}$ ) as the eluent. Isolation yield ( $39 \mathrm{mg}, 99 \%$ ) obtained as a colorless solid; ${ }^{1} \mathrm{H}$ NMR ( $500 \mathrm{MHz}$, DMSOd6) $\delta 13.19(\mathrm{br}, 1 \mathrm{H}), 7.95-7.92(\mathrm{~m}, 2 \mathrm{H}), 7.58-7.55(\mathrm{~m}, 2 \mathrm{H}) ;{ }^{13} \mathrm{C}\left\{{ }^{1} \mathrm{H}\right\} \mathrm{NMR}\left(125 \mathrm{MHz}, \mathrm{DMSO}-\mathrm{d}_{6}\right) \delta 166.5$, $137.9,131.2,129.7,128.8$. 


\section{3-Chlorobenzoic acid (3i) $)^{\mathrm{S} 2}$}

The reaction was stirred at $25^{\circ} \mathrm{C}$ for $24 \mathrm{~h}$ followed by filtration of MOF-TEMPO, and it was stirred at 80 ${ }^{\circ} \mathrm{C}$ for $24 \mathrm{~h}$. Desired product was isolated by flash column purification with EtOAc/n-hexane (1/20 to 1/1, $\mathrm{v} / \mathrm{v}$ ) as the eluent. Isolation yield ( $39 \mathrm{mg}, 99 \%$ ) obtained as a colorless solid; ${ }^{1} \mathrm{H}$ NMR ( $500 \mathrm{MHz}$, DMSOd6) $\delta 13.35(\mathrm{br}, 1 \mathrm{H}), 7.91-7.88(\mathrm{~m}, 2 \mathrm{H}), 7.72-7.70(\mathrm{~m}, 1 \mathrm{H}), 7.55-7.53(\mathrm{~m}, 1 \mathrm{H}) ;{ }^{13} \mathrm{C}\left\{{ }^{1} \mathrm{H}\right\} \mathrm{NMR}(125 \mathrm{MHz}$, DMSO- $\left.d_{6}\right) \delta 166.1,133.4,132.9,132.8,130.7,128.9,128.0$.

\section{2-Chlorobenzoic acid (3j) $)^{\mathrm{S2}}$}

The reaction was stirred at $25^{\circ} \mathrm{C}$ for $24 \mathrm{~h}$ followed by filtration of MOF-TEMPO, and it was stirred at 80 ${ }^{\circ} \mathrm{C}$ for $24 \mathrm{~h}$. Desired product was isolated by flash column purification with EtOAc/n-hexane (1/20 to 1/1, $\mathrm{v} / \mathrm{v}$ ) as the eluent. Isolation yield ( $38 \mathrm{mg}, 98 \%$ ) obtained as a colorless solid; ${ }^{1} \mathrm{H}$ NMR ( $500 \mathrm{MHz}$, DMSOd6) $\delta 13.39(\mathrm{br}, 1 \mathrm{H}), 7.79-7.77(\mathrm{~m}, 1 \mathrm{H}), 7.54-7.53(\mathrm{~m}, 2 \mathrm{H}), 7.44-7.41(\mathrm{~m}, 1 \mathrm{H}) ;{ }^{13} \mathrm{C}\left\{{ }^{1} \mathrm{H}\right\} \mathrm{NMR}(125 \mathrm{MHz}$, DMSO-d6) $\delta 166.8,132.6,131.6,131.5,130.9,130.7,127.3$.

\section{2,4-Dichlorobenzoic acid $(3 k)^{53}$}

The reaction was stirred at $25^{\circ} \mathrm{C}$ for $24 \mathrm{~h}$ followed by filtration of MOF-TEMPO, and it was stirred at 80 ${ }^{\circ} \mathrm{C}$ for $24 \mathrm{~h}$. Desired product was isolated by flash column purification with EtOAc/n-hexane (1/20 to 1/1, $\mathrm{v} / \mathrm{v}$ ) as the eluent. Isolation yield ( $42 \mathrm{mg}, 87 \%$ ) obtained as a colorless solid; ${ }^{1} \mathrm{H}$ NMR ( $500 \mathrm{MHz}$, DMSOd6) $\delta 13.58(\mathrm{br}, 1 \mathrm{H}), 7.83-7.77(\mathrm{~d}, 1 \mathrm{H}, J=8.4 \mathrm{~Hz}), 7.72-7.72(\mathrm{~d}, 1 \mathrm{H}, J=2.0 \mathrm{~Hz}), 7.53-7.51(\mathrm{dd}, 1 \mathrm{H}, J=$ 8.4, $2.1 \mathrm{~Hz}) ;{ }^{13} \mathrm{C}\left\{{ }^{1} \mathrm{H}\right\} \mathrm{NMR}(125 \mathrm{MHz}$, DMSO-d $) \delta$ 165.9, 136.5, 133.0, 132.4, 130.2, 127.5 .

\section{4-(Trifluoromethyl)benzoic acid (3I) ${ }^{\mathrm{S} 2}$}

The reaction was stirred at $25^{\circ} \mathrm{C}$ for $12 \mathrm{~h}$ followed by filtration of MOF-TEMPO, and it was stirred at 80 ${ }^{\circ} \mathrm{C}$ for $24 \mathrm{~h}$. Desired product was isolated by flash column purification with EtOAc/n-hexane (1/20 to 1/1, $\mathrm{v} / \mathrm{v}$ ) as the eluent. Isolation yield ( $47 \mathrm{mg}, 98 \%$ ) obtained as a colorless solid; ${ }^{1} \mathrm{H}$ NMR ( $500 \mathrm{MHz}$, DMSOd6) $\delta 13.47(\mathrm{~s}, 1 \mathrm{H}), 8.14-8.13(\mathrm{~d}, 2 \mathrm{H}, J=5 \mathrm{~Hz}), 7.88-7.86(\mathrm{~d}, 2 \mathrm{H}, J=10 \mathrm{~Hz}) ;{ }^{3} \mathrm{C}\left\{{ }^{1} \mathrm{H}\right\} \mathrm{NMR}(125 \mathrm{MHz}$, DMSO- $\left.d_{6}\right) \delta 166.2,134.6,132.9-132.1\left(q, J^{2} \mathrm{C}-\mathrm{F}=31.5 \mathrm{~Hz}\right.$ ), 130.1, 127.1-120.6 (q, J1 $\mathrm{C}-\mathrm{F}=271.2 \mathrm{~Hz}$ ), 125.6-125.6 (q, $\left.{ }^{3} \mathrm{C}-\mathrm{F}=3.5 \mathrm{~Hz}\right)$.

\section{4-Acetamidobenzoic acid $(3 \mathrm{~m})^{\mathrm{s4}}$}

The reaction was stirred at $25^{\circ} \mathrm{C}$ for $12 \mathrm{~h}$ followed by filtration of MOF-TEMPO, and it was stirred at 80 ${ }^{\circ} \mathrm{C}$ for $24 \mathrm{~h}$. Desired product was isolated by flash column purification with EtOAc/n-hexane (1/10 to 4/1, $\mathrm{v} / \mathrm{v}$ ) as the eluent. Isolation yield ( $22 \mathrm{mg}, 50 \%$ ) obtained as a colorless solid; ${ }^{1} \mathrm{H}$ NMR ( $500 \mathrm{MHz}$, DMSOd6) $\delta 12.66(\mathrm{br}, 1 \mathrm{H}), 10.23(\mathrm{br}, 1 \mathrm{H}), 7.88-7.86(\mathrm{~m}, 2 \mathrm{H}), 7.69-7.67(\mathrm{~m}, 2 \mathrm{H}), 2.08(\mathrm{~s}, 3 \mathrm{H}) ;{ }^{13} \mathrm{C}\left\{{ }^{1} \mathrm{H}\right\} \mathrm{NMR}$ $\left(125 \mathrm{MHz}, \mathrm{DMSO}-d_{6}\right) \delta 168.9,166.9,143.3,130.4,124.9,118.2,24.2$.

\section{4-Carboxylphenylboronic acid pinacol ester $(3 n)^{S 5}$}

The reaction was stirred at $25^{\circ} \mathrm{C}$ for $24 \mathrm{~h}$ followed by filtration of MOF-TEMPO, and it was stirred at 80 ${ }^{\circ} \mathrm{C}$ for $24 \mathrm{~h}$. Desired product was isolated by recrystallization with EtOAc/n-hexane. Isolation yield (36 
mg, $58 \%$ ) obtained as a colorless solid; ${ }^{1} \mathrm{H}$ NMR $\left(500 \mathrm{MHz}\right.$, DMSO- $\left.d_{6}\right) \delta 13.06(\mathrm{br}, 1 \mathrm{H})$, 7.93-7.75 (m, $2 \mathrm{H}), 7.77-7.75(\mathrm{~m}, 2 \mathrm{H}), 1.29(\mathrm{~s}, 12 \mathrm{H}) ;{ }^{13} \mathrm{C}\left\{{ }^{1} \mathrm{H}\right\} \mathrm{NMR}\left(125 \mathrm{MHz}, \mathrm{DMSO}-\mathrm{d}_{6}\right) \delta$ 167.5, 134.1, 132.0, 128.1, 82.9, 24.9.

\section{Terephthalic acid $(30)^{\mathrm{S} 2}$}

The reaction was stirred at $25^{\circ} \mathrm{C}$ for $12 \mathrm{~h}$ followed by filtration of MOF-TEMPO, and it was stirred at 80 ${ }^{\circ} \mathrm{C}$ for $12 \mathrm{~h}$. Desired product was isolated by recrystallization with EtOAc/n-hexane. Isolation yield (34 mg, 81\%) obtained as a colorless solid; ${ }^{1} \mathrm{H}$ NMR (500 MHz, DMSO-d6) $\delta 13.30(\mathrm{br}, 1 \mathrm{H}), 8.04(\mathrm{~s}, 4 \mathrm{H})$; ${ }^{13} \mathrm{C}\left\{{ }^{1} \mathrm{H}\right\}$ NMR (125 MHz, DMSO-d6) $\delta$ 166.7, 134.5, 129.5.

\section{Biphenyl-4-carboxylic acid (3p) $)^{\mathrm{S}}$}

The reaction was stirred at $25^{\circ} \mathrm{C}$ for $12 \mathrm{~h}$ followed by filtration of MOF-TEMPO, and it was stirred at 80 ${ }^{\circ} \mathrm{C}$ for $24 \mathrm{~h}$. Desired product was isolated by flash column purification with EtOAc/n-hexane (1/20 to 1/1, $\mathrm{v} / \mathrm{v})$ as the eluent. Isolation yield ( $49 \mathrm{mg}, 98 \%$ ) obtained as a colorless solid; ${ }^{1} \mathrm{H}$ NMR $(500 \mathrm{MHz}$, DMSOd6) $\delta 12.97(\mathrm{br}, 1 \mathrm{H}), 8.03-8.02(\mathrm{~d}, 2 \mathrm{H}, J=8.1 \mathrm{~Hz}), 7.81-7.79(\mathrm{~d}, 2 \mathrm{H}, J=8.1 \mathrm{~Hz}), 7.74-7.73(\mathrm{~m}, 2 \mathrm{H})$, 7.52-7.49 (m, 2H), 7.44-7.41 (m, $1 \mathrm{H}) ;{ }^{13} \mathrm{C}\left\{{ }^{1} \mathrm{H}\right\}$ NMR (125 MHz, DMSO- $\left.d_{6}\right) \delta$ 167.2, 144.3, 139.0, 130.0, 129.6, 129.1, 128.3, 127.0, 126.8 .

\section{2-Furoic acid (3q) $)^{\mathrm{S2}}$}

This compound could be obtained by using 1,4-dioxane instead of $\mathrm{CH}_{3} \mathrm{CN}$. The reaction was stirred at $25^{\circ} \mathrm{C}$ for $24 \mathrm{~h}$ followed by filtration of MOF-TEMPO, and it was stirred at $80^{\circ} \mathrm{C}$ for $24 \mathrm{~h}$. Desired product was isolated by flash column purification with EtOAc/n-hexane $(1 / 20$ to $1 / 2, \mathrm{v} / \mathrm{v})$ as the eluent. Isolation yield (22 mg, 80\%) obtained as a colorless solid; ${ }^{1} \mathrm{H}$ NMR (500 MHz, DMSO-d6) $\delta 13.05(\mathrm{br}, 1 \mathrm{H}$ ), 7.91 (dd, $1 \mathrm{H}, J=4.4,1.1 \mathrm{~Hz}), 7.21-7.20(\mathrm{dd}, 1 \mathrm{H}, J=4.4,1.1 \mathrm{~Hz}), 6.66-6.64(\mathrm{~m}, 1 \mathrm{H},) ;{ }^{13} \mathrm{C}\left\{{ }^{1} \mathrm{H}\right\} \mathrm{NMR}(125$ $\left.\mathrm{MHz}, \mathrm{DMSO}-d_{6}\right) \delta 159.4,147.1,144.9,117.8,112.1$.

\section{2,5-Furandicarboxylic acid $(3 r)^{56}$}

This compound could be obtained by using 1,4-dioxane instead of $\mathrm{CH}_{3} \mathrm{CN}$. The reaction was stirred at $25^{\circ} \mathrm{C}$ for $24 \mathrm{~h}$ followed by filtration of MOF-TEMPO, and it was stirred at $80^{\circ} \mathrm{C}$ for $24 \mathrm{~h}$. Desired product was isolated by recrystallization with $\mathrm{CH}_{2} \mathrm{Cl}_{2} / n$-hexane. Isolation yield (34 $\mathrm{mg}, 88 \%$ ) obtained as a colorless solid; ${ }^{1} \mathrm{H}$ NMR $\left(500 \mathrm{MHz}, \mathrm{CD}_{3} \mathrm{OD}\right) \delta 7.26$ (s, $\left.2 \mathrm{H}\right) ;{ }^{13} \mathrm{C}\left\{{ }^{1} \mathrm{H}\right\} \mathrm{NMR}\left(125 \mathrm{MHz}, \mathrm{CD}_{3} \mathrm{OD}\right) \delta 160.9$, $148.8,119.5$.

\section{2-Thiophenecarboxylic acid (3s) $)^{\mathrm{S} 2}$}

This compound could be obtained by using 1,4-dioxane instead of $\mathrm{CH}_{3} \mathrm{CN}$. The reaction was stirred at $25^{\circ} \mathrm{C}$ for $24 \mathrm{~h}$ followed by filtration of MOF-TEMPO, and it was stirred at $80^{\circ} \mathrm{C}$ for $24 \mathrm{~h}$. Desired product was isolated by flash column purification with EtOAc/n-hexane $(1 / 20$ to $1 / 2, \mathrm{v} / \mathrm{v})$ as the eluent. Isolation yield $(29 \mathrm{mg}, 90 \%)$ obtained as a colorless solid; ${ }^{1} \mathrm{H}$ NMR $\left(500 \mathrm{MHz}, \mathrm{CDCl}_{3}\right) \delta 7.91-7.90(\mathrm{dd}, 1 \mathrm{H}, \mathrm{J}=$ 
3.8, $1.3 \mathrm{~Hz}), 7.66-7.65(\mathrm{dd}, 1 \mathrm{H}, J=5.0,1.3 \mathrm{~Hz}), 7.16-7.14(\mathrm{dd}, 1 \mathrm{H}, J=5.0,3.8 \mathrm{~Hz}) ;{ }^{13} \mathrm{C}\left\{{ }^{1} \mathrm{H}\right\} \mathrm{NMR}(125$ $\left.\mathrm{MHz}, \mathrm{CDCl}_{3}\right) \delta 167.5,135.2,134.2,132.9,128.2$.

\section{3-Thiophenecarboxylic acid (3t) $)^{\mathrm{ST}}$}

This compound could be obtained by using 1,4-dioxane instead of $\mathrm{CH}_{3} \mathrm{CN}$. The reaction was stirred at $25^{\circ} \mathrm{C}$ for $24 \mathrm{~h}$ followed by filtration of MOF-TEMPO, and it was stirred at $80^{\circ} \mathrm{C}$ for $24 \mathrm{~h}$. Desired product was isolated by flash column purification with EtOAc/n-hexane (1/20 to 1/2, v/v) as the eluent. Isolation yield (26 mg, 82\%) obtained as a colorless solid; ${ }^{1} \mathrm{H}$ NMR $(500 \mathrm{MHz}$, DMSO-d6) $\delta 12.67(\mathrm{br}, 1 \mathrm{H}), 8.26-$ 8.25 (dd, $1 \mathrm{H}, J=3.0,1.2 \mathrm{~Hz}$ ), 7.62-7.60 (dd, $1 \mathrm{H}, J=5.0,3.0 \mathrm{~Hz}$ ), 7.43-7.41 (dd, $1 \mathrm{H}, J=5.0,1.2 \mathrm{~Hz}$ ); ${ }^{13} \mathrm{C}\left\{{ }^{1} \mathrm{H}\right\}$ NMR $\left(125 \mathrm{MHz}, \mathrm{DMSO}-d_{6}\right) \delta 163.6,134.3,133.3,127.7,127.3$.

\section{Hexanoic acid $(3 \mathbf{u})^{\mathrm{s} 2}$}

This compound could be obtained by using EtOAc instead of $\mathrm{CH}_{3} \mathrm{CN}$. The reaction was stirred at $25^{\circ} \mathrm{C}$ for $24 \mathrm{~h}$ followed by filtration of MOF-TEMPO, and it was stirred at $80^{\circ} \mathrm{C}$ for $24 \mathrm{~h}$. Desired product was isolated by flash column purification with EtOAc/n-hexane $(1 / 10, \mathrm{v} / \mathrm{v})$ as the eluent. Isolation yield (26 $\mathrm{mg}, 89 \%$ ) obtained as a colorless solid; ${ }^{1} \mathrm{H}$ NMR (500 MHz, DMSO- $\left.d_{6}\right) \delta 11.97(\mathrm{br}, 1 \mathrm{H}), 2.20-2.17(\mathrm{~m}$, $2 \mathrm{H}), 1.52-1.46(\mathrm{~m}, 2 \mathrm{H}), 1.30-1.22(\mathrm{~m}, 4 \mathrm{H}), 0.87-0.84(\mathrm{~m}, 3 \mathrm{H}) ;{ }^{13} \mathrm{C}$ NMR $\left(125 \mathrm{MHz}\right.$, DMSO- $\left.d_{6}\right) \delta$ 174.6, $33.6,30.8,24.2,21.9,13.9$.

\section{Dodecanoic acid $(3 \mathbf{w})^{\mathrm{s} 2}$}

This compound could be obtained by using EtOAc instead of $\mathrm{CH}_{3} \mathrm{CN}$. The reaction was stirred at $25^{\circ} \mathrm{C}$ for $24 \mathrm{~h}$ followed by filtration of MOF-TEMPO, and it was stirred at $80^{\circ} \mathrm{C}$ for $24 \mathrm{~h}$. Desired product was isolated by flash column purification with EtOAc/n-hexane (1/10, v/v) as the eluent. Isolation yield (46 mg, $92 \%$ ) obtained as a colorless solid; ${ }^{1} \mathrm{H}$ NMR $\left(500 \mathrm{MHz}, \mathrm{CDCl}_{3}\right) \delta 9.56(\mathrm{br}, 1 \mathrm{H}), 2.36-2.33(\mathrm{~m}, 2 \mathrm{H})$, 1.66-1.60 (m, 2H), 1.29-1.25 (m, 16H), 0.89-0.86 (m, 3H); $\left.{ }^{13} \mathrm{C} \mathrm{NMR} \mathrm{(125} \mathrm{MHz,} \mathrm{CDCl}_{3}\right) \delta 180.5,34.2$, $32.0,29.7,29.6,29.5,29.4,29.2,24.8,22.8,14.3$. 


\section{Procedures for Control Experiments}

Procedure for control experiment (a): benzyl alcohol ( $0.25 \mathrm{mmol})$, MOF-TEMPO ( $8 \mathrm{mg}, 0.0125 \mathrm{mmol}$ ), and $\mathrm{CH}_{3} \mathrm{CN}(1 \mathrm{~mL})$ were added to a scintillation vial. tert-Butyl nitrite $(5 \mathrm{mg}, 0.05 \mathrm{mmol})$ was added to the solution mixture, and then the mixture was stirred at $25^{\circ} \mathrm{C}$ for $2 \mathrm{~h}$ under the $\mathrm{O}_{2}$ balloon ( $1 \mathrm{~atm}$ ). When conversion of alcohol to aldehyde was completed (monitored by TLC), the reaction mixture stirred under the $\mathrm{O}_{2}$ balloon $(1 \mathrm{~atm})$ at $80{ }^{\circ} \mathrm{C}$ for $10 \mathrm{~h}$ (without MOF filtration). The conversion ratios were checked for every $2 \mathrm{~h}$ by $\mathrm{GC}$.

Procedure for control experiment (b): benzyl alcohol (0.25 mmol), MOF-TEMPO (8 $\mathrm{mg}, 0.0125$ $\mathrm{mmol})$, and $\mathrm{CH}_{3} \mathrm{CN}(1 \mathrm{~mL})$ were added to a scintillation vial. tert-Butyl nitrite $(5 \mathrm{mg}, 0.05 \mathrm{mmol})$ was added to the solution mixture, and then the mixture was stirred at $25^{\circ} \mathrm{C}$ for $2 \mathrm{~h}$ under the $\mathrm{O}_{2}$ balloon (1 atm). When conversion of alcohol to aldehyde was completed (monitored by TLC), subsequently MOFTEMPO was removed by a syringe filter, and TEMPO was immediately added to the reaction mixture as a radical scavenger $(2 \mathrm{mg}, 0.0125 \mathrm{mmol})$. And the reaction mixture was stirred under the $\mathrm{O}_{2}$ balloon (1 atm) at $80^{\circ} \mathrm{C}$ for $10 \mathrm{~h}$. The conversion ratios were checked for every $2 \mathrm{~h}$ by GC.

Procedure for control experiment (c): benzyl alcohol $(0.25 \mathrm{mmol})$, MOF-TEMPO $(8 \mathrm{mg}, 0.0125 \mathrm{mmol})$, and $\mathrm{CH}_{3} \mathrm{CN}(1 \mathrm{~mL})$ were added to a scintillation vial. tert-Butyl nitrite $(5 \mathrm{mg}, 0.05 \mathrm{mmol})$ was added to the solution mixture, and then the mixture was stirred at $25^{\circ} \mathrm{C}$ for $2 \mathrm{~h}$ under the $\mathrm{O}_{2}$ balloon $(1 \mathrm{~atm})$. When conversion of alcohol to aldehyde was completed (monitored by TLC), subsequently MOFTEMPO was removed of by a syringe filter. Then the reaction stirred under the $\mathrm{O}_{2}$ balloon ( $\left.1 \mathrm{~atm}\right)$ at 80 ${ }^{\circ} \mathrm{C}$. After $2 \mathrm{~h}$, TEMPO was added to the reaction mixture as a radical scavenger $(2 \mathrm{mg}, 0.0125 \mathrm{mmol})$. And the reaction was stirred under the $\mathrm{O}_{2}$ balloon $(1 \mathrm{~atm})$ at $80^{\circ} \mathrm{C}$ for $10 \mathrm{~h}$. The conversion ratios were checked for every $2 \mathrm{~h}$ by GC.

Procedure for control experiment (d): benzyl alcohol $(0.25 \mathrm{mmol})$, MOF-TEMPO (8 $\mathrm{mg}, 0.0125$ $\mathrm{mmol})$, and $\mathrm{CH}_{3} \mathrm{CN}(1 \mathrm{~mL})$ were added to a scintillation vial. tert-Butyl nitrite $(5 \mathrm{mg}, 0.05 \mathrm{mmol})$ was added to the solution mixture, and then the mixture was stirred at $25^{\circ} \mathrm{C}$ for $2 \mathrm{~h}$ under the $\mathrm{O}_{2}$ balloon (1 atm). When conversion of alcohol to aldehyde was completed (monitored by TLC), subsequently MOFTEMPO was removed by a syringe filter. Then the reaction was stirred under the $\mathrm{O}_{2}$ balloon (1 atm) at $80^{\circ} \mathrm{C}$. After $4 \mathrm{~h}$, MOF-TEMPO was added $(8 \mathrm{mg}, 0.0125 \mathrm{mmol})$ to the reaction mixture. And the reaction was stirred under the $\mathrm{O}_{2}$ balloon ( $1 \mathrm{~atm}$ ) at $80^{\circ} \mathrm{C}$ for $10 \mathrm{~h}$. The conversion ratios were checked for every $2 \mathrm{~h}$ by $\mathrm{GC}$.

Procedure for control experiment (e): benzyl alcohol ( $0.25 \mathrm{mmol})$, MOF-TEMPO $(8 \mathrm{mg}, 0.0125 \mathrm{mmol})$, and $\mathrm{CH}_{3} \mathrm{CN}(1 \mathrm{~mL})$ were added to a scintillation vial. tert-Butyl nitrite $(5 \mathrm{mg}, 0.05 \mathrm{mmol})$ was added to the solution mixture, and then the mixture was stirred at $25^{\circ} \mathrm{C}$ for $2 \mathrm{~h}$ under the $\mathrm{O}_{2}$ balloon $(1 \mathrm{~atm})$. When conversion of alcohol to aldehyde was completed (monitored by TLC), subsequently MOF- 
TEMPO was removed by a syringe filter. Then the reaction stirred under the $\mathrm{O}_{2}$ balloon ( $\left.1 \mathrm{~atm}\right)$ at 80 ${ }^{\circ} \mathrm{C}$. After $4 \mathrm{~h}$, MOF-TEMPO ( $8 \mathrm{mg}, 0.0125 \mathrm{mmol}$ ) was added to the reaction mixture. And the reaction was stirred under the $\mathrm{O}_{2}$ balloon ( $1 \mathrm{~atm}$ ) at $80^{\circ} \mathrm{C}$ for $4 \mathrm{~h}$ followed by filtration to remove MOF-TEMPO. Then the reaction was stirred under the $\mathrm{O}_{2}$ balloon ( $1 \mathrm{~atm}$ ) at $80^{\circ} \mathrm{C}$ for $6 \mathrm{~h}$. The conversion ratios were checked for every $2 \mathrm{~h}$ by GC.

Procedure for control experiment (f): benzyl alcohol (0.25 mmol), MOF-TEMPO ( $8 \mathrm{mg}, 0.0125 \mathrm{mmol})$, and $\mathrm{CH}_{3} \mathrm{CN}(1 \mathrm{~mL})$ were added to a scintillation vial. tert-Butyl nitrite $(5 \mathrm{mg}, 0.05 \mathrm{mmol})$ was added to the solution mixture, and then the mixture was stirred at $25^{\circ} \mathrm{C}$ for $1 \mathrm{~h}$ (half of the standard condition) under the $\mathrm{O}_{2}$ balloon ( $1 \mathrm{~atm}$ ), subsequently MOF-TEMPO was removed by a syringe filter. Then the mixture of alcohol and aldehyde was stirred under the $\mathrm{O}_{2}$ balloon (1 atm) at $80{ }^{\circ} \mathrm{C}$ for $10 \mathrm{~h}$. The conversion ratios were checked for every $2 \mathrm{~h}$ by GC.

Procedure for control experiment $(\mathbf{h})$ : benzyl alcohol $(0.25 \mathrm{mmol})$, MOF-TEMPO (8 $\mathrm{mg}, 0.0125$ $\mathrm{mmol})$, and $\mathrm{CH}_{3} \mathrm{CN}(1 \mathrm{~mL})$ were added to a scintillation vial. tert-Butyl nitrite $(5 \mathrm{mg}, 0.05 \mathrm{mmol})$ was added to the solution mixture, and then the mixture was stirred at $25^{\circ} \mathrm{C}$ for $2 \mathrm{~h}$ under the $\mathrm{O}_{2}$ balloon (1 atm). When conversion of alcohol to aldehyde was completed (monitored by TLC), subsequently MOFTEMPO was removed by a syringe filter, and tert-butyl alcohol was immediately added to the reaction mixture as a radical scavenger $(4 \mathrm{mg}, 0.050 \mathrm{mmol})$. And the reaction mixture was stirred under the $\mathrm{O}_{2}$ balloon (1 atm) at $80^{\circ} \mathrm{C}$ for $10 \mathrm{~h}$. The conversion ratios were checked for every $2 \mathrm{~h}$ by GC.

Procedure for control experiment $(\mathbf{g})$ : benzyl alcohol $(0.25 \mathrm{mmol})$, MOF-TEMPO (8 $\mathrm{mg}, 0.0125$ mmol), and $\mathrm{CH}_{3} \mathrm{CN}(1 \mathrm{~mL})$ were added to a scintillation vial. tert-Butyl nitrite $(5 \mathrm{mg}, 0.05 \mathrm{mmol})$ was added to the solution mixture, and then the mixture was stirred at $25^{\circ} \mathrm{C}$ for $2 \mathrm{~h}$ under the $\mathrm{O}_{2}$ balloon (1 atm). When conversion of alcohol to aldehyde was completed (monitored by TLC), subsequently MOFTEMPO was removed by a syringe filter. Then the reaction was stirred under the $\mathrm{N}_{2}$ balloon (1 atm) at $80^{\circ} \mathrm{C}$ for $10 \mathrm{~h}$. The conversion ratios were checked for every $2 \mathrm{~h}$ by GC.

Procedure for control experiment (i): benzyl alcohol ( $0.25 \mathrm{mmol})$, MOF-TEMPO (8 mg, $0.0125 \mathrm{mmol})$, and $\mathrm{CH}_{3} \mathrm{CN}(1 \mathrm{~mL})$ were added to a scintillation vial. tert-Butyl nitrite $(5 \mathrm{mg}, 0.05 \mathrm{mmol})$ was added to the solution mixture, and then the mixture was stirred at $25^{\circ} \mathrm{C}$ for $2 \mathrm{~h}$ under the $\mathrm{O}_{2}$ balloon (1 atm). When conversion of alcohol to aldehyde was completed (monitored by TLC), subsequently MOFTEMPO was removed by a syringe filter. Then the reaction stirred under the $\mathrm{O}_{2}$ balloon $(1 \mathrm{~atm})$ at 80 ${ }^{\circ} \mathrm{C}$. After $2 \mathrm{~h}$, the $\mathrm{O}_{2}$ balloon (1 atm) was replaced with the $\mathrm{N}_{2}$ balloon $(1 \mathrm{~atm})$ and then the reaction stirred at $80^{\circ} \mathrm{C}$ for $10 \mathrm{~h}$. The conversion ratios were checked for every $2 \mathrm{~h}$ by GC. 


\section{Procedures for in-situ NMR Experiments of the Second Step}

in-situ NMR experiment 1: alcohol reagent (0.25 mmol), MOF-TEMPO (8 $\mathrm{mg}, 0.0125 \mathrm{mmol})$, and $\mathrm{CD}_{3} \mathrm{CN}(1 \mathrm{~mL})$ were added to a scintillation vial. tert-Butyl nitrite $(5 \mathrm{mg}, 0.05 \mathrm{mmol})$ was added to the solution mixture, and then the mixture was stirred at $25{ }^{\circ} \mathrm{C}$ for $2 \mathrm{~h}$ under the $\mathrm{O}_{2}$ balloon $(1 \mathrm{~atm})$. The reaction was monitored by TLC (thin-layer chromatography). When conversion of alcohol to aldehyde was complete (by TLC monitoring), subsequently MOF-TEMPO was recovered from the reaction mixture by a syringe filter. Approximately $2 \times 0.25 \mathrm{~mL}$ of $\mathrm{CD}_{3} \mathrm{CN}$ was used to prevent the loss of the yield. Then the reaction mixture was stirred for the second step under the $\mathrm{O}_{2}$ balloon ( $\left.1 \mathrm{~atm}\right)$ at $80^{\circ} \mathrm{C}$. The behavior of each compound hourly was observed by in-situ NMR.

in-situ NMR experiment 2: tert-Butyl nitrite $(20 \mathrm{mg}, 0.20 \mathrm{mmol})$ and $\mathrm{CD}_{3} \mathrm{CN}(1 \mathrm{~mL})$ were added to a scintillation vial and then the mixture was stirred at $80{ }^{\circ} \mathrm{C}$ under the $\mathrm{O}_{2}$ balloon ( $1 \mathrm{~atm}$ ). The behavior of each compound hourly was observed by in-situ NMR.

\section{Procedures for in-situ NMR Experiments of Radical Trapping with NHC-Carbene}

in-situ NMR experiment for radical trapping 1: tert-Butyl nitrite (20 mg, $0.19 \mathrm{mmol}$ ) and benzene- $d_{6}$ $(0.5 \mathrm{~mL})$ were added to a scintillation vial and then the mixture was stirred at $25{ }^{\circ} \mathrm{C}$ for $5 \mathrm{~h}$ under the $\mathrm{O}_{2}$ balloon (1 atm) and cooled to $0^{\circ} \mathrm{C}$ under $\mathrm{N}_{2}(\mathrm{~g})$. In a $\mathrm{N}_{2}$ atmosphere glovebox, a solution of 1,3-bis(2,6-diisopropylphenyl)imidazolylidene (IPr, $20 \mathrm{mg}, 0.051 \mathrm{mmol})$ in benzene- $d_{6}(0.5 \mathrm{~mL})$ in a sealed 4 $\mathrm{mL}$ vial with a cap fitted with a Teflon-lined septum was prepared, taken out of the glove box, and added to the reaction mixture. The dark red solution was observed by in-situ NMR.

in-situ NMR experiment for radical trapping 2: tert-Butyl nitrite $(20 \mathrm{mg}, 0.19 \mathrm{mmol})$ and benzene-d6 $(0.5 \mathrm{~mL})$ were added to a scintillation vial and then the mixture was stirred at $80{ }^{\circ} \mathrm{C}$ for $5 \mathrm{~h}$ under the $\mathrm{O}_{2}$ balloon ( $1 \mathrm{~atm}$ ) and cooled to $0{ }^{\circ} \mathrm{C}$ under $\mathrm{N}_{2}(\mathrm{~g})$. In a $\mathrm{N}_{2}$ atmosphere glovebox, a solution of 1,3-bis(2,6-diisopropylphenyl)imidazolylidene (IPr, $20 \mathrm{mg}, 0.051 \mathrm{mmol})$ in benzene- $d_{6}(0.5 \mathrm{~mL})$ in a sealed 4 $\mathrm{mL}$ vial with a cap fitted with a Teflon-lined septum was prepared, taken out of the glove box, and added to the reaction mixture. The light yellow solution was observed by in-situ NMR. 


\section{Procedures and Method for EPR Experiments}

General Method: X-band CW-EPR spectra were recorded with the following experimental parameters: microwave frequency, $9.4 \mathrm{GHz}$; microwave power, $1 \mathrm{~mW}$; modulation amplitude, $1 \mathrm{G}$; modulation frequency, $100 \mathrm{kHz}$; time constant, $0.01 \mathrm{~ms}$; temperature, $296 \mathrm{~K}$.

Sample \#1: tert-Butyl nitrite $(20 \mathrm{mg}, 0.19 \mathrm{mmol})$ and benzene- $d_{6}(0.5 \mathrm{~mL})$ were added to a scintillation vial and then the mixture was stirred at $25{ }^{\circ} \mathrm{C}$ for $5 \mathrm{~h}$ under the $\mathrm{O}_{2}$ balloon $\left(1 \mathrm{~atm}\right.$ ) and cooled to $0{ }^{\circ} \mathrm{C}$ under $\mathrm{N}_{2}$ (g). In a $\mathrm{N}_{2}$ atmosphere glovebox, a solution of 1,3-bis-(2,6-diisopropylphenyl)imidazolylidene (IPr, $20 \mathrm{mg}, 0.051 \mathrm{mmol})$ in benzene- $d_{6}(0.5 \mathrm{~mL})$ in a sealed $4 \mathrm{~mL}$ vial with a cap fitted with a Teflonlined septum was prepared, taken out of the glove box, and added to the reaction mixture. The dark red solution was diluted in benzene and the solution was transferred into an EPR tube. The EPR spectrum of the sample was obtained at $23^{\circ} \mathrm{C}$.

Sample \#2: tert-Butyl nitrite $(20 \mathrm{mg}, 0.19 \mathrm{mmol})$ and benzene- $d_{6}(0.5 \mathrm{~mL})$ were added to a scintillation vial and then the mixture was stirred at $80^{\circ} \mathrm{C}$ for $5 \mathrm{~h}$ under the $\mathrm{O}_{2}$ balloon $\left(1 \mathrm{~atm}\right.$ ) and cooled to $0{ }^{\circ} \mathrm{C}$ under $\mathrm{N}_{2}$ (g). In a $\mathrm{N}_{2}$ atmosphere glovebox, a solution of 1,3-bis-(2,6-diisopropylphenyl)imidazolylidene $(I P r, 20 \mathrm{mg}, 0.051 \mathrm{mmol})$ in benzene- $d_{6}(0.5 \mathrm{~mL})$ in a sealed $4 \mathrm{~mL}$ vial with a cap fitted with a Teflonlined septum was prepared, taken out of the glove box, and added to reaction mixture. The light yellow solution was diluted in benzene and the solution was transferred into an EPR tube. The EPR spectrum of the sample was obtained at $23^{\circ} \mathrm{C}$.

\section{Procedure for Reusability Test}

Procedure for Reusability Test with Gram Scale: benzyl alcohol (1.1 g, $10 \mathrm{mmol})$, MOF-TEMPO (320 $\mathrm{mg}, 0.5 \mathrm{mmol})$, and $\mathrm{CH}_{3} \mathrm{CN}(8 \mathrm{~mL})$ were added to a a scintillation vial $(20 \mathrm{~mL})$. tert-Butyl nitrite $(200 \mathrm{mg}$, $2.0 \mathrm{mmol}$ ) was added to the solution mixture and then the mixture was stirred at $25{ }^{\circ} \mathrm{C}$ under the $\mathrm{O}_{2}$ balloon (1 atm). When conversion of alcohol to aldehyde was completed (monitored by TLC), subsequently MOF-TEMPO was recovered by centrifugation and filtration. Then the reaction stirred under the $\mathrm{O}_{2}$ balloon at $80^{\circ} \mathrm{C}$ for $10 \mathrm{~h}$. After completion, the desired product was isolated by a silica gel column chromatography with EtOAc/n-hexane $(1 / 30$ to $1 / 2, \mathrm{v} / \mathrm{v})$ as the eluent. The recovered MOFTEMPO was used again to the sequential oxidation reactions after drying (re-activation) under vacuum. [CAUTION] The high pressure of $\mathrm{O}_{2}(\mathrm{~g})$ and the large-scale experiments with $\mathrm{O}_{2}(\mathrm{~g})$ can cause a fire. 
Table S1. Optimization of the reaction conditions for MOF-TEMPO in-and-out methoda.

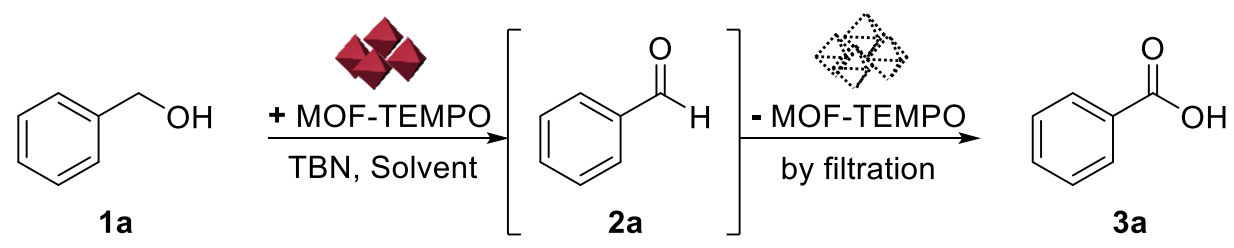

\begin{tabular}{|c|c|c|c|}
\hline \multirow{2}{*}{ entry } & \multirow{2}{*}{ solvent } & \multicolumn{3}{|c|}{ conv. $(\%)^{b}$} \\
\cline { 3 - 4 } & & $\mathbf{2 a}$ & $\mathbf{3 a}$ \\
\hline 1 & $\mathrm{CH}_{3} \mathrm{CN}$ & 3 & $97(96)^{c}$ \\
\hline $2^{d}$ & $\mathrm{CH}_{3} \mathrm{CN}$ & 99 & n.r. \\
\hline $3^{e}$ & $\mathrm{CH}_{3} \mathrm{CN}$ & 99 & n.r. \\
\hline $4^{f}$ & $\mathrm{CH}_{3} \mathrm{CN}$ & 99 & n.r. \\
\hline $5^{g}$ & $1,2-\mathrm{DCE}$ & 99 & n.r. \\
\hline 6 & $1,2-\mathrm{DCE}$ & 17 & 83 \\
\hline $7^{h}$ & $\mathrm{EA}$ & 45 & n.r. \\
\hline $8^{h}$ & toluene & 58 & n.r. \\
\hline $9^{h}$ & $\mathrm{H}_{2} \mathrm{O}$ & 8 & n.r. \\
\hline $10^{h}$ & $1,4-d i o x a n e$ & 70 & n.r. \\
\hline 11 & Anhydrous & $<1$ & 90 \\
\hline
\end{tabular}

aReaction conditions: $1 \mathrm{a}(0.5 \mathrm{mmol}, 54 \mathrm{mg})$, MOF-TEMPO $(0.025 \mathrm{mmol}, 16 \mathrm{mg})$, TBN $(0.1 \mathrm{mmol})$, solvent $(1 \mathrm{~mL})$ were used. The reaction was stirred under an $\mathrm{O}_{2}$ balloon at $25{ }^{\circ} \mathrm{C}$ for $2 \mathrm{~h}$, followed by filtration of MOF-TEMPO and stirring under an $\mathrm{O}_{2}$ balloon at $80^{\circ} \mathrm{C}$ for $10 \mathrm{~h} . ;{ }^{b} \mathrm{GC}$ conversion; n.r. = no reaction. cIsolated yield.; ${ }^{d}$ After filtration of MOF-TEMPO, stirred in $\mathrm{O}_{2}$ balloon at $25^{\circ} \mathrm{C}$ for $10 \mathrm{~h}$.; ${ }^{\mathrm{e}}$ After filtration of MOF-TEMPO, stirred in $\mathrm{O}_{2}$ balloon at $40^{\circ} \mathrm{C}$ for $10 \mathrm{~h}$.; fAfter filtration of MOF-TEMPO, stirred in $\mathrm{O}_{2}$ balloon at $60{ }^{\circ} \mathrm{C}$ for $10 \mathrm{~h}$.; 9 No MOF-TEMPO filtration.; ${ }^{h}$ The reaction was stirred in $\mathrm{O}_{2}$ balloon at $25^{\circ} \mathrm{C}$ for $2 \mathrm{~h}$. 
Table S2. Optimization of the reaction conditions for autoxidation of benzaldehyde (2a) to benzoic acid $(3 \mathbf{a})^{a}$

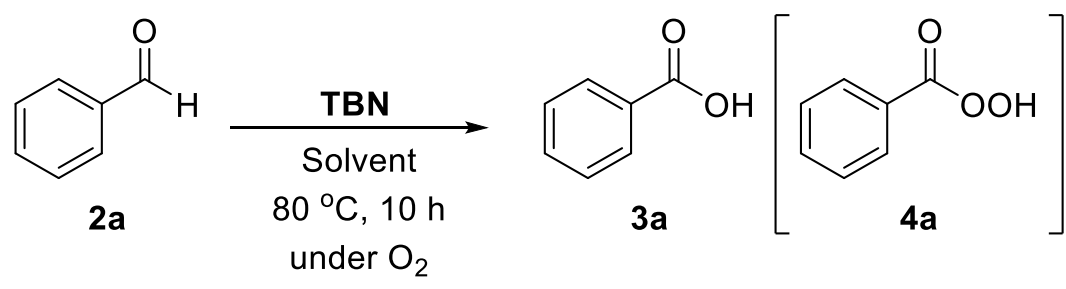

\begin{tabular}{|c|c|c|c|c|}
\hline \multirow{2}{*}{ entry } & \multirow{2}{*}{ TBN } & \multirow{2}{*}{ solvent } & \multicolumn{2}{|c|}{${\text { conv. }(\%)^{b}}^{b}$} \\
\cline { 4 - 5 } & & & $\mathbf{2 a}$ & $\mathbf{3 a}$ \\
\hline $1^{c, d}$ & $\mathrm{X}$ & $\mathrm{CH}_{3} \mathrm{CN}$ & 55 & 17 \\
\hline 2 & $\mathrm{X}$ & $\mathrm{CH}_{3} \mathrm{CN}$ & 94 & n.r. \\
\hline 3 & $\mathrm{O}$ & $\mathrm{CH}_{3} \mathrm{CN}$ & 95 & n.r. \\
\hline 4 & $\mathrm{O}$ & $\mathrm{DCE}$ & 83 & n.r. \\
\hline 5 & $\mathrm{O}$ & $\mathrm{EA}$ & 82 & n.r. \\
\hline 6 & $\mathrm{O}$ & toluene & 5 & n.r. \\
\hline 7 & $\mathrm{O}$ & $\mathrm{H}_{2} \mathrm{O}$ & 39 & n.r. \\
\hline 8 & $\mathrm{O}$ & 1,4-dioxane & 80 & n.r. \\
\hline
\end{tabular}

aReaction conditions: $1 \mathrm{a}(0.5 \mathrm{mmol}, 54 \mathrm{mg})$, TBN $(0.1 \mathrm{mmol})$, solvent $(1 \mathrm{~mL})$ were used. The reaction was stirred in $\mathrm{O}_{2}$ balloon at $80^{\circ} \mathrm{C}$ for $10 \mathrm{~h}$.; ${ }^{b} \mathrm{GC}$ conversion; n.r. = no reaction ${ }^{c}$ The reaction was stirred in $\mathrm{O}_{2}$ balloon at $60^{\circ} \mathrm{C}$ for $10 \mathrm{~h}$.; ${ }^{d} \mathrm{NMR}$ yield with mesitylene as internal standard. 


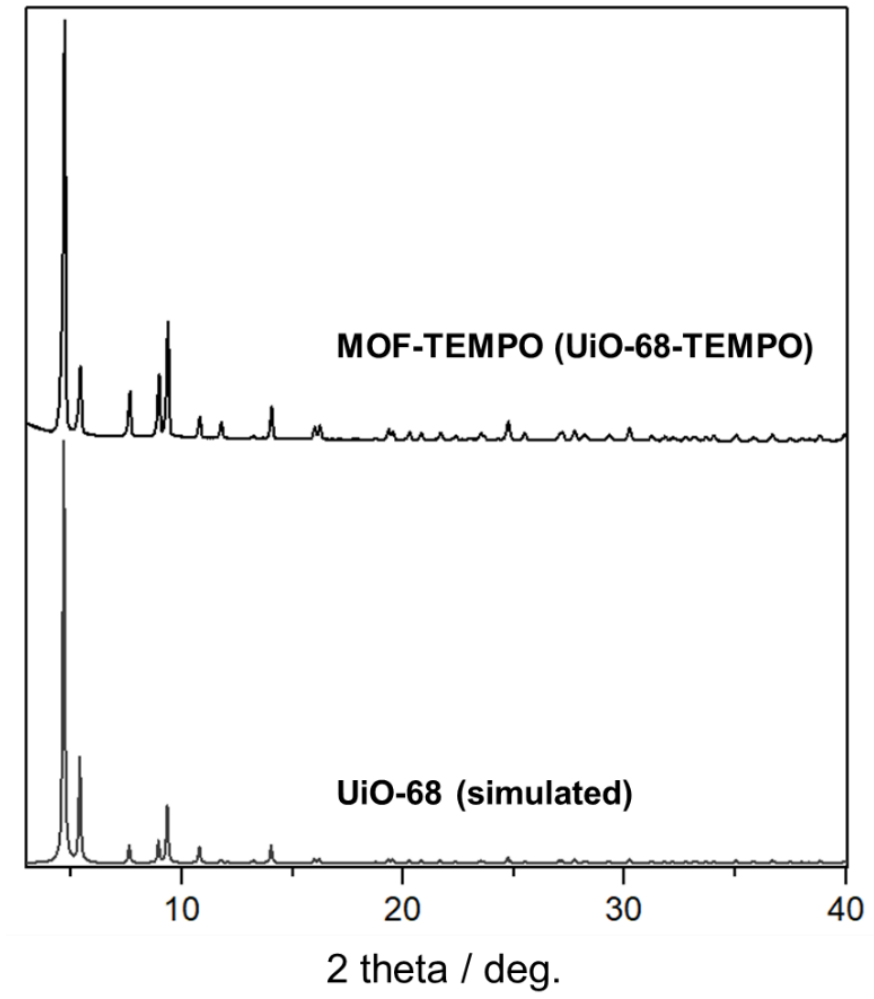

Figure S1. PXRD of as-synthesized MOF-TEMPO (UiO-68-TEMPO). 

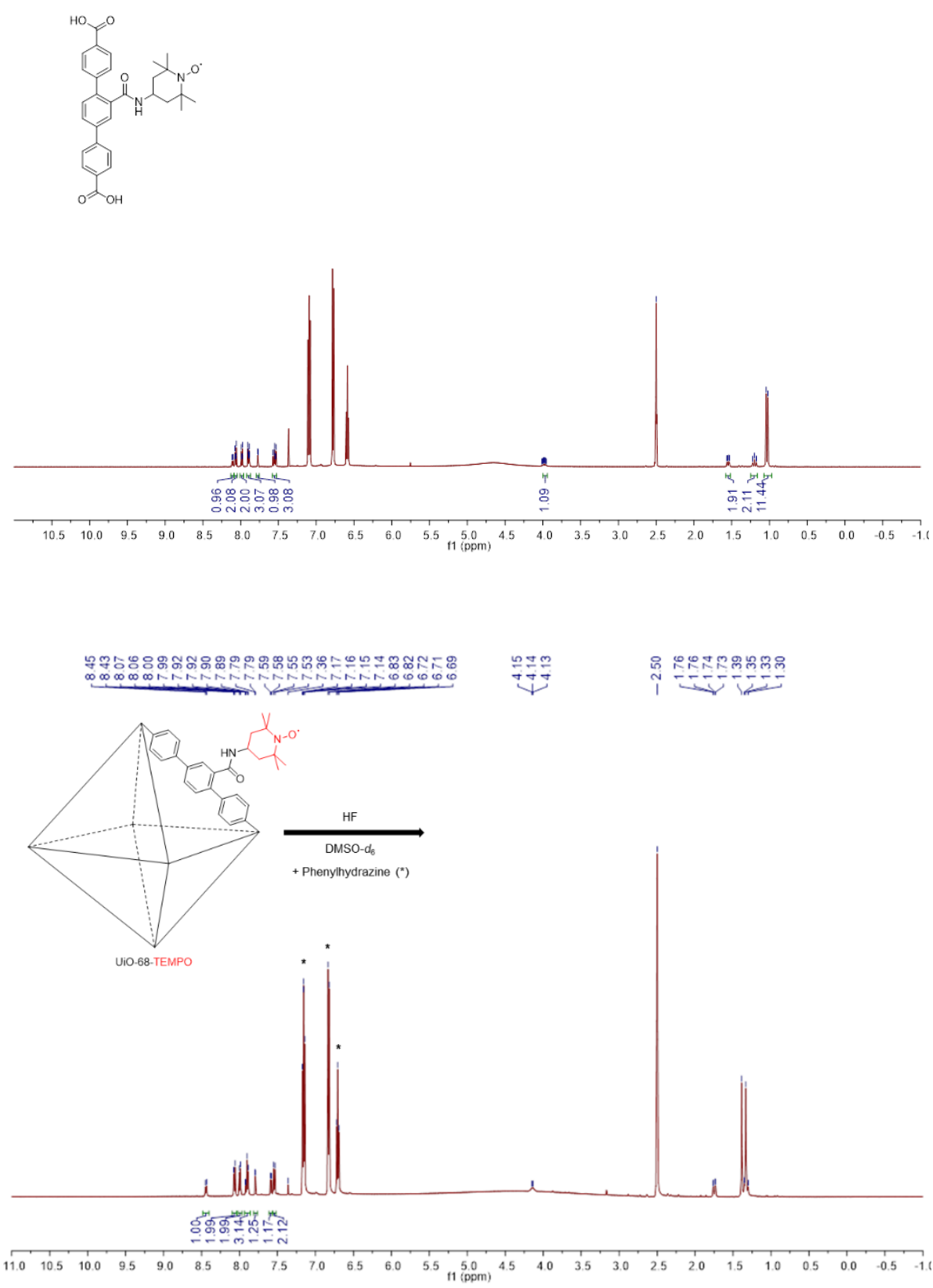

Figure S2. ${ }^{1} \mathrm{H}$ NMR spectra of TPDC-TEMPO (top) and MOF-TEMPO (bottom) after acid digestion. Phenylhydrazine is reducing agent for the paramagnetic nitroxide radicals to the corresponding hydroxylamine. 

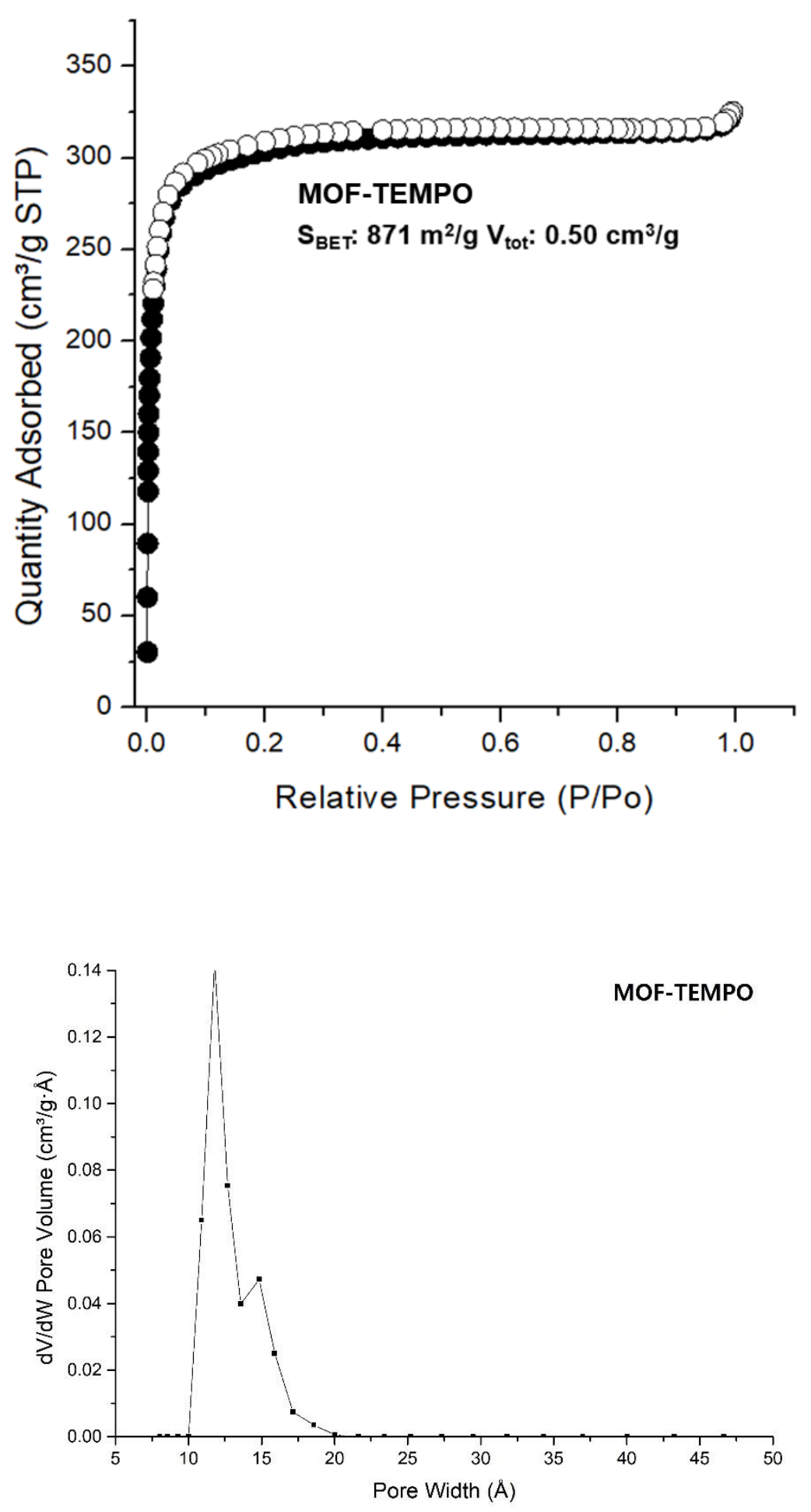

Figure S3. $\mathrm{N}_{2}$ full isotherm of activated MOF-TEMPO (UiO-68-TEMPO, top), and pore size distribution analysis through the NLDFT model of MOF-TEMPO (bottom). 

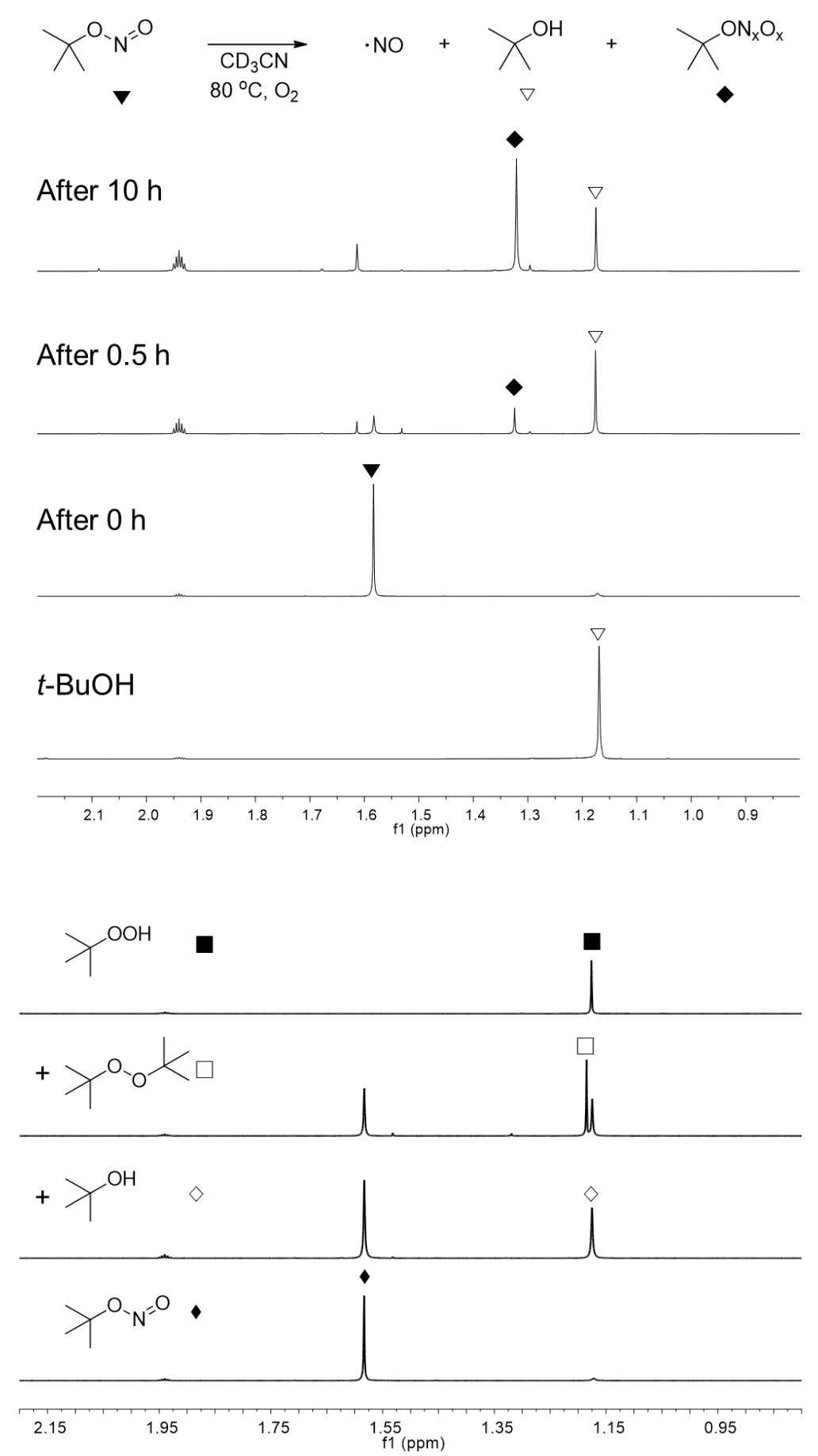

Figure S4. in-situ ${ }^{1} \mathrm{H}$ NMR spectrum of the reaction mixture with tert-butyl nitrite in $\mathrm{CD}_{3} \mathrm{CN}$ under heating at $80{ }^{\circ} \mathrm{C}$ for $10 \mathrm{~h}$ (top), authentic ${ }^{1} \mathrm{H}$ NMR for commercially available tert-butyl containing compounds (bottom). 


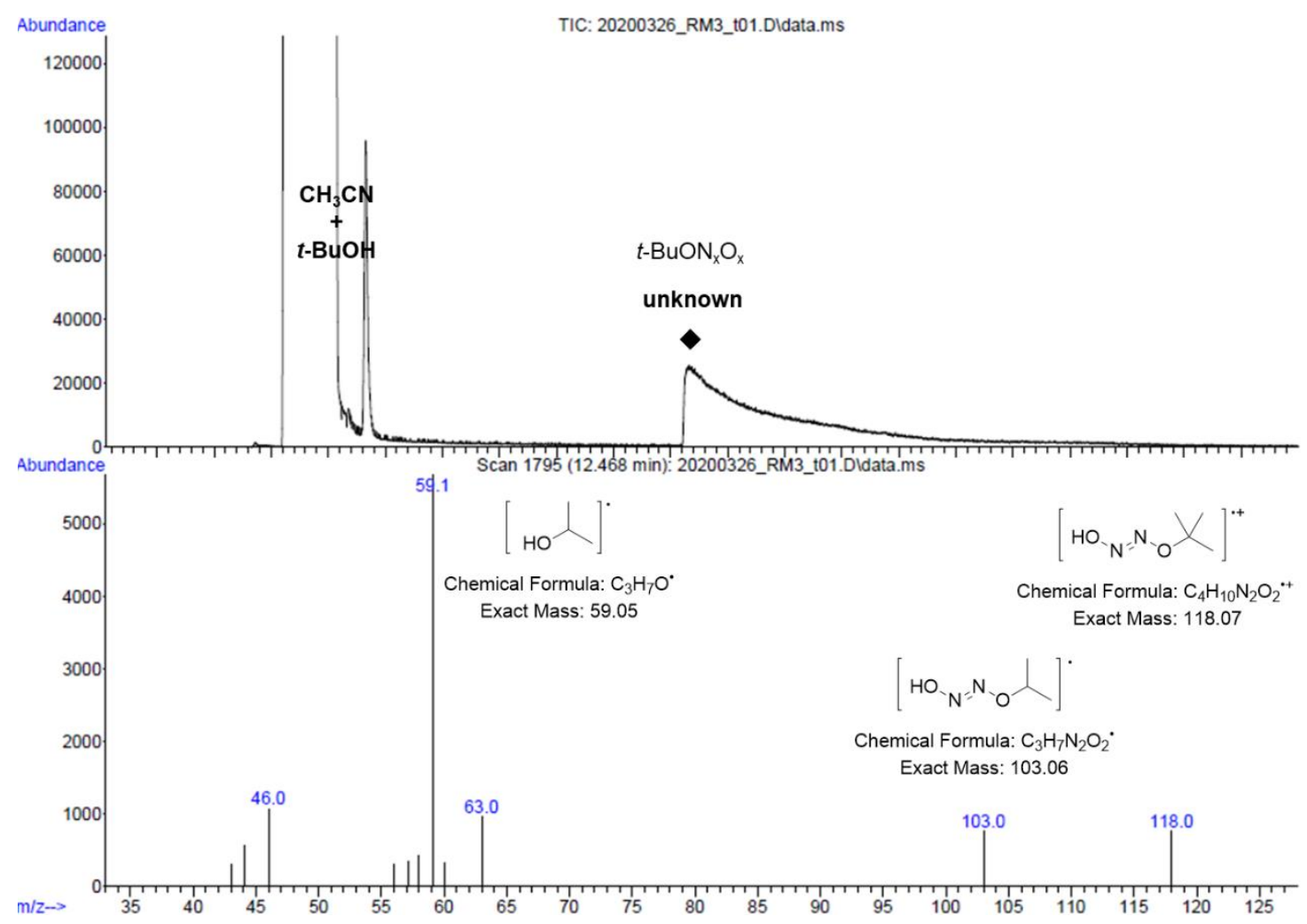

Figure S5. Gas chromatography-mass spectrometry (GC-MS) analysis for the reaction mixture of tertbutyl nitrite under heating at $80^{\circ} \mathrm{C}$ for $10 \mathrm{~h}$. 


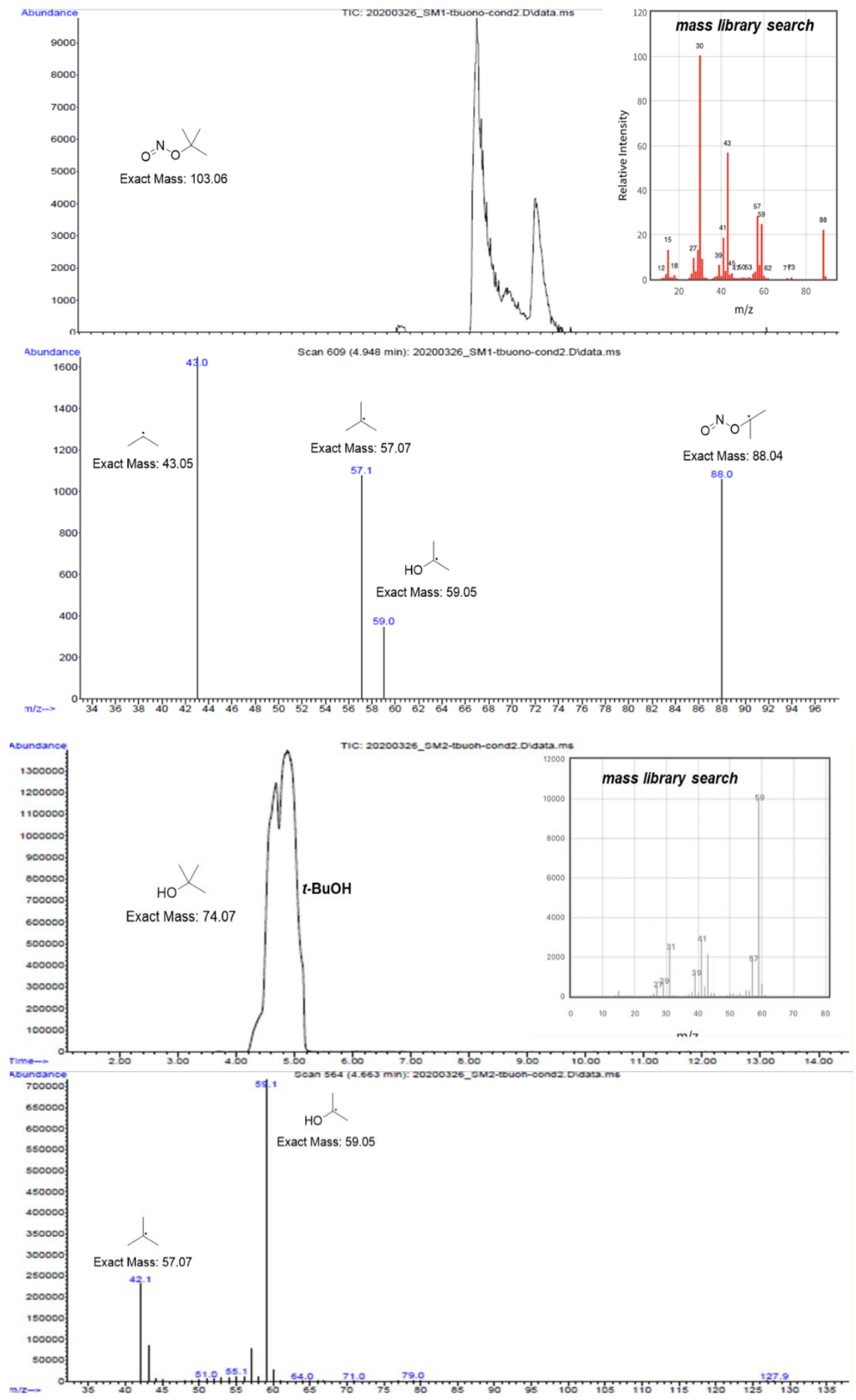

Figure S6. Gas chromatography-mass spectrometry (GC-MS) analysis of tert-butyl nitrite (top) and tert-butyl alcohol (bottom). 


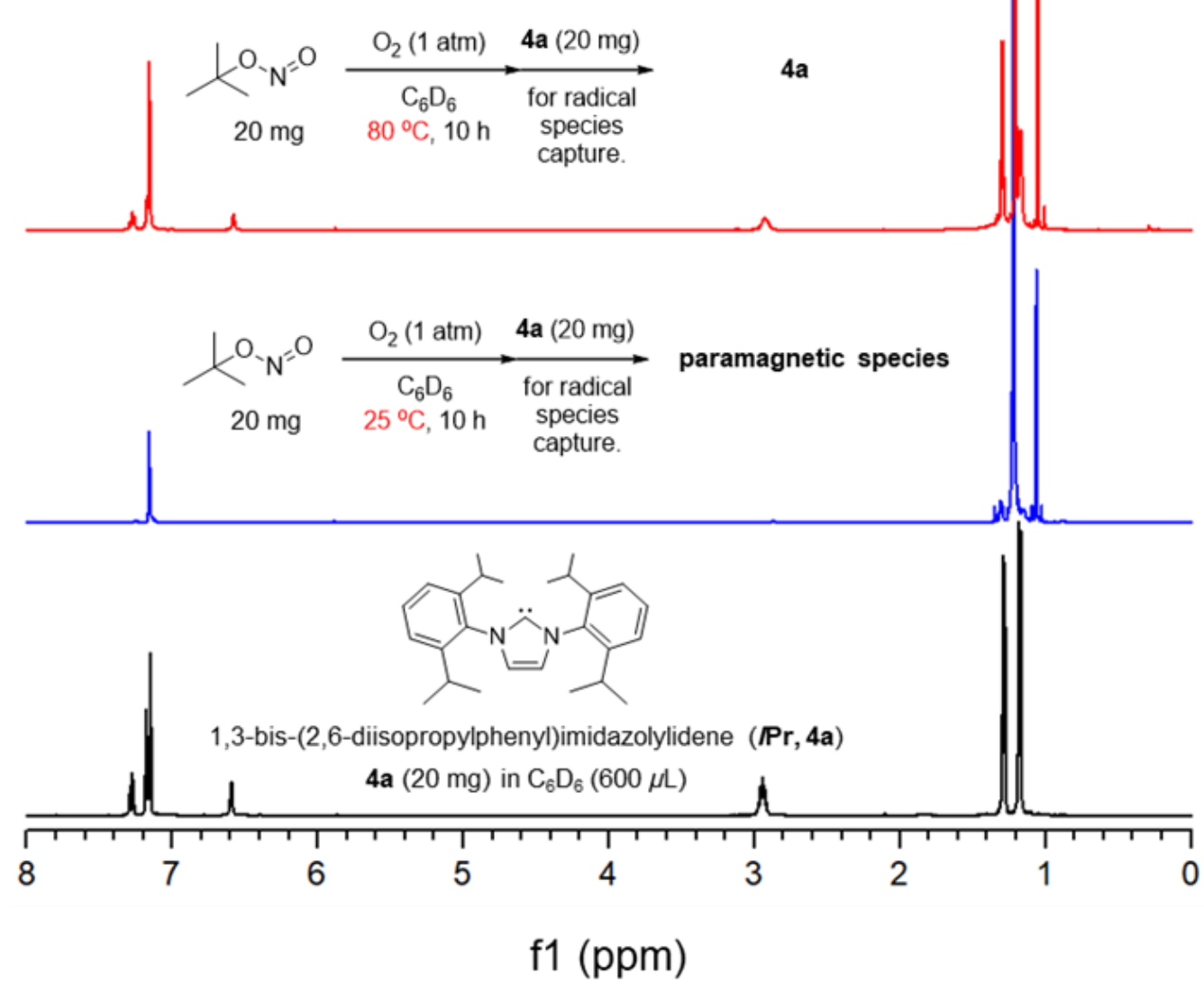

Figure S7. In-situ NMR Spectra of TBN + N-heterocyclic-carbene. 


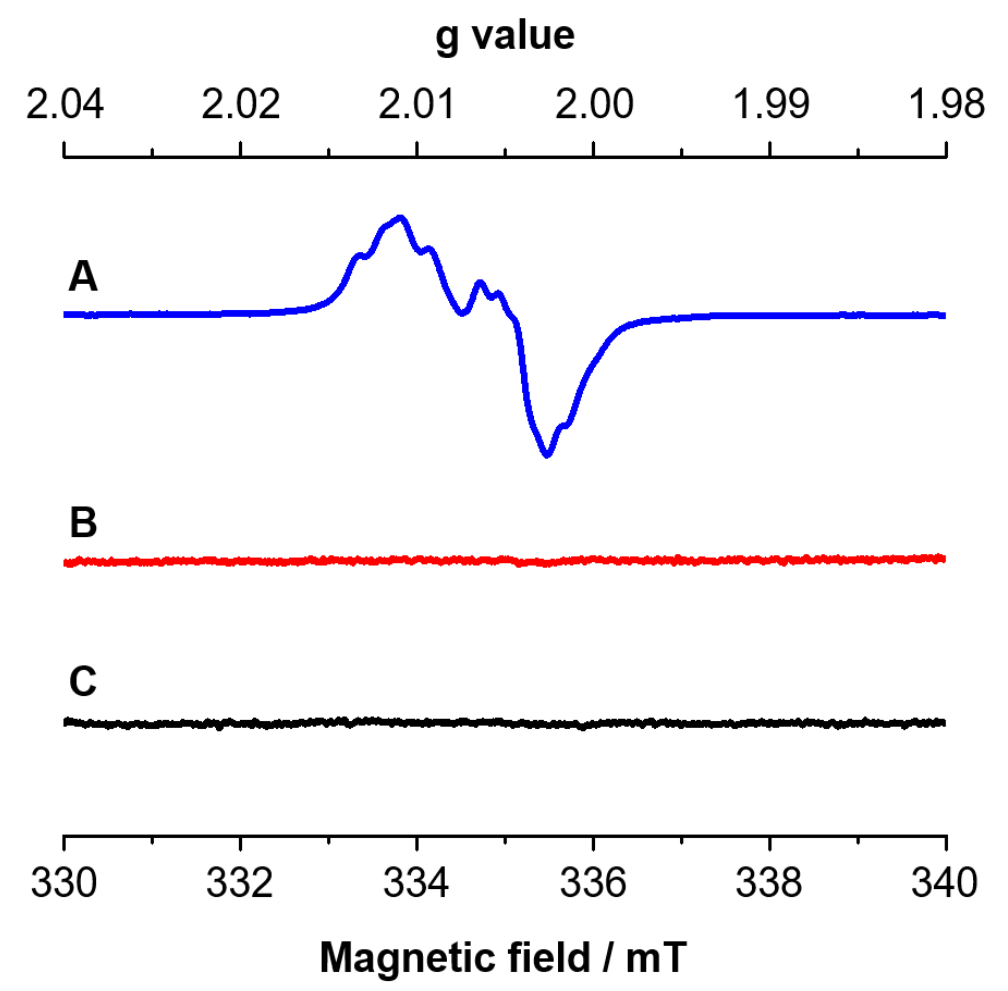

Figure S8. X-band CW-EPR spectra of sample \#1 (A), sample \#2 (B), and $I \operatorname{Pr}(C)$ in benzene-d6. 


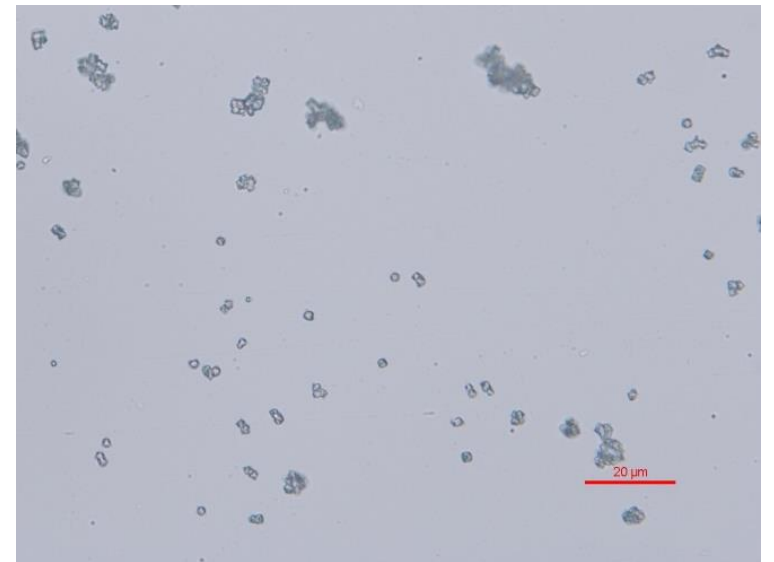

Microscope image of MOF-TEMPO (before reaction)

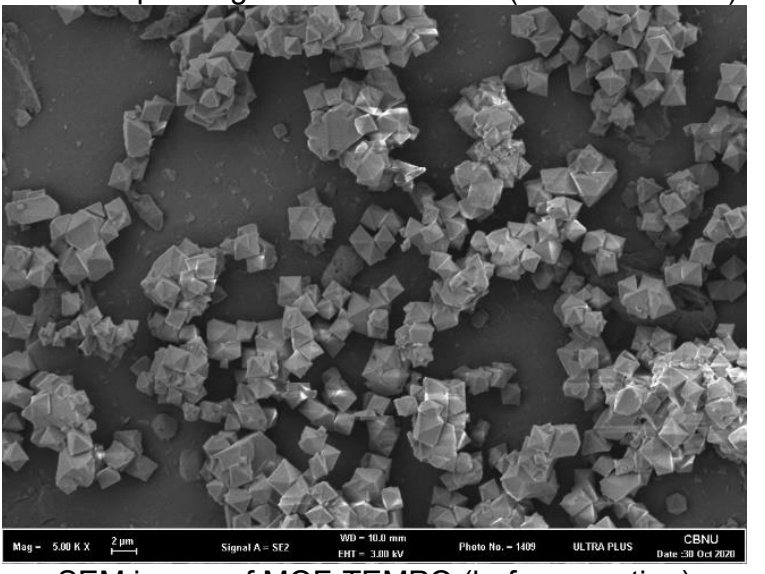

SEM image of MOF-TEMPO (before reaction)

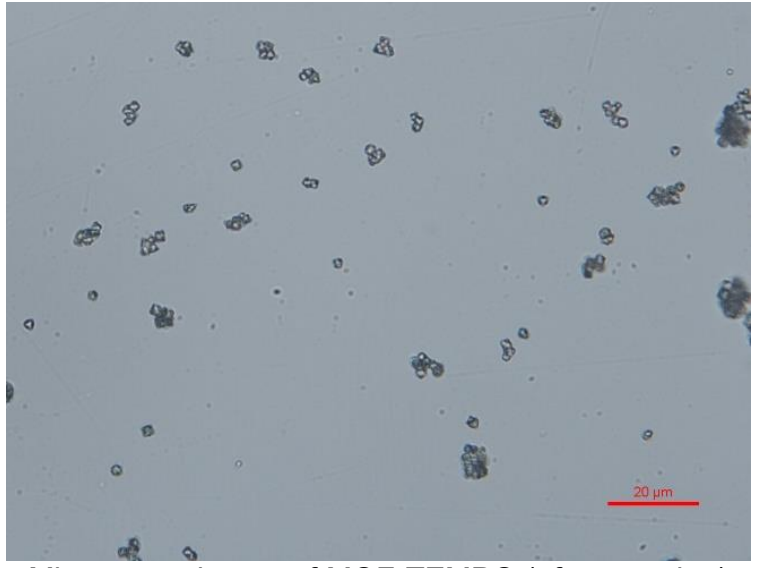

Microscope image of MOF-TEMPO (after reaction)

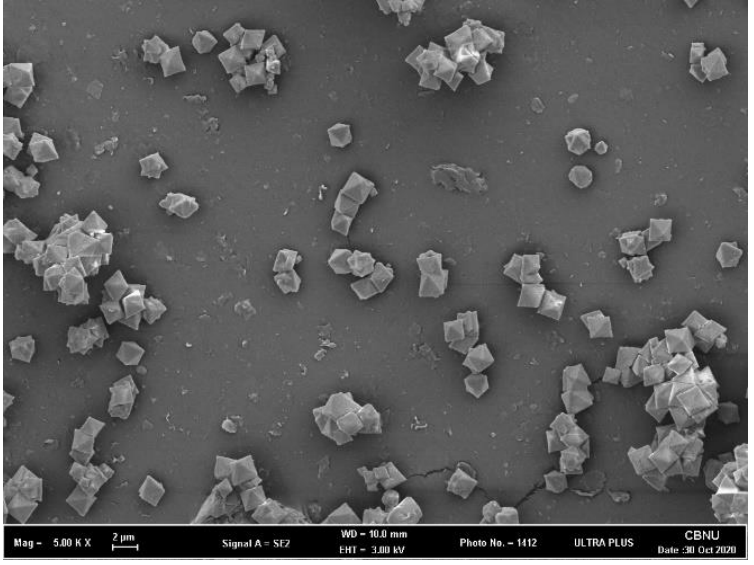

SEM image of MOF-TEMPO (after reaction)

Figure S9. Microscope and SEM images of MOF-TEMPO (before and after oxidation reaction). 


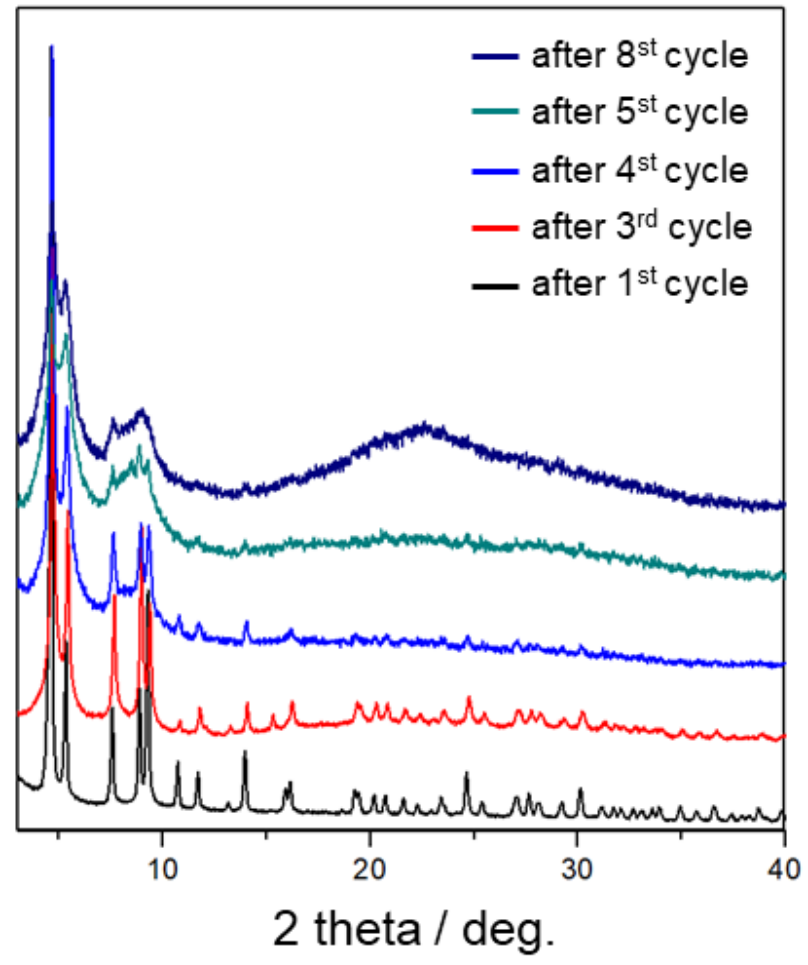

Figure S10. PXRD patterns of the recovered MOF-TEMPO from oxidation. 
Scheme S1. Proposed TBN mechanism in details including reported STEP I, S8, S9 STEP II, ${ }^{\text {S10-12 STEP }}$ IIIS13-16

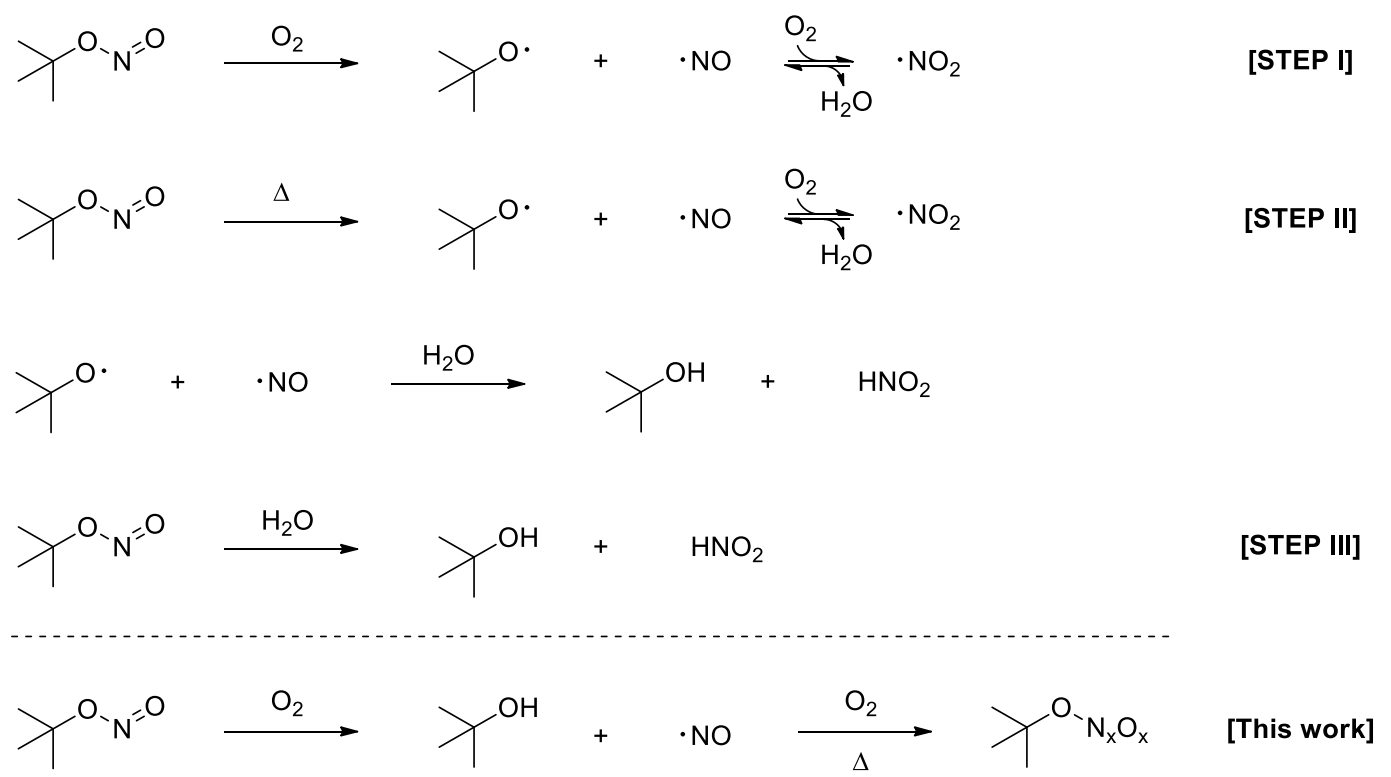




\section{Appendix}

Spectral Copies of ${ }^{1} \mathrm{H}$ and ${ }^{13} \mathrm{C}$ NMR of the Obtained Compounds 
TPDCE-TEMPO (500 MHz for ${ }^{1} \mathrm{H}$ and $125 \mathrm{MHz}$ for ${ }^{13} \mathrm{C}\left\{{ }^{1} \mathrm{H}\right\}$ in DMSO- $d_{6}$ )
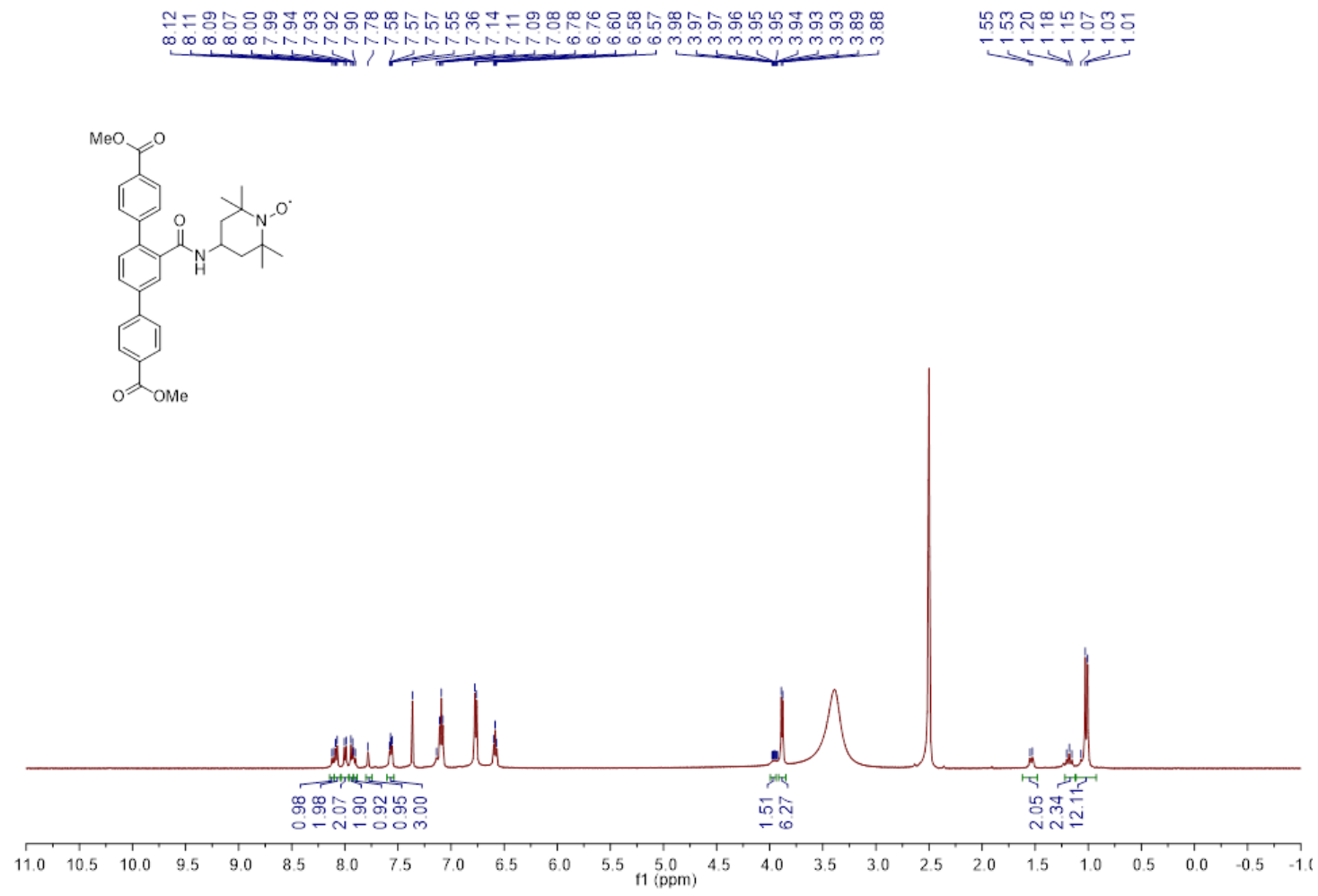

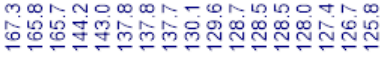

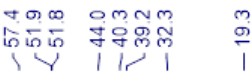
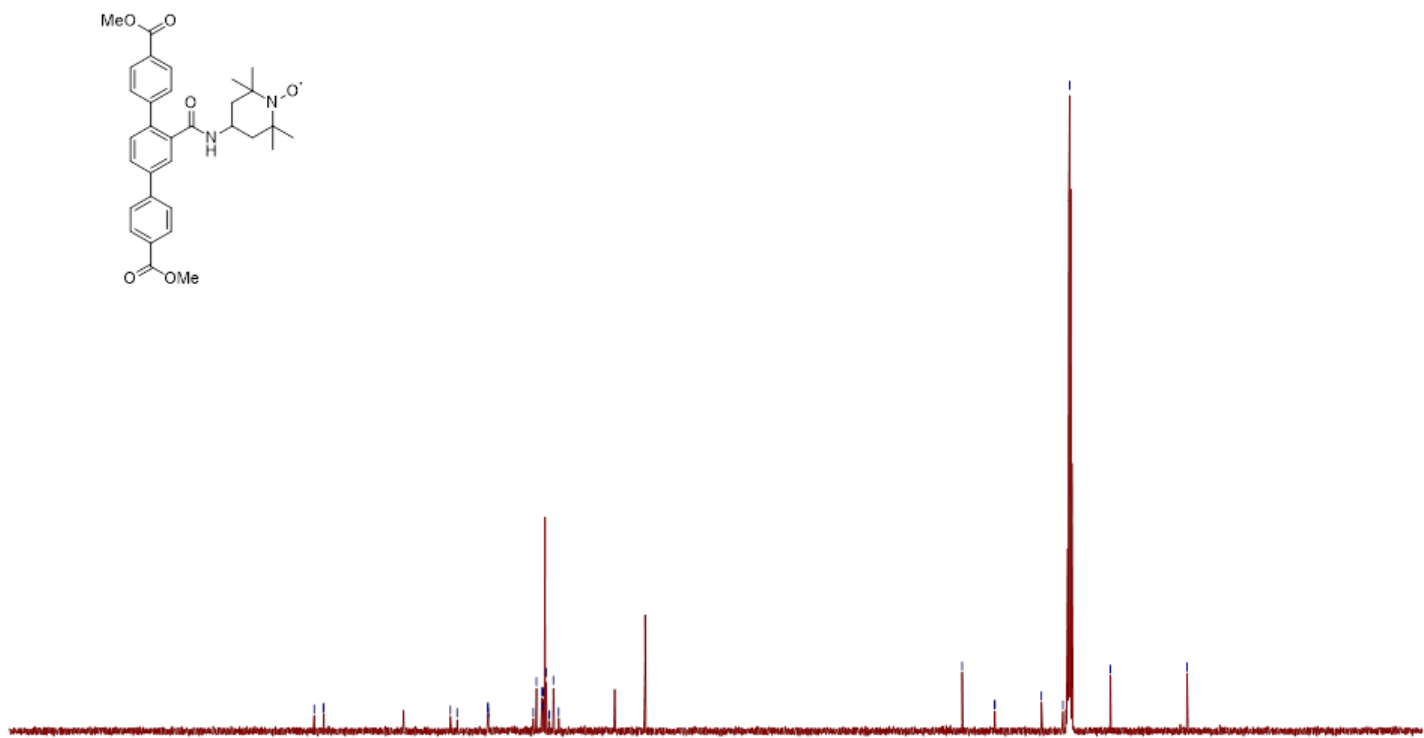

$\begin{array}{lllllllllllllllllllllllll}210 & 200 & 190 & 180 & 170 & 160 & 150 & 140 & 130 & 120 & 110 & 100 & 90 & 80 & 70 & 60 & 50 & 40 & 30 & 20 & 10 & 0 & -10 & -20\end{array}$ 
TPDC-TEMPO $\left(500 \mathrm{MHz}\right.$ for ${ }^{1} \mathrm{H}$ and $125 \mathrm{MHz}$ for ${ }^{13} \mathrm{C}\left\{{ }^{1} \mathrm{H}\right\}$ in DMSO- $\left.d_{6}\right)$
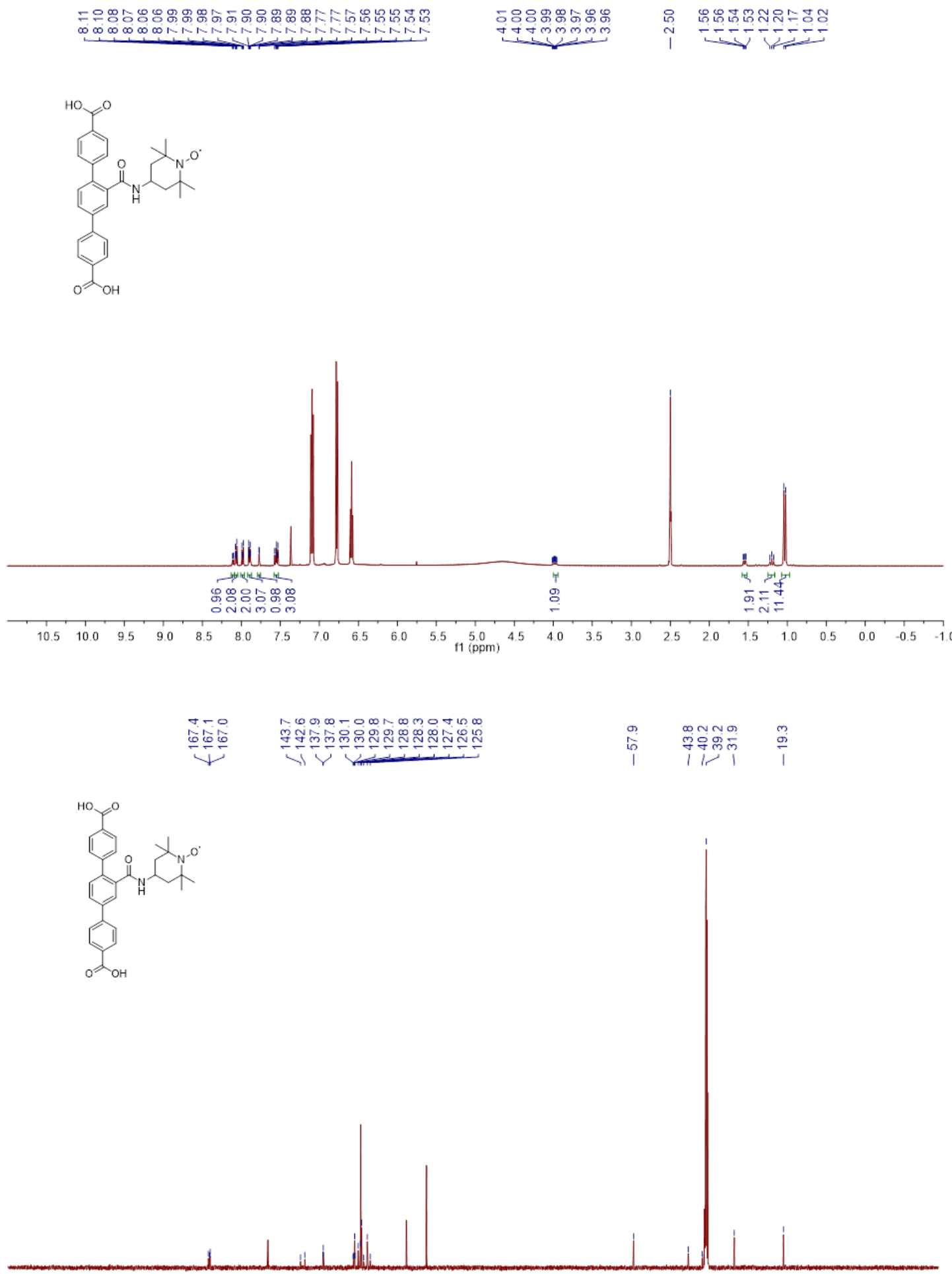

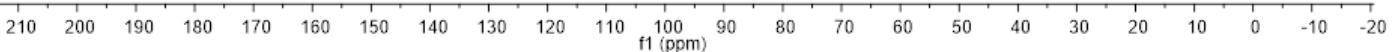


MOF-TEMPO after acid digestion with $\mathrm{HF}\left(500 \mathrm{MHz}\right.$ for ${ }^{1} \mathrm{H}$ and $125 \mathrm{MHz}$ for ${ }^{13} \mathrm{C}\left\{{ }^{1} \mathrm{H}\right\}$ in DMSO- $\left.d_{6}\right)$
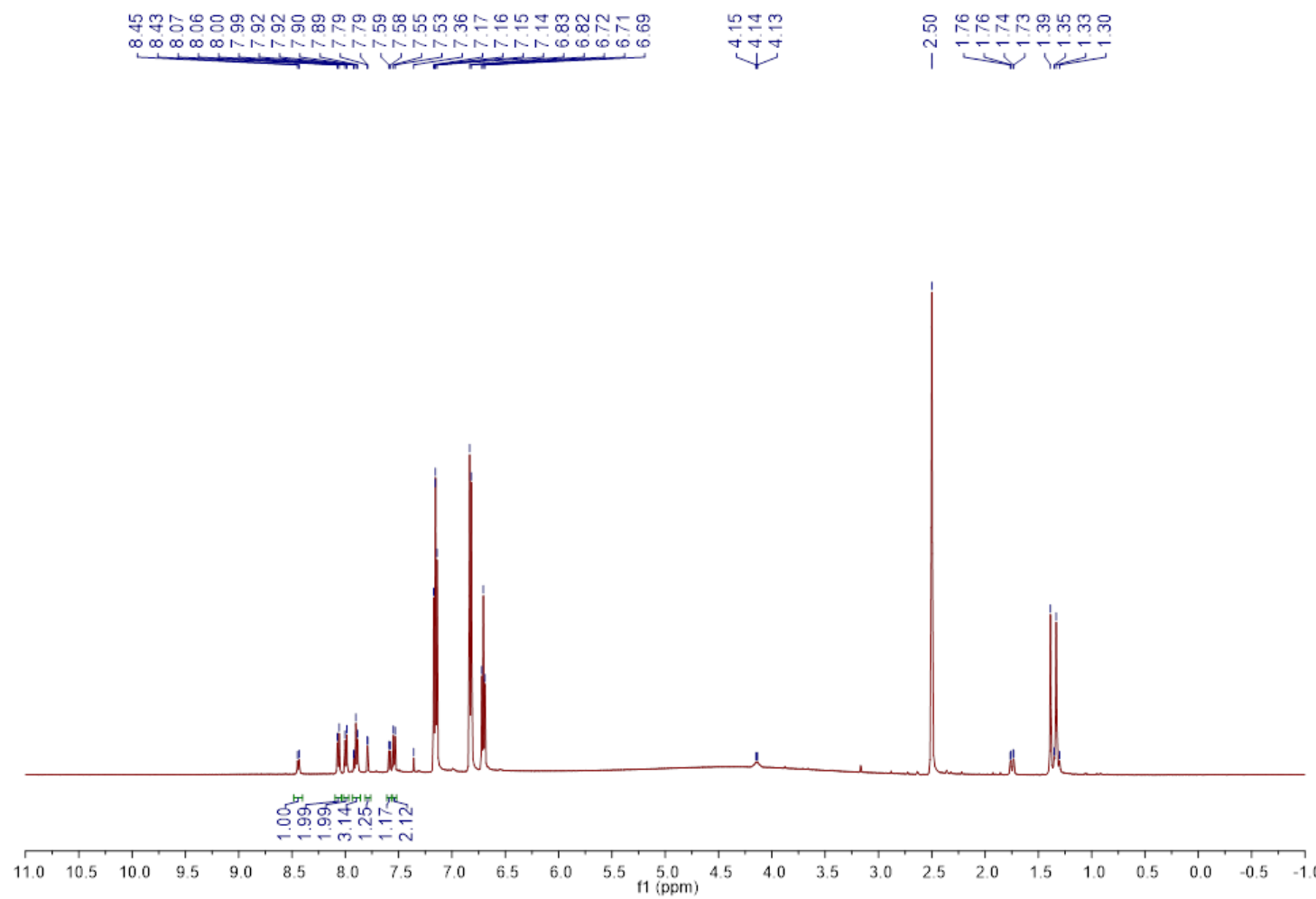
In-situ NMR of the reaction mixture under heating at $80^{\circ} \mathrm{C}$ for $\mathbf{O} \mathbf{~ h} .\left(500 \mathrm{MHz}\right.$ in $\left.\mathrm{CD}_{3} \mathrm{CN}-d_{3}\right)$

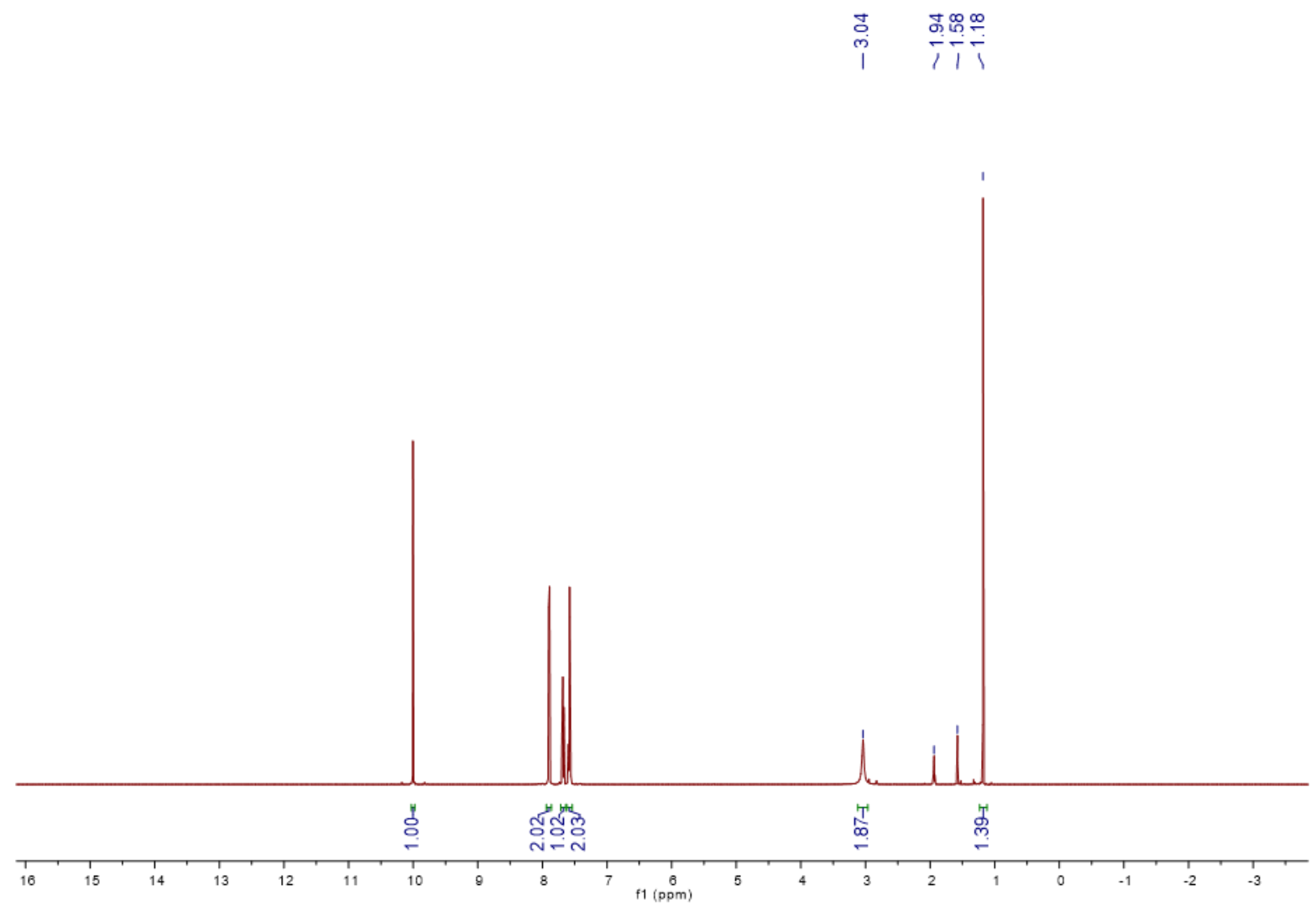


In-situ NMR of the reaction mixture under heating at $80^{\circ} \mathrm{C}$ for $1 \mathrm{~h} .\left(500 \mathrm{MHz}\right.$ in $\left.\mathrm{CD}_{3} \mathrm{CN}-d_{3}\right)$

|

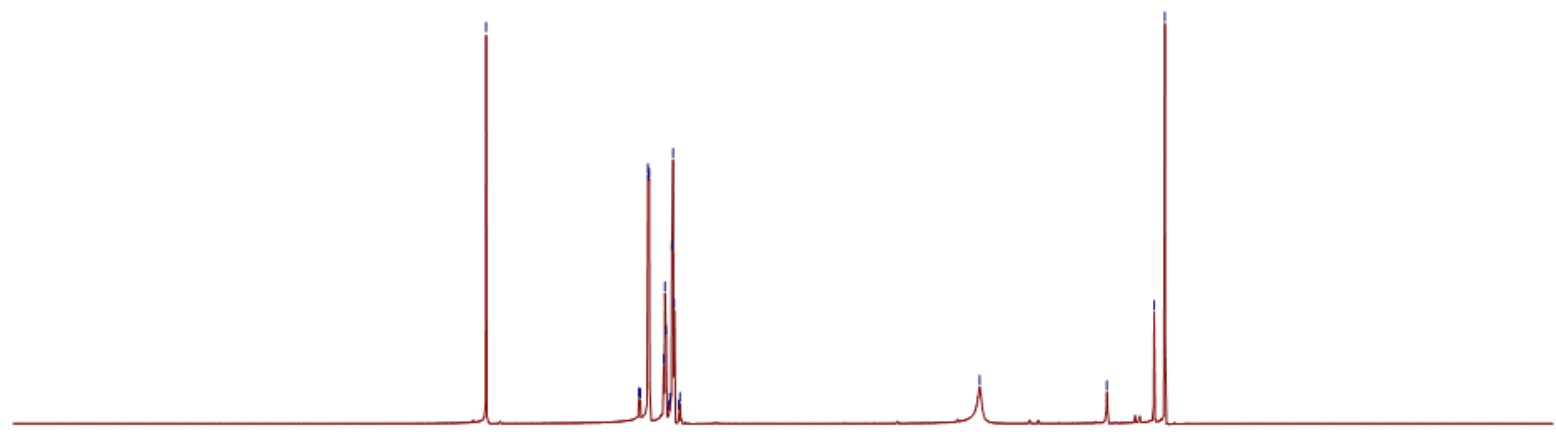

\begin{tabular}{lllllllllllllllllllllll}
\hline 16 & 15 & 14 & 13 & 12 & 11 & 10 & 9 & 8 & 7 & $\begin{array}{l}6 \\
\mathrm{f} 1(\mathrm{ppm})\end{array}$ & 5 & 4 & 3 & 2 & 1 & 0 & -1 & -2 & -3
\end{tabular} 
In-situ NMR of the reaction mixture under heating at $80^{\circ} \mathbf{C}$ for $2 \mathbf{h}$. $\left(500 \mathrm{MHz}\right.$ in $\left.\mathrm{CD}_{3} \mathrm{CN}-d_{3}\right)$
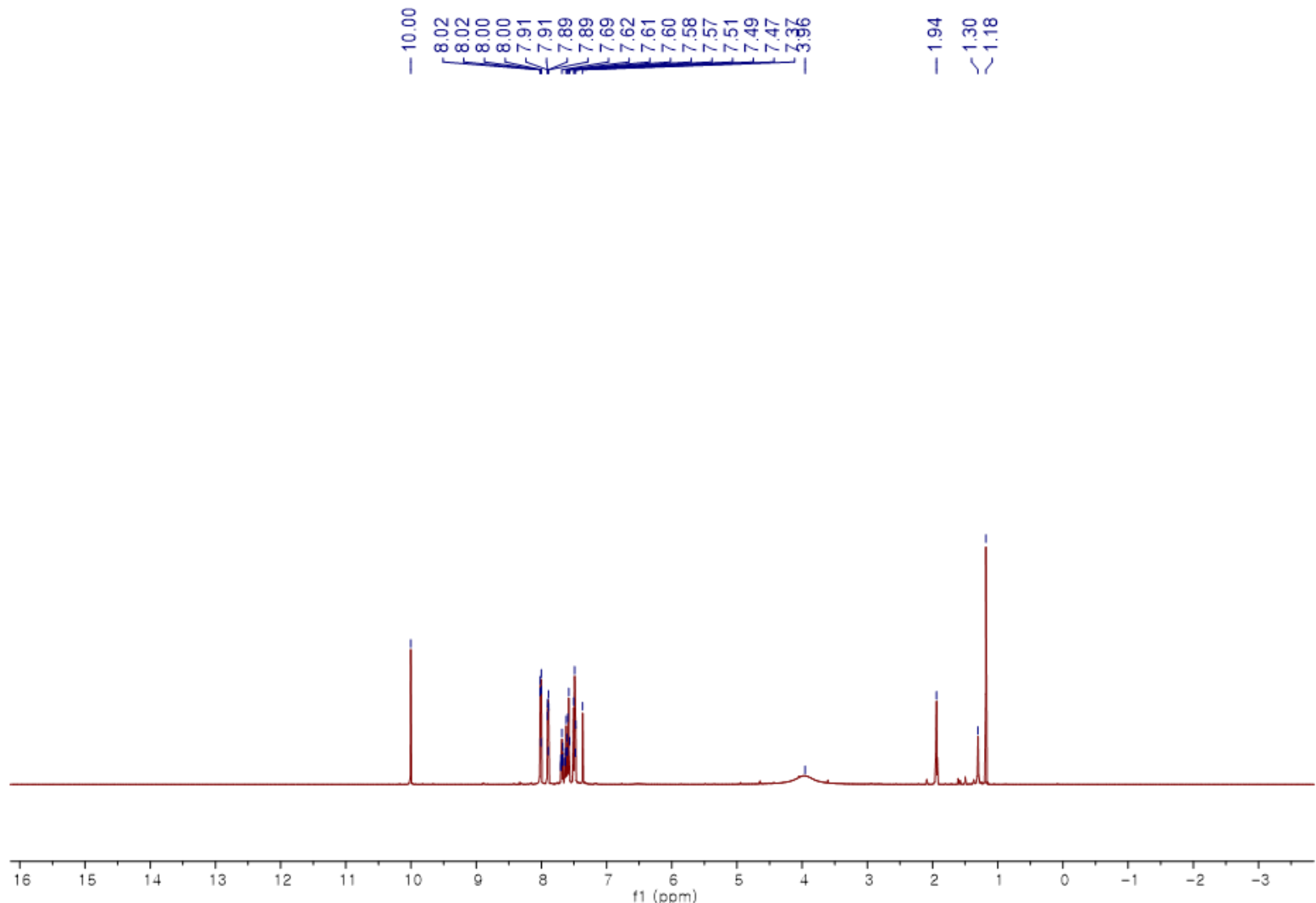
In-situ NMR of the reaction mixture under heating at $80^{\circ} \mathrm{C}$ for $3 \mathbf{~ h}$. $\left(500 \mathrm{MHz}\right.$ in $\left.\mathrm{CD}_{3} \mathrm{CN}-d_{3}\right)$
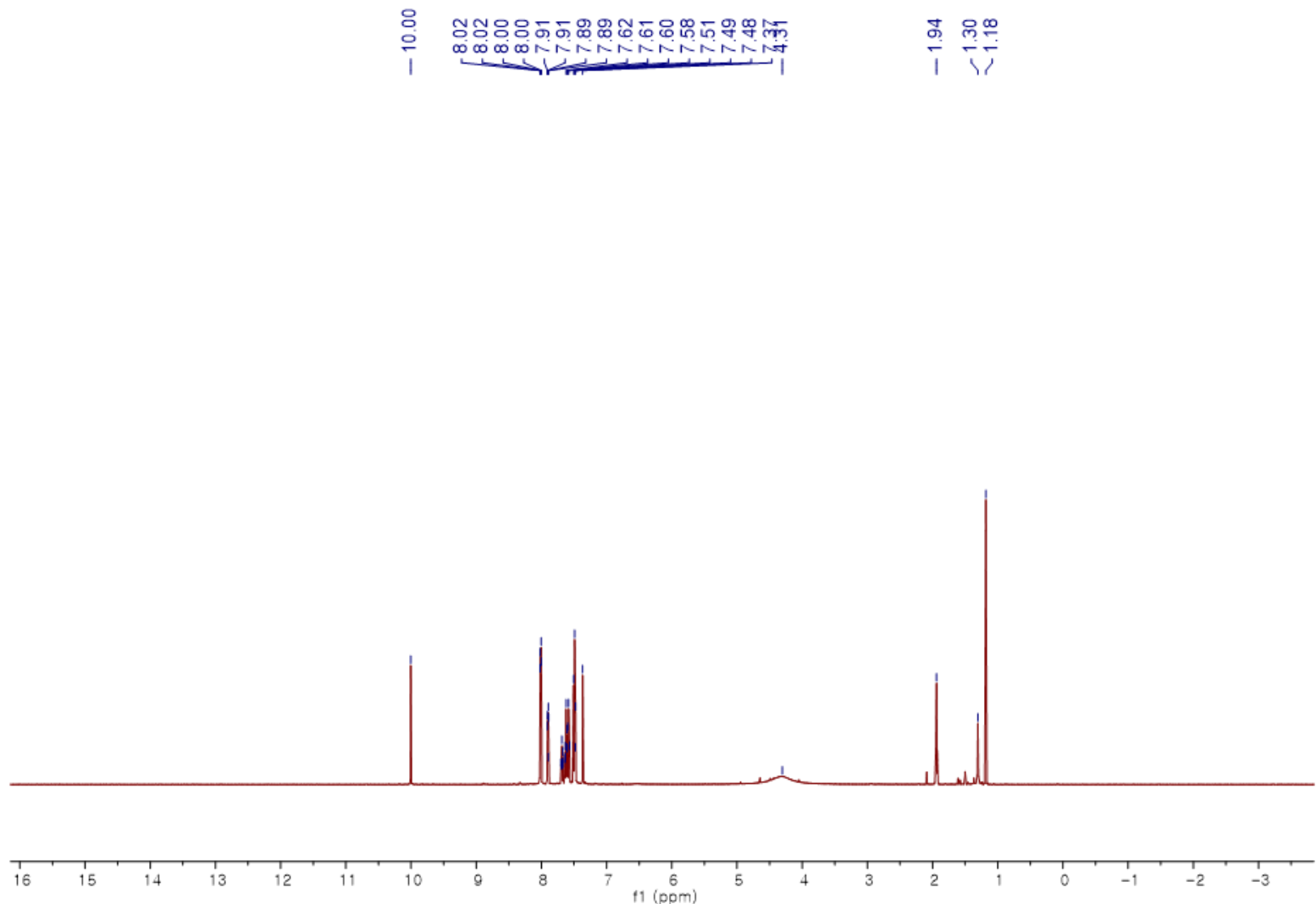
In-situ NMR of the reaction mixture under heating at $80^{\circ} \mathrm{C}$ for $4 \mathbf{h}$. $\left(500 \mathrm{MHz}\right.$ in $\left.\mathrm{CD}_{3} \mathrm{CN}-d_{3}\right)$
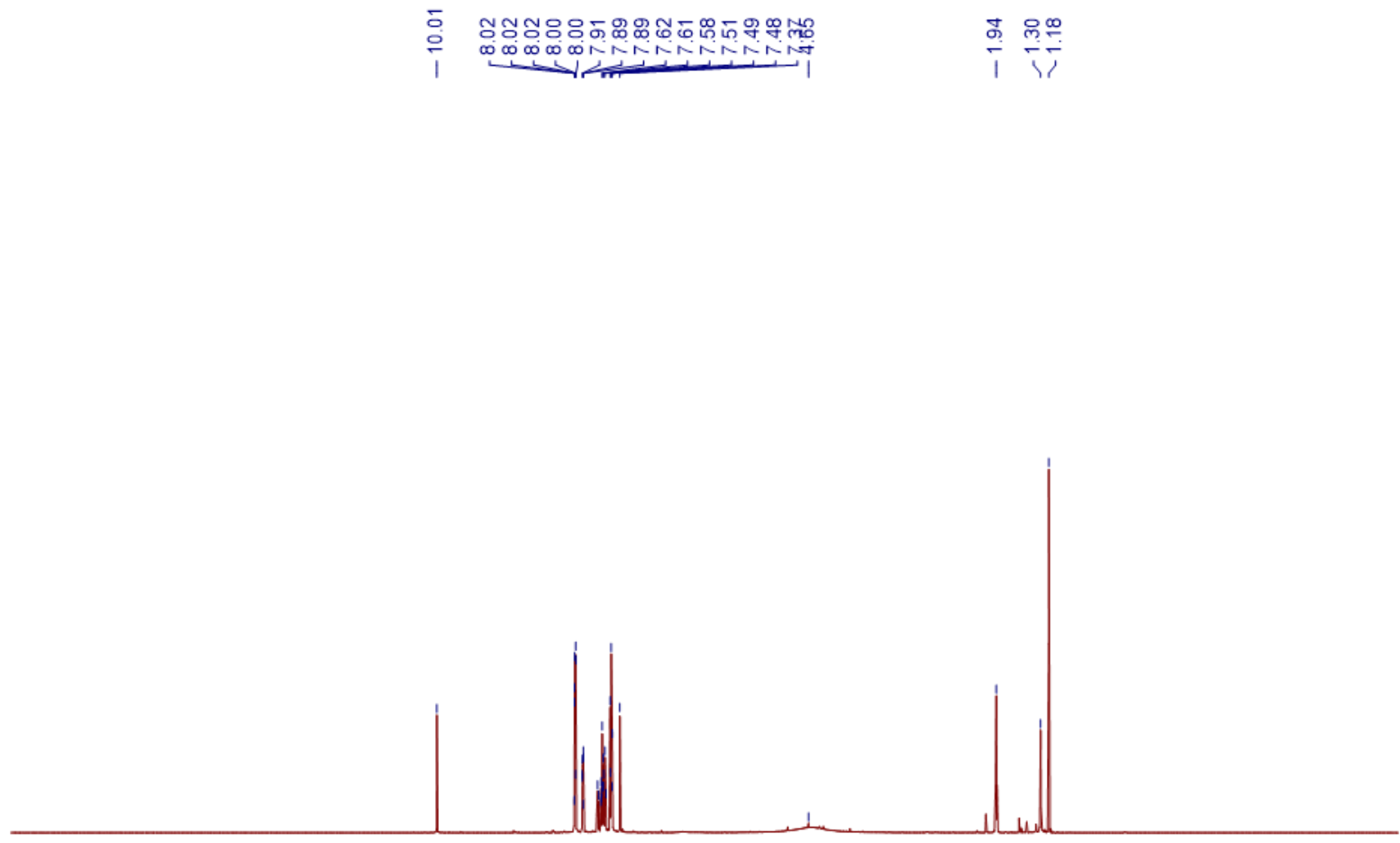

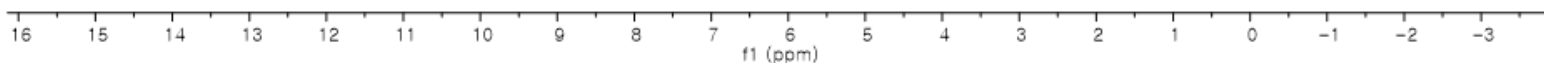


In-situ NMR of the reaction mixture under heating at $80^{\circ} \mathbf{C}$ for $8 \mathbf{~ h} .\left(500 \mathrm{MHz}\right.$ in $\left.\mathrm{CD}_{3} \mathrm{CN}-d_{3}\right)$
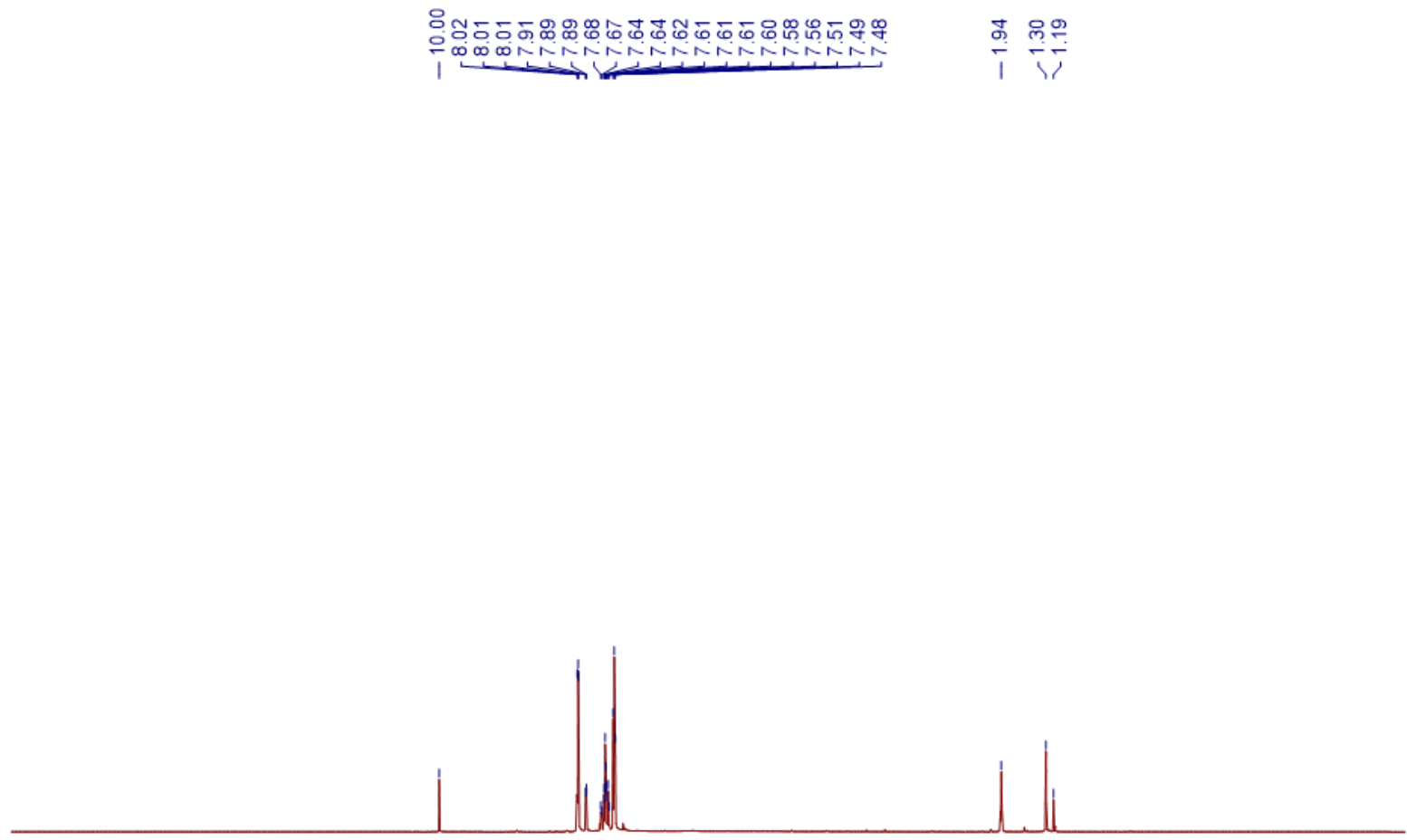

\begin{tabular}{lllllllllllllllllllllllll}
\hline 16 & 15 & 14 & 13 & 12 & 11 & 10 & 9 & 8 & 7 & $\begin{array}{c}1 \\
\mathrm{f} 1(\mathrm{ppm})\end{array}$ & 5 & 4 & 3 & 2 & 1 & 0 & -1 & -2 & -3 & 1
\end{tabular} 
In-situ NMR of the reaction mixture under heating at $80^{\circ} \mathrm{C}$ for $10 \mathrm{~h} .\left(500 \mathrm{MHz}\right.$ in $\left.\mathrm{CD}_{3} \mathrm{CN}-d_{3}\right)$

응
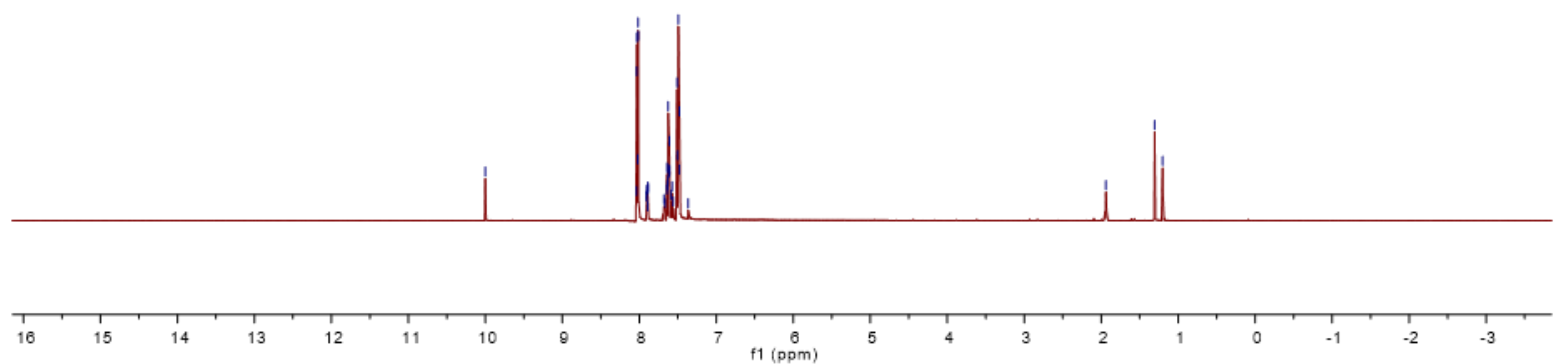
tert-Butyl nitrite $\left(500 \mathrm{MHz}{ }^{1} \mathrm{H} \mathrm{NMR}\right.$ in $\left.\mathrm{CD}_{3} \mathrm{CN}\right)$

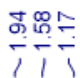

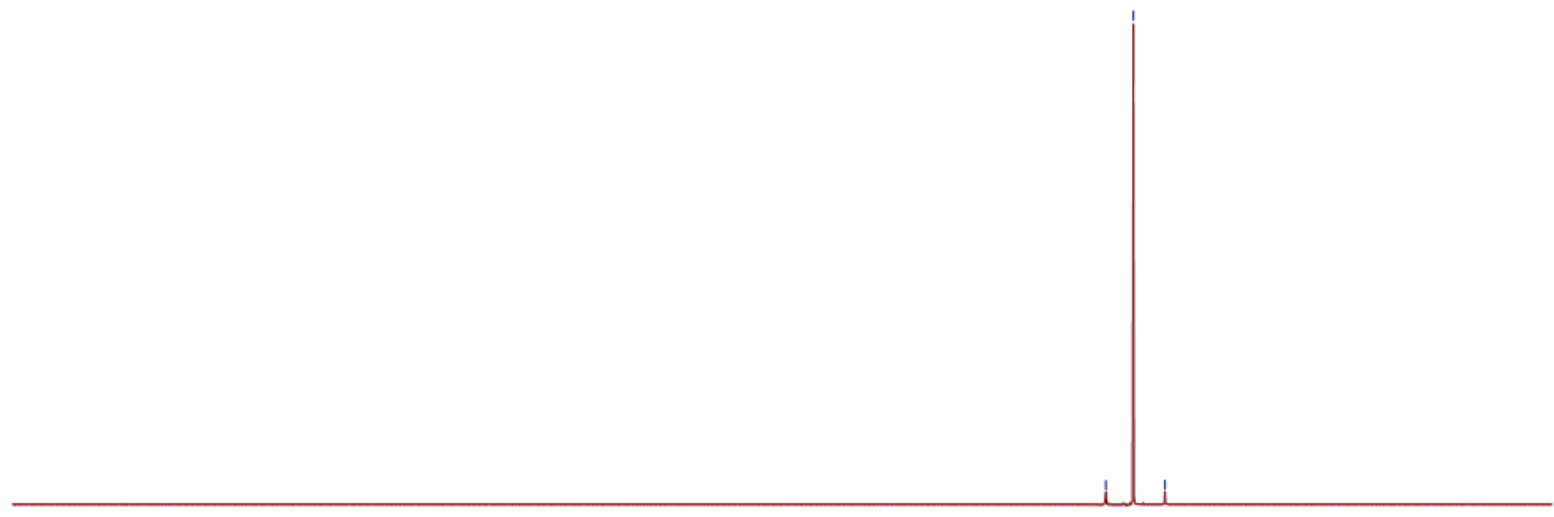

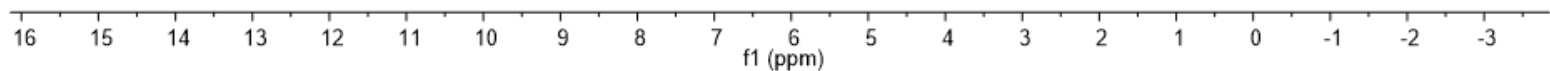


tert-Butyl alcohol $\left(500 \mathrm{MHz}{ }^{1} \mathrm{H}\right.$ NMR in $\left.\mathrm{CD}_{3} \mathrm{CN}\right)$

$$
\stackrel{1}{\stackrel{1}{\circ}}
$$

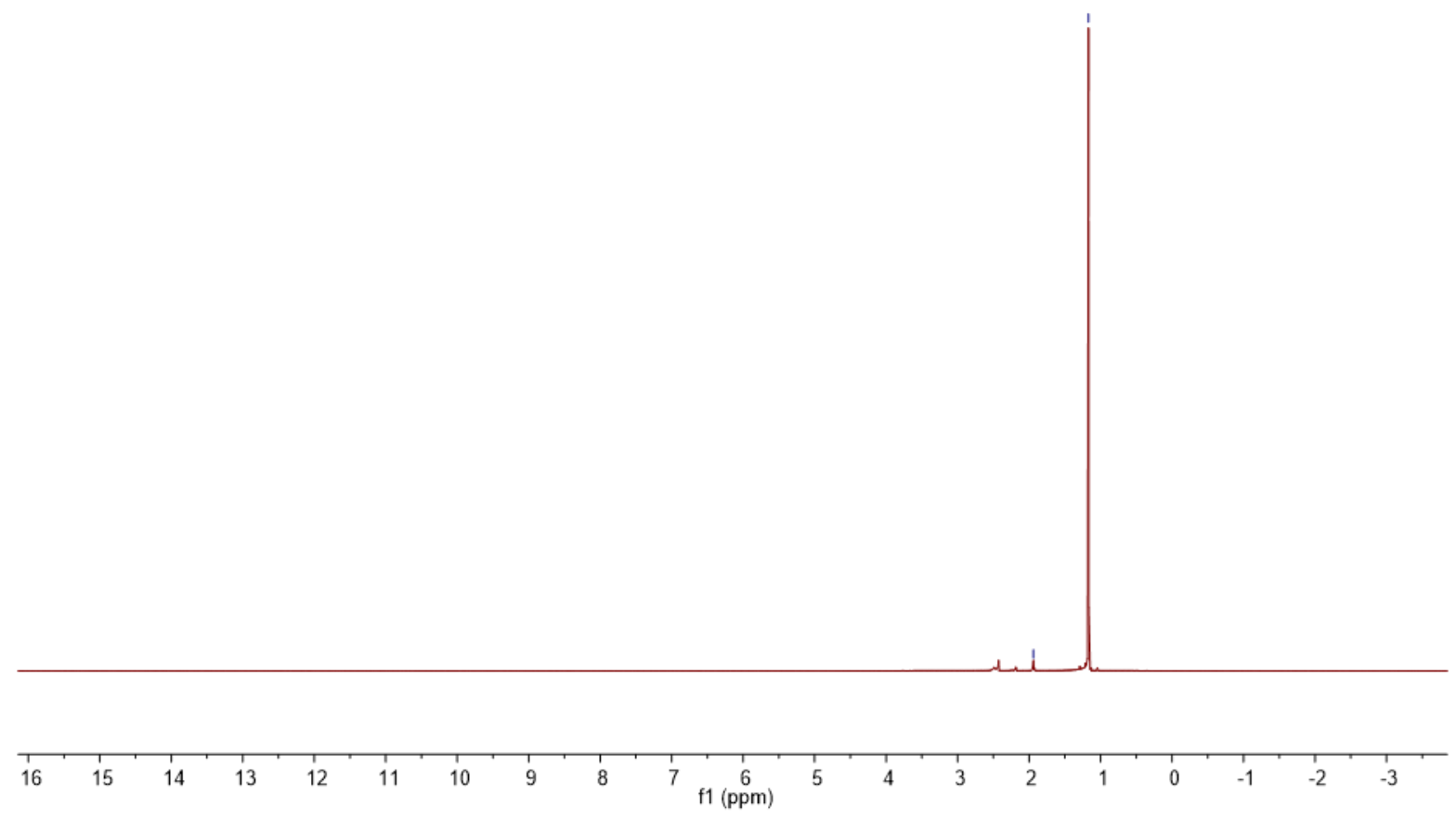


In-situ NMR of tert-Butyl nitrite under heating at $80^{\circ} \mathrm{C}$ for $0.5 \mathrm{~h} .\left(500 \mathrm{MHz}\right.$ in $\left.\mathrm{CD}_{3} \mathrm{CN}-d_{3}\right)$

方

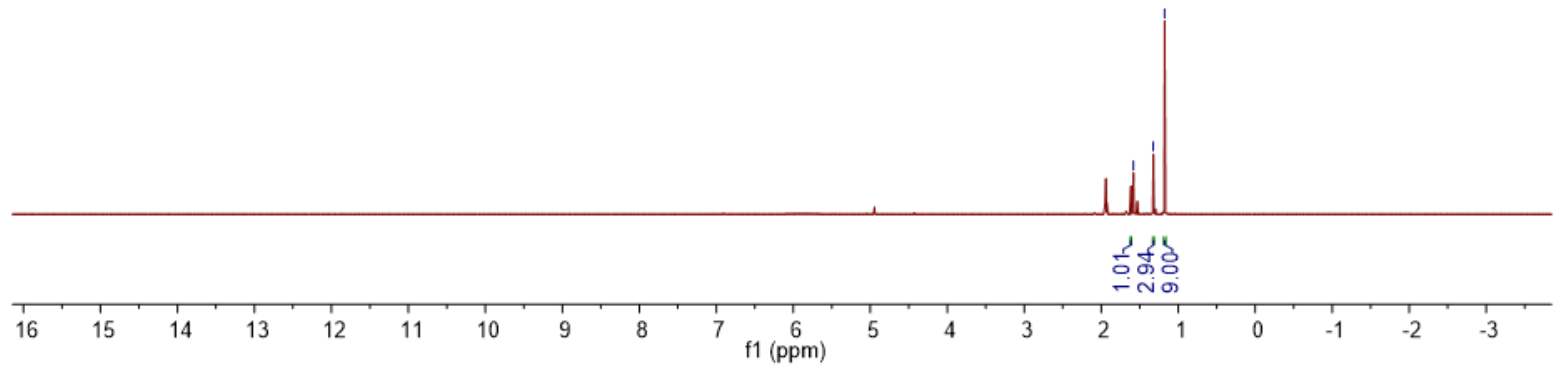


In-situ NMR of tert-Butyl nitrite under heating at $80{ }^{\circ} \mathrm{C}$ for $10 \mathrm{~h} .\left(500 \mathrm{MHz}\right.$ in $\left.\mathrm{CD}_{3} \mathrm{CN}-d_{3}\right)$

$$
\text { ธ్ ตำ }
$$

ज5

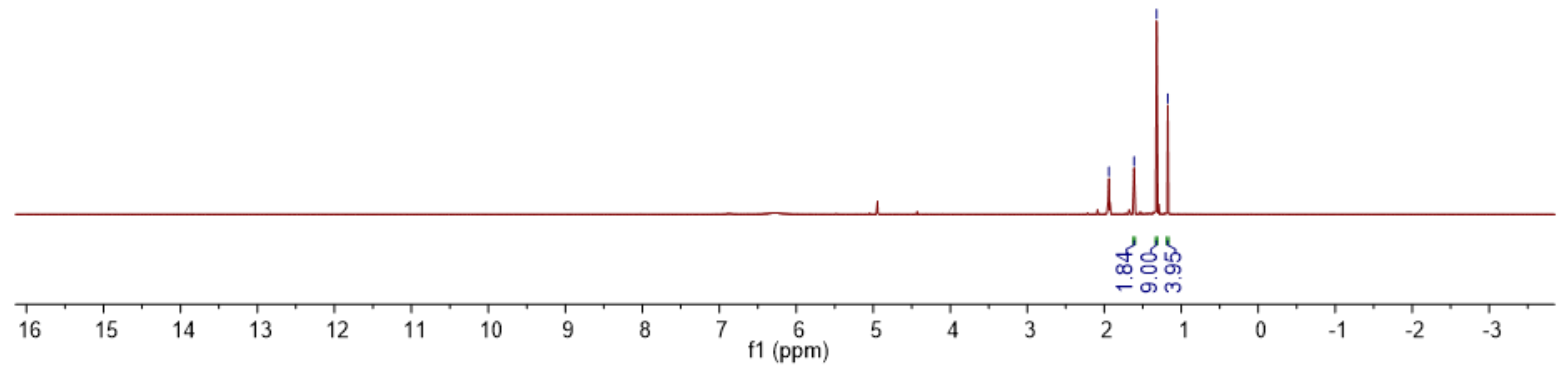


1,3-bis-(2,6-diisopropylphenyl)imidazolylidene ( $\mathrm{NHC}$, IPr, 4a) $\left(500 \mathrm{MHz}\right.$ in $\left.\mathrm{C}_{6} \mathrm{D}_{6}\right)$

\begin{tabular}{|c|c|}
\hline 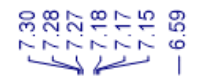 & 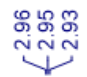 \\
\hline
\end{tabular}

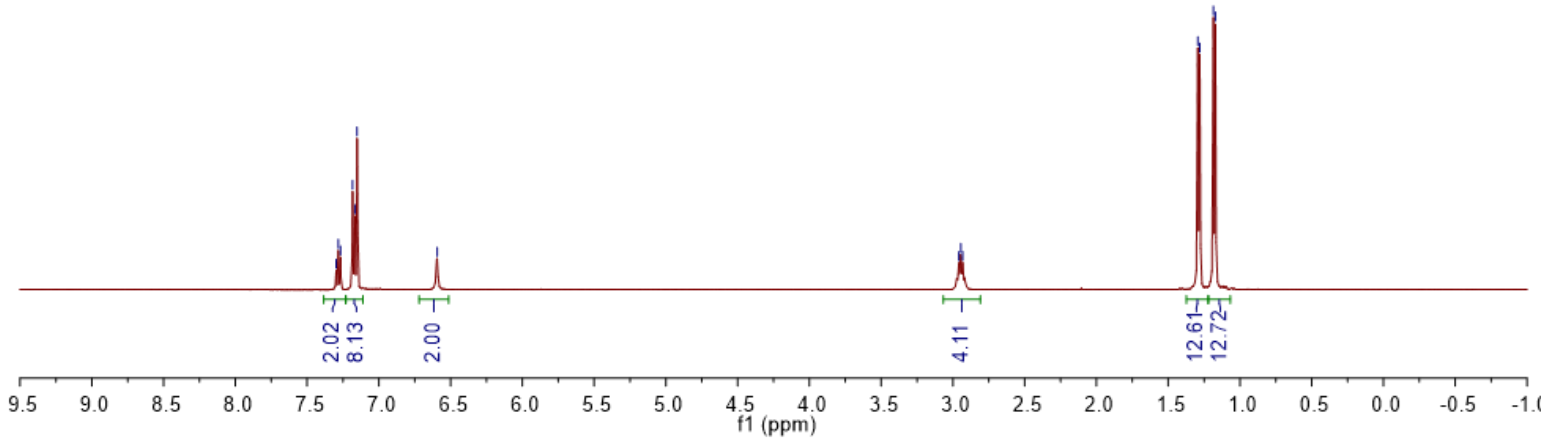


In-situ NMR of tert-Butyl nitrite under $\mathrm{O}_{2}$ atmosphere at $25^{\circ} \mathrm{C}+\mathrm{NHC}\left(500 \mathrm{MHz}\right.$ in $\left.\mathrm{C}_{6} \mathrm{D}_{6}\right)$

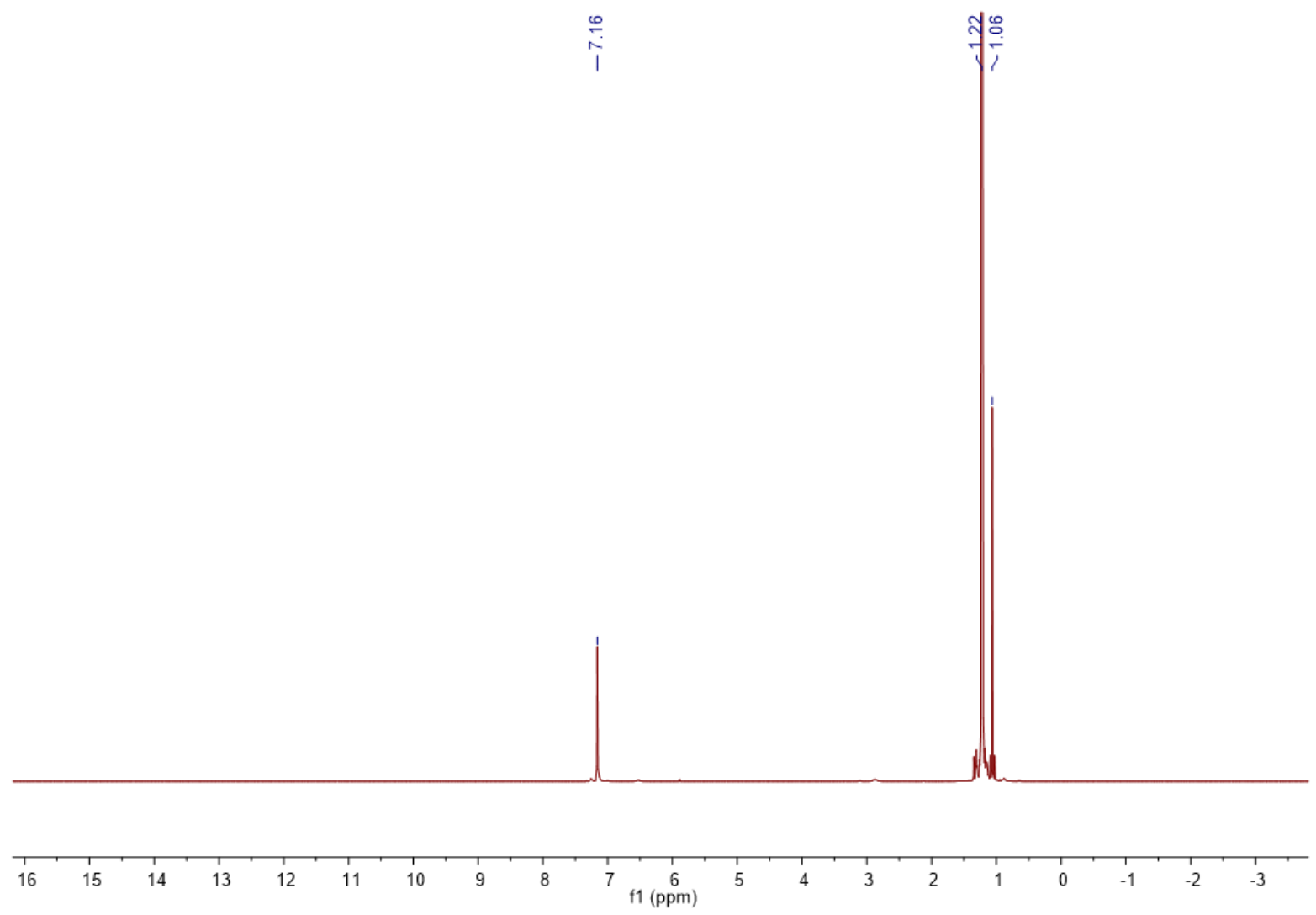


In-situ NMR of tert-Butyl nitrite under $\mathrm{O}_{2}$ atmosphere at $80^{\circ} \mathrm{C}+\mathrm{NHC}\left(500 \mathrm{MHz}\right.$ in $\left.\mathrm{C}_{6} \mathrm{D}_{6}\right)$

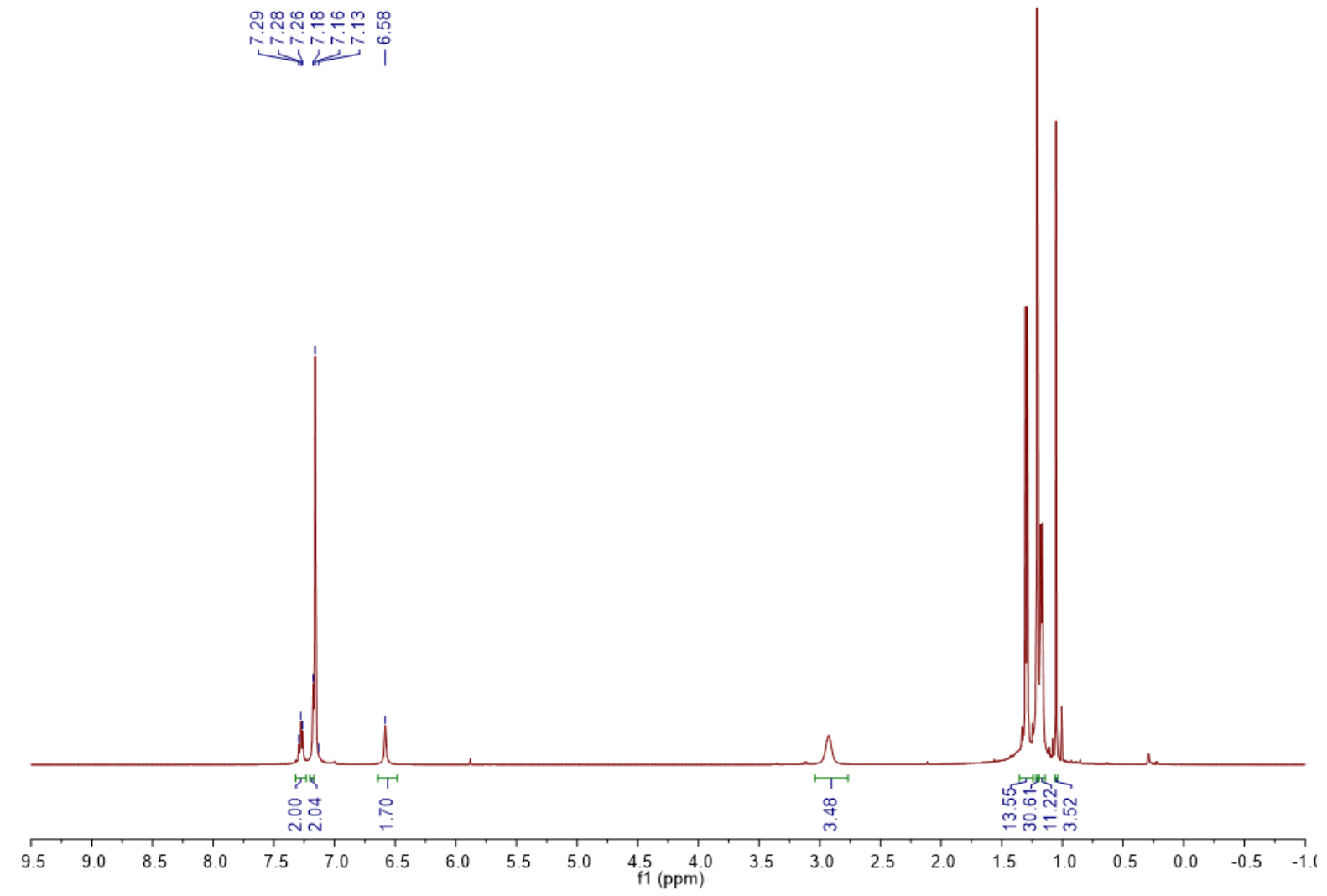


In-situ NMR of antioxidant test with benzaldhyde alone $\left(500 \mathrm{MHz}\right.$ in $\left.\mathrm{CD}_{3} \mathrm{CN}-d_{3}\right)$

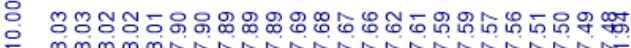

$$
\begin{aligned}
& 1 \underbrace{\infty}
\end{aligned}
$$

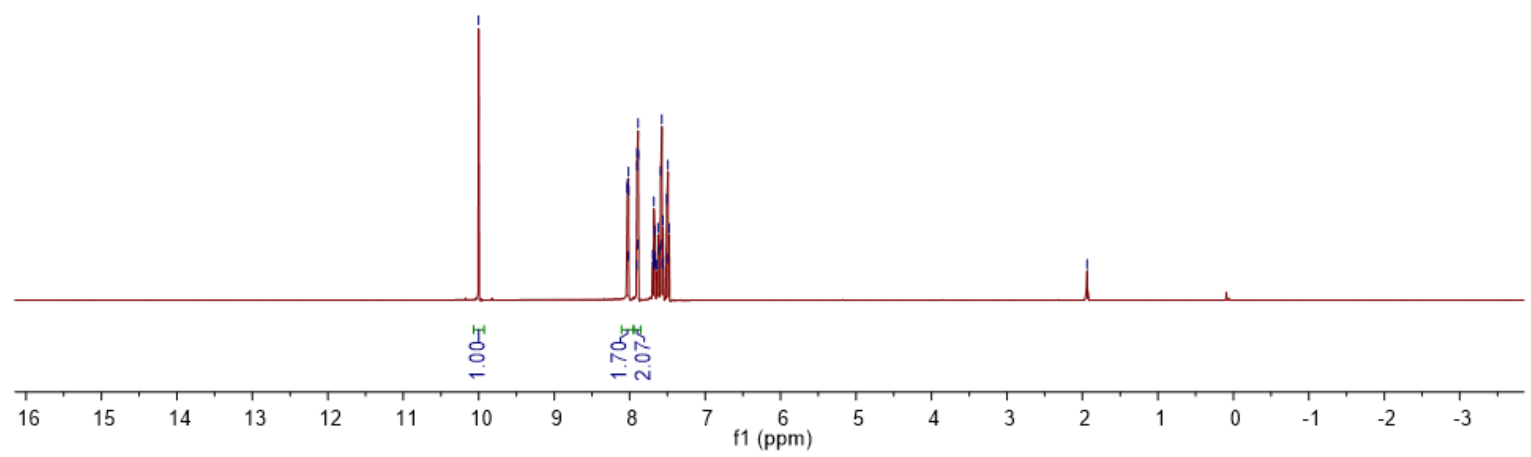


In-situ NMR of antioxidant test with benzaldhyde + MOF-TEMPO together $\left(500 \mathrm{MHz}\right.$ in $\left.\mathrm{CD}_{3} \mathrm{CN}-d_{3}\right)$
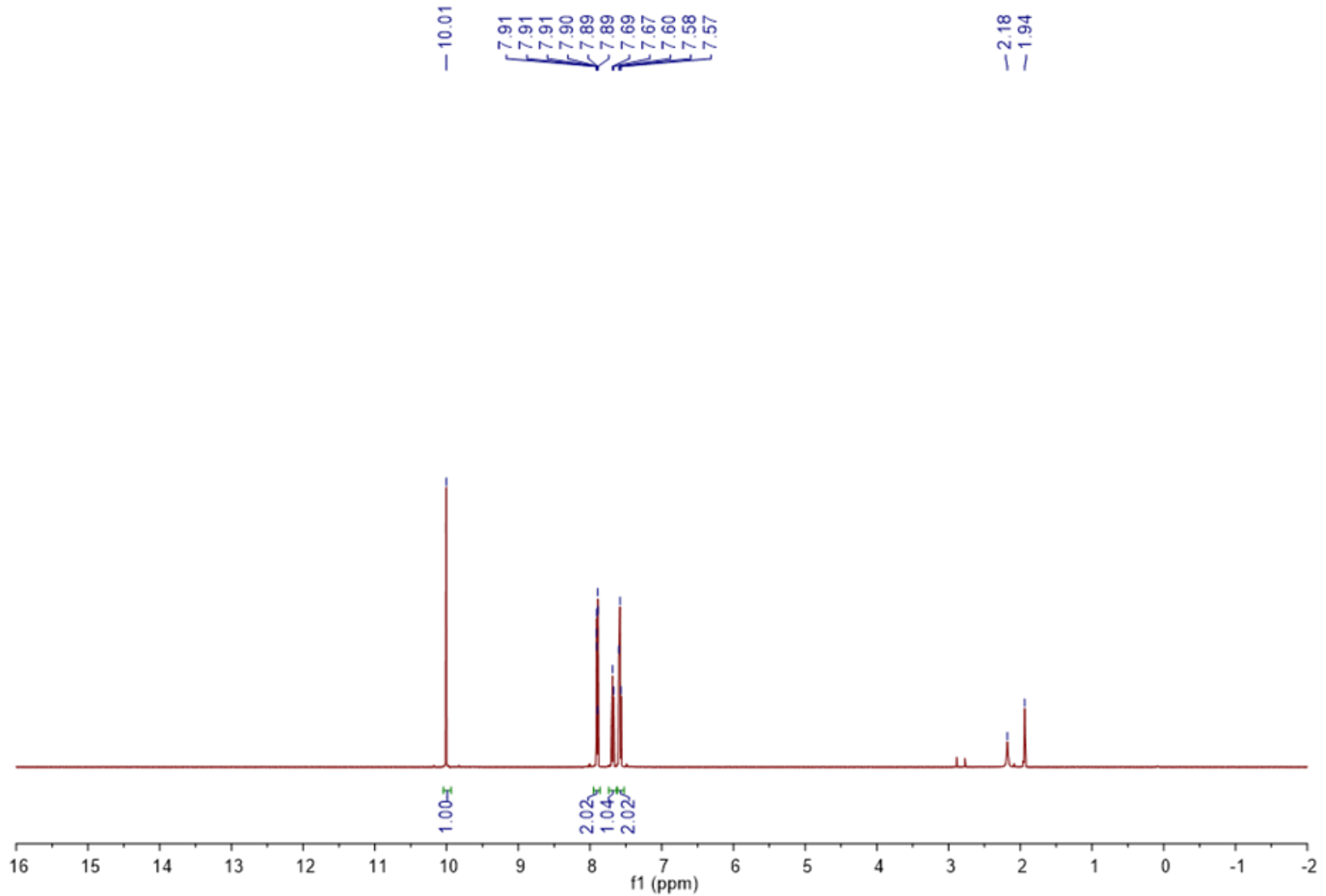
Benzoic acid (3a, $500 \mathrm{MHz}$ for ${ }^{1} \mathrm{H}$ and $125 \mathrm{MHz}$ for ${ }^{13} \mathrm{C}\left\{{ }^{1} \mathrm{H}\right\}$ in $\mathrm{CDCl}_{3}$ )

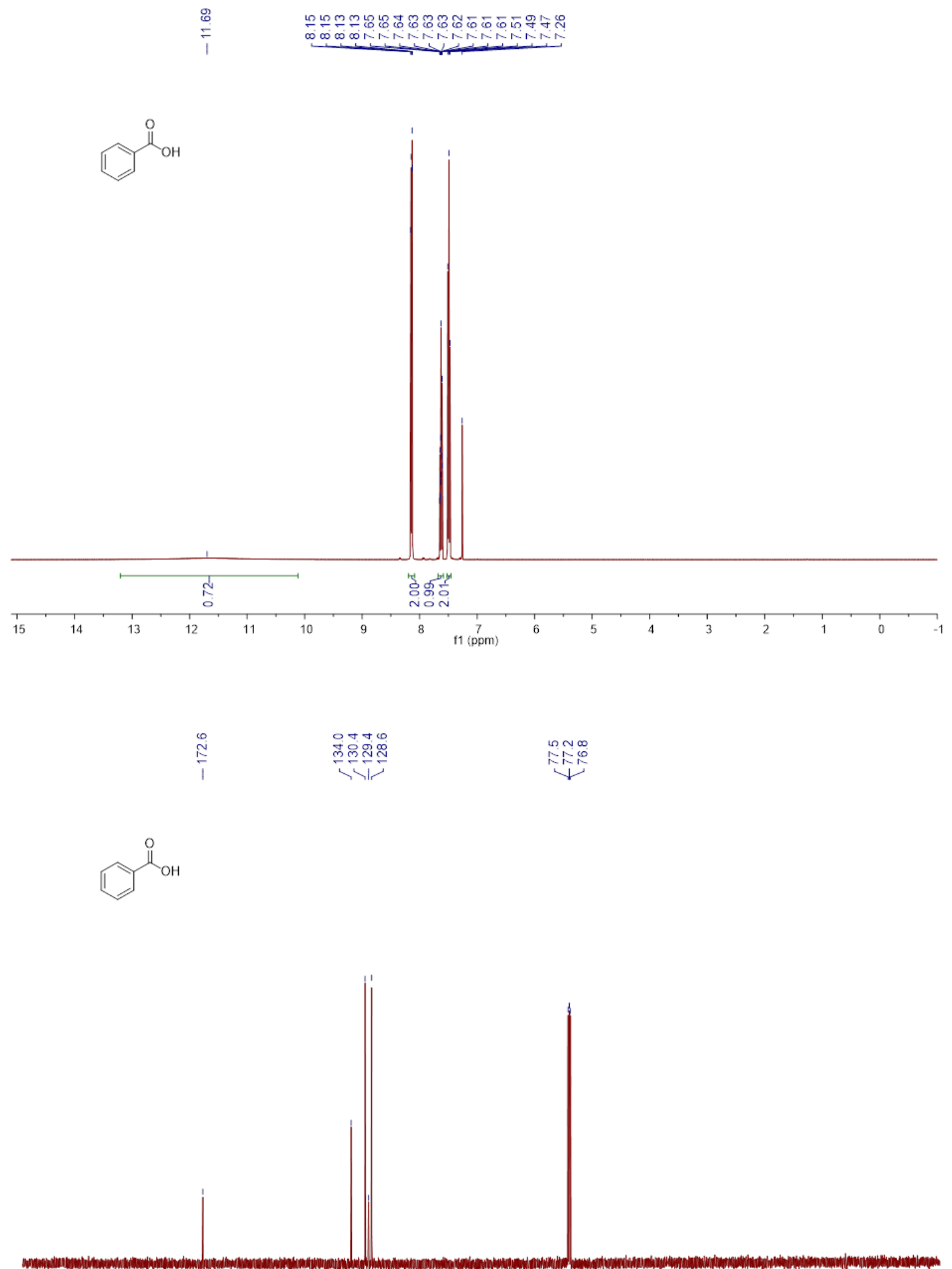

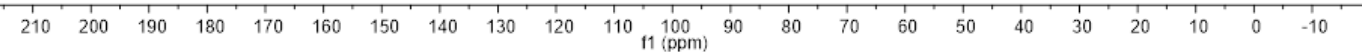


4-Methylbenzoic acid (3b, $500 \mathrm{MHz}$ for ${ }^{1} \mathrm{H}$ and $125 \mathrm{MHz}$ for ${ }^{13} \mathrm{C}\left\{{ }^{1} \mathrm{H}\right\}$ in DMSO- $d_{6}$ )

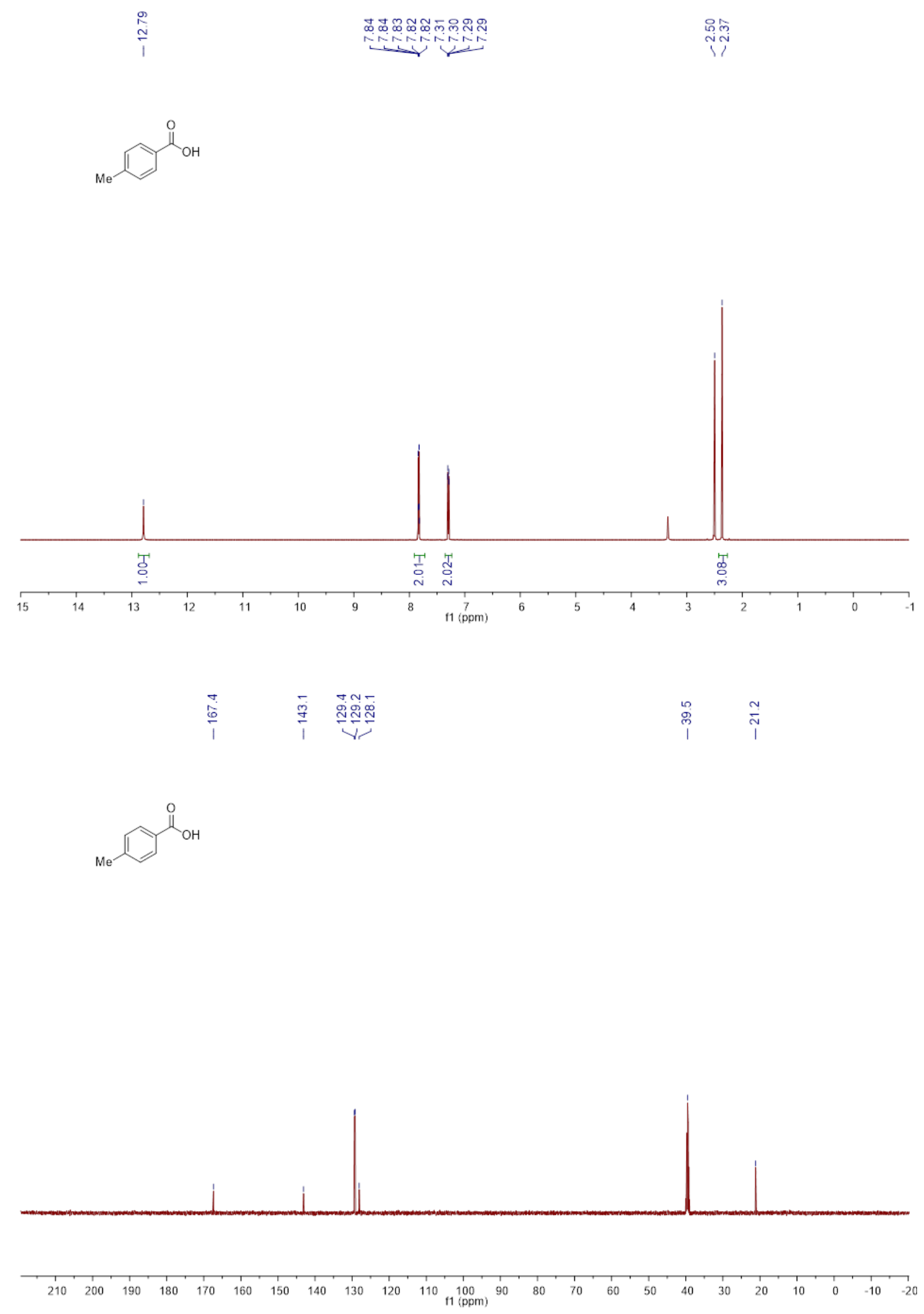


3-Methylbenzoic acid (3C, $500 \mathrm{MHz}$ for ${ }^{1} \mathrm{H}$ and $125 \mathrm{MHz}$ for ${ }^{13} \mathrm{C}\left\{{ }^{1} \mathrm{H}\right\}$ in DMSO-d $)$

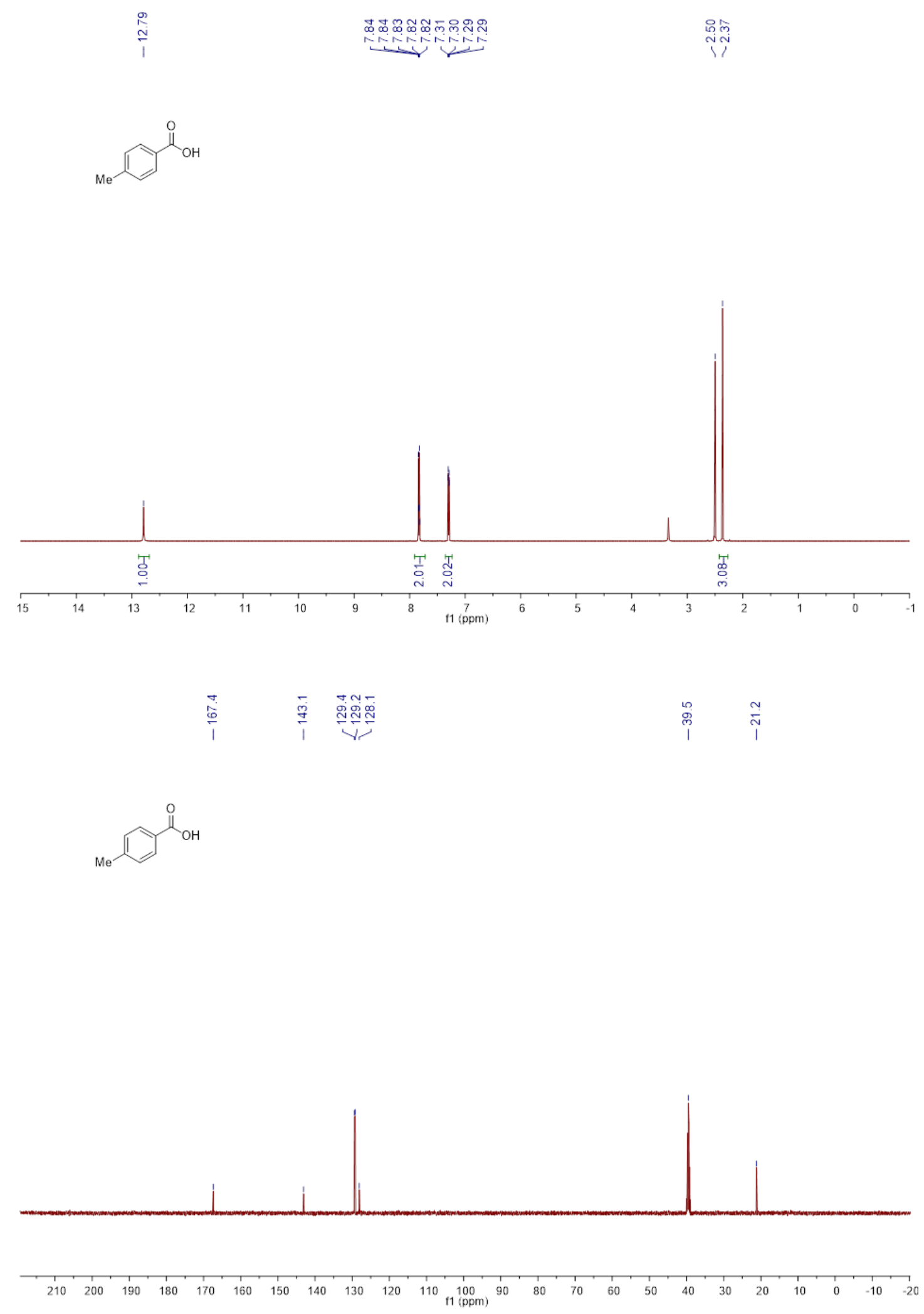


2-Methylbenzoic acid (3d, $500 \mathrm{MHz}$ for ${ }^{1} \mathrm{H}$ and $125 \mathrm{MHz}$ for ${ }^{13} \mathrm{C}\left\{{ }^{1} \mathrm{H}\right\}$ in DMSO- $d_{6}$ )
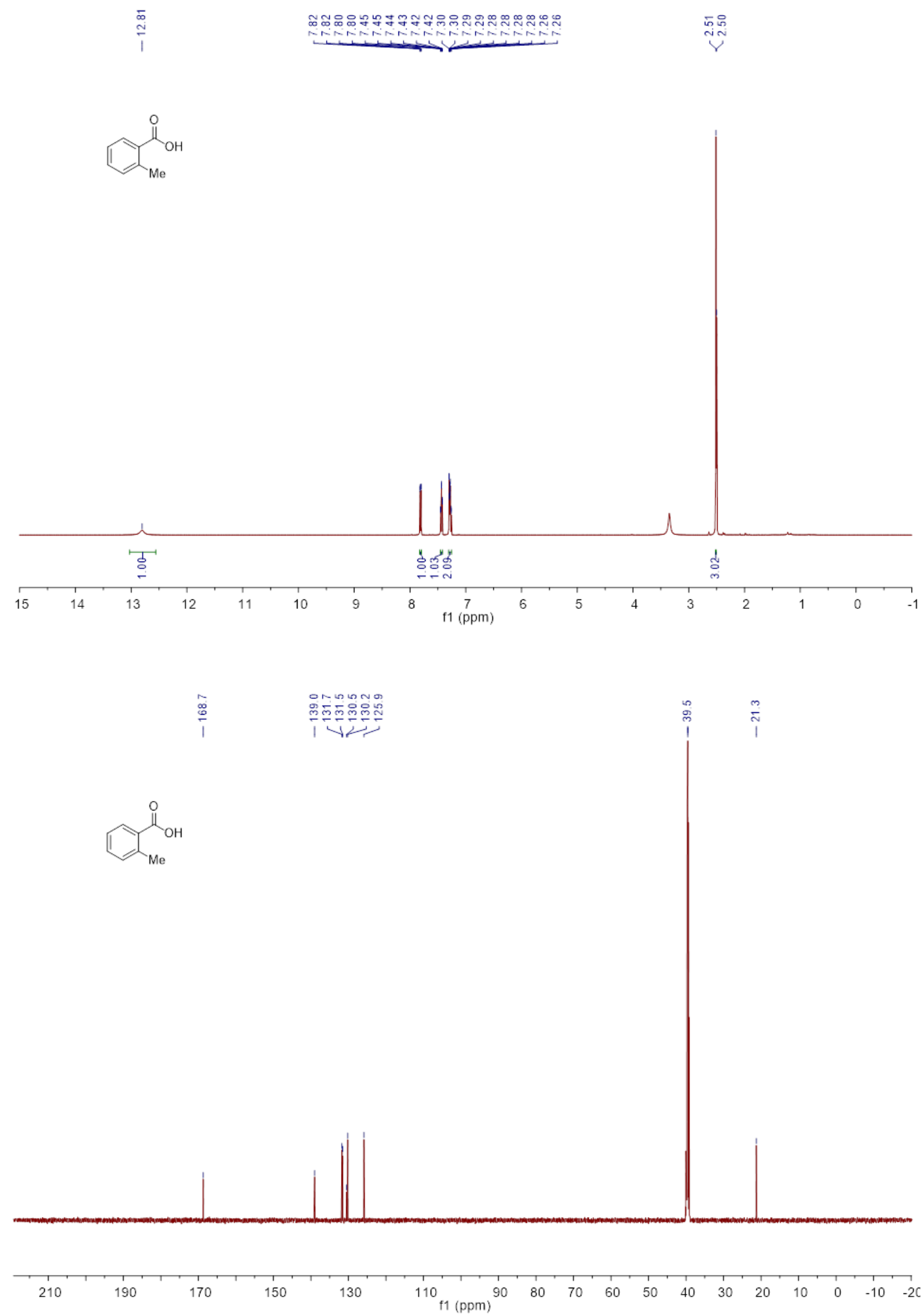
4-lodobenzoic acid (3e, $500 \mathrm{MHz}$ for ${ }^{1} \mathrm{H}$ and $125 \mathrm{MHz}$ for ${ }^{13} \mathrm{C}\left\{{ }^{1} \mathrm{H}\right\}$ in DMSO- $\left.d_{6}\right)$
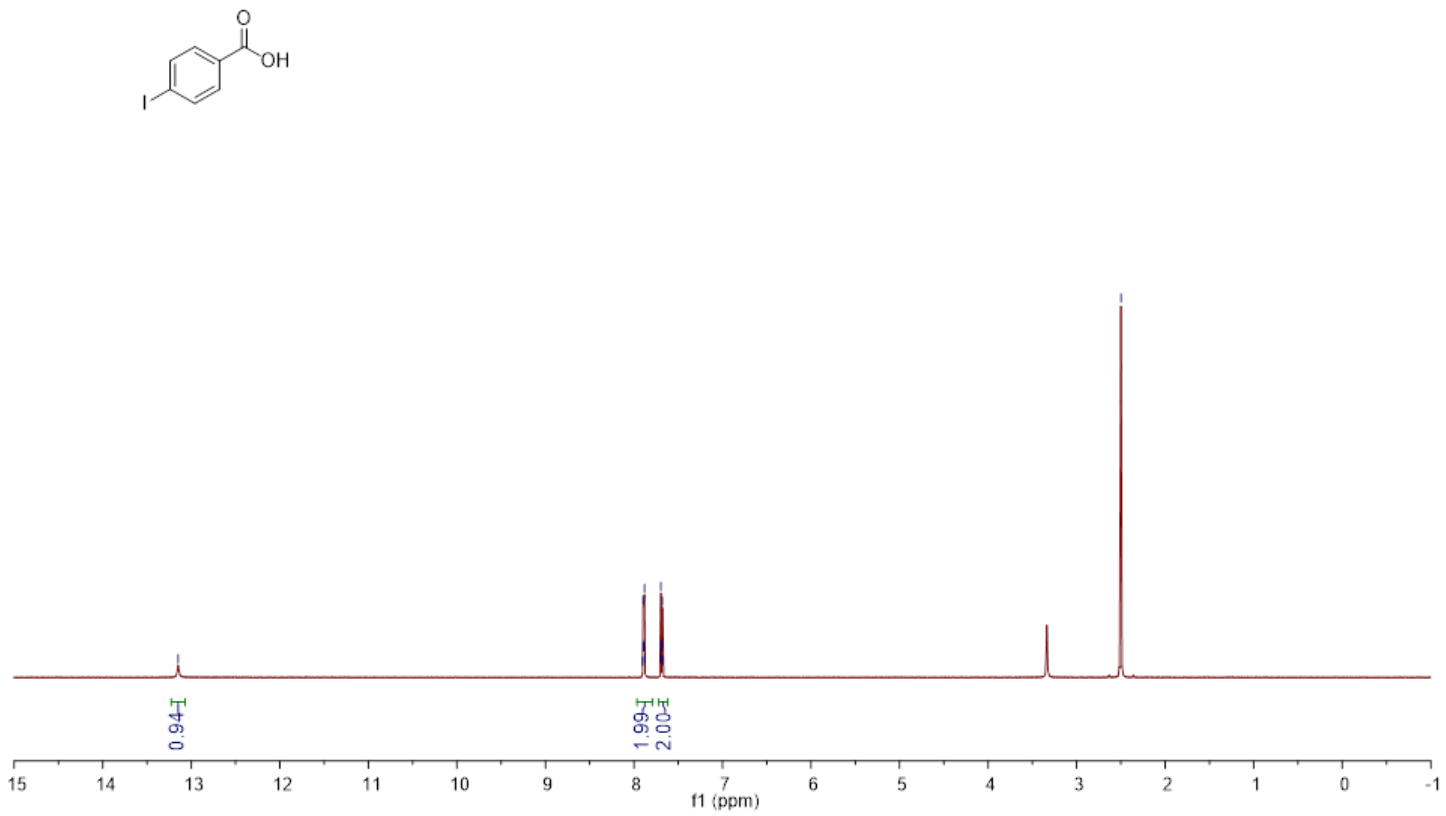

$\frac{9}{1}$ i
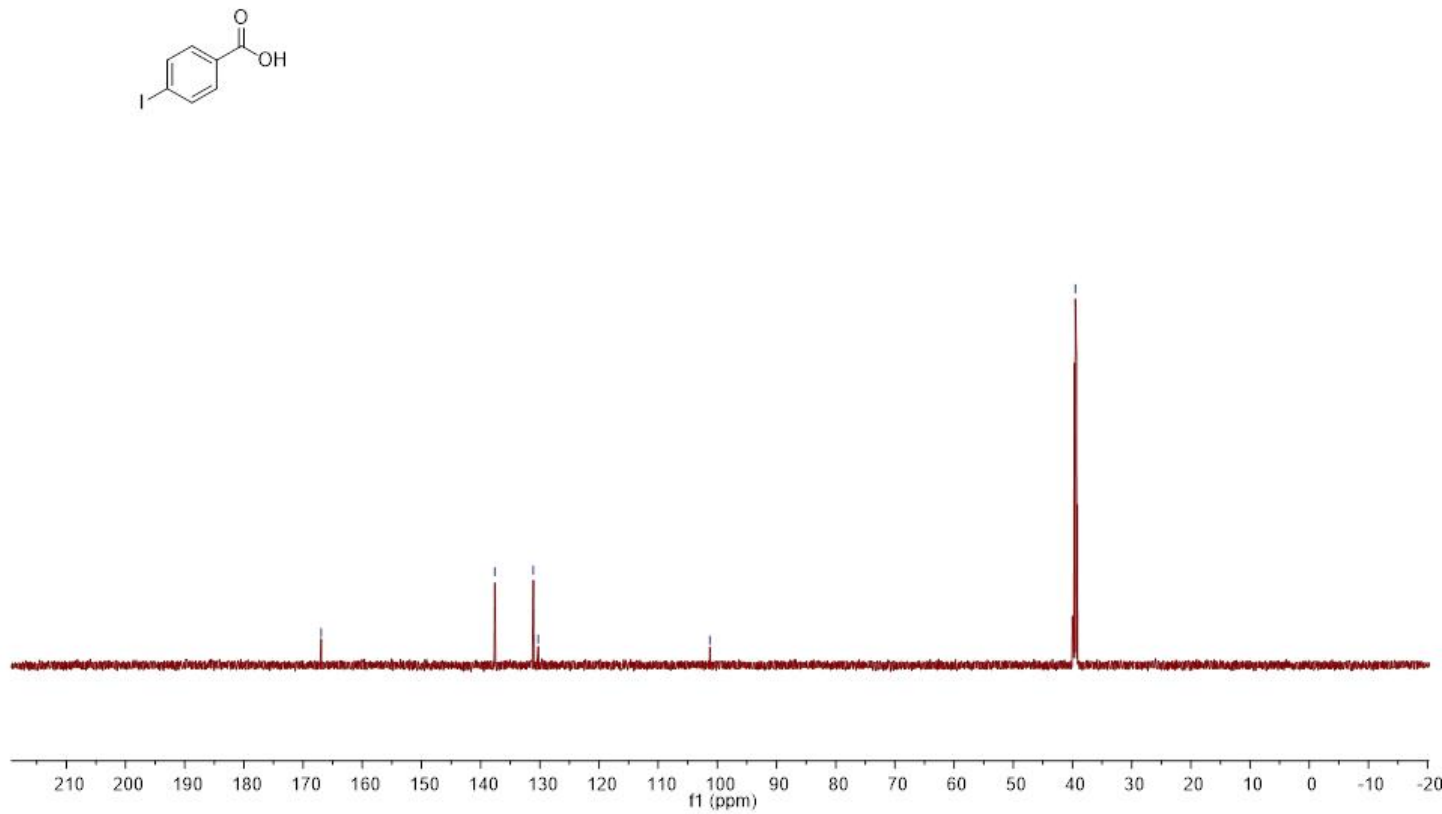
4-Bromobenzoic acid (3f, $500 \mathrm{MHz}$ for ${ }^{1} \mathrm{H}$ and $125 \mathrm{MHz}$ for ${ }^{13} \mathrm{C}\left\{{ }^{1} \mathrm{H}\right\}$ in DMSO- $d_{6}$ )
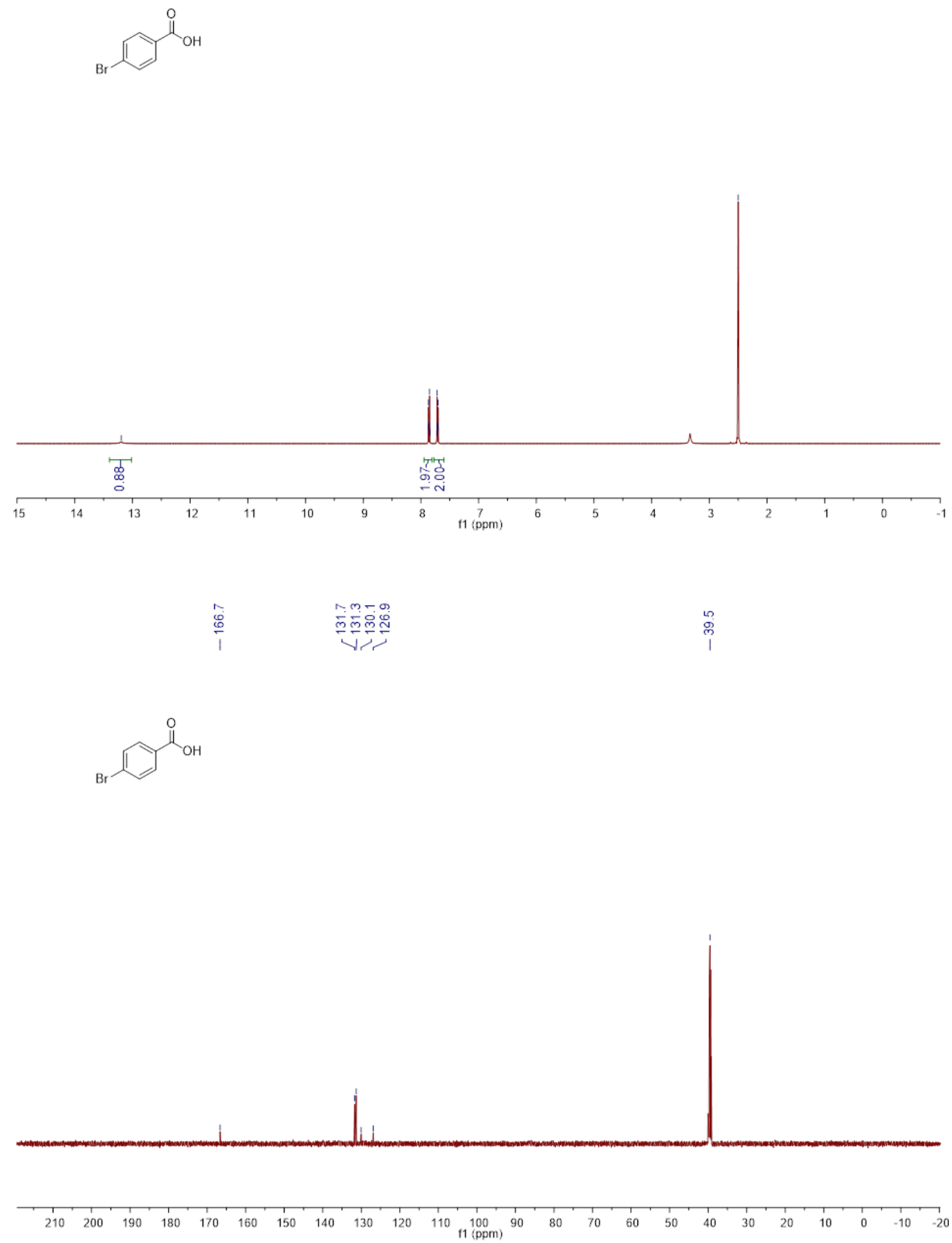
4-Fluorobenzoic acid (3g, $500 \mathrm{MHz}$ for ${ }^{1} \mathrm{H}$ and $125 \mathrm{MHz}$ for ${ }^{13} \mathrm{C}\left\{{ }^{1} \mathrm{H}\right\}$ in DMSO- $d_{6}$ )
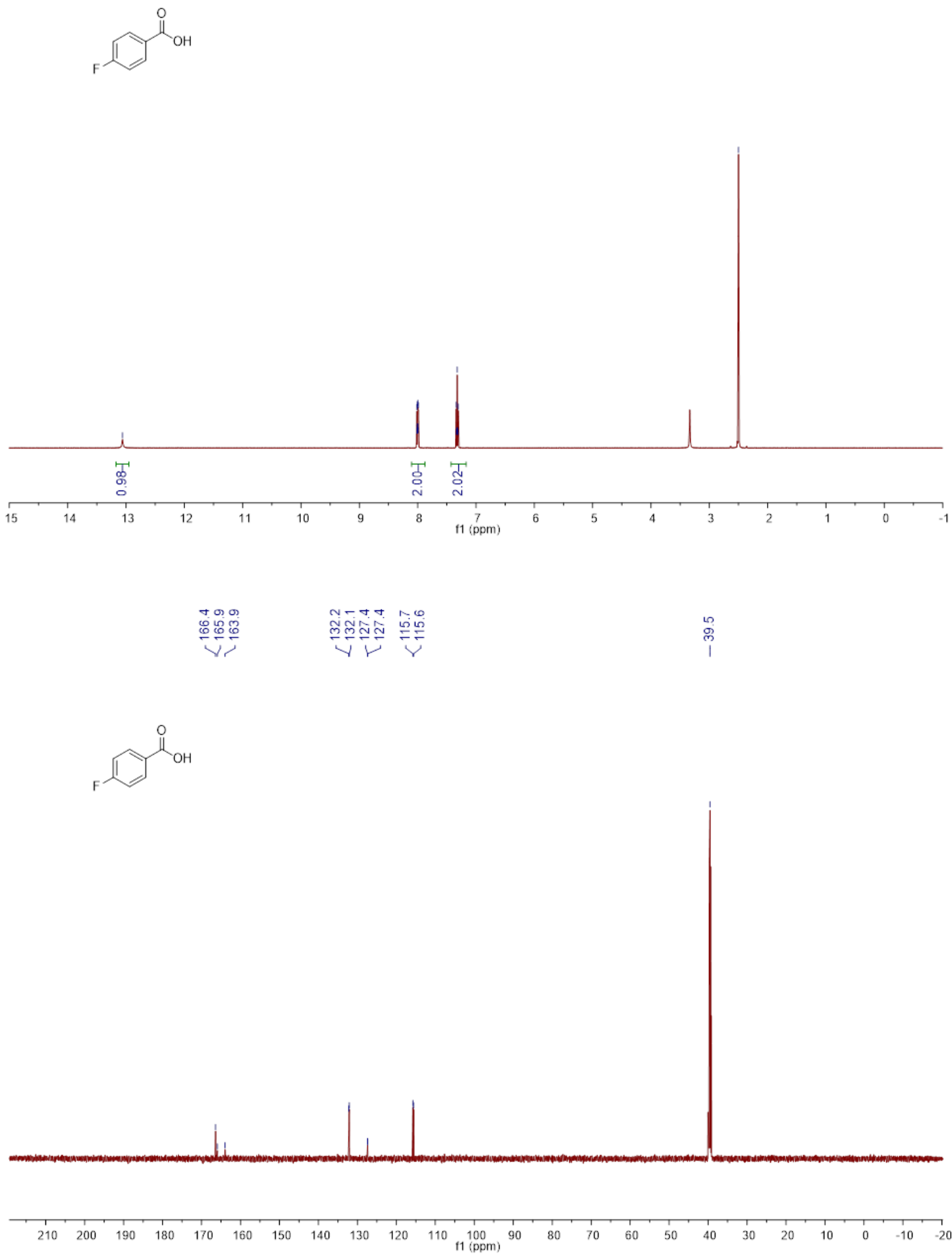
4-Chlorobenzoic acid (3h, $500 \mathrm{MHz}$ for ${ }^{1} \mathrm{H}$ and $125 \mathrm{MHz}$ for ${ }^{13} \mathrm{C}\left\{{ }^{1} \mathrm{H}\right\}$ in DMSO- $d_{6}$ )
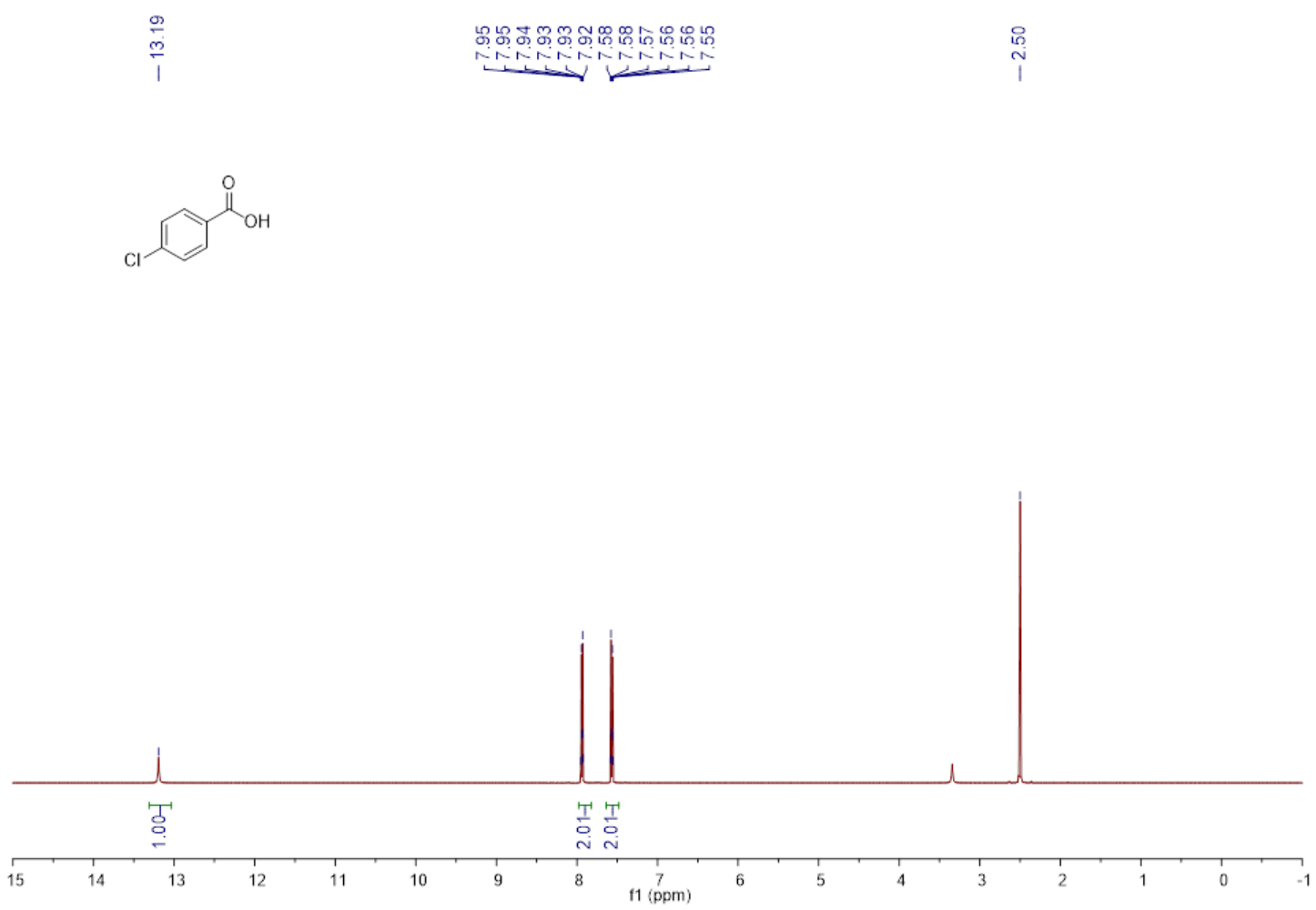

1
0
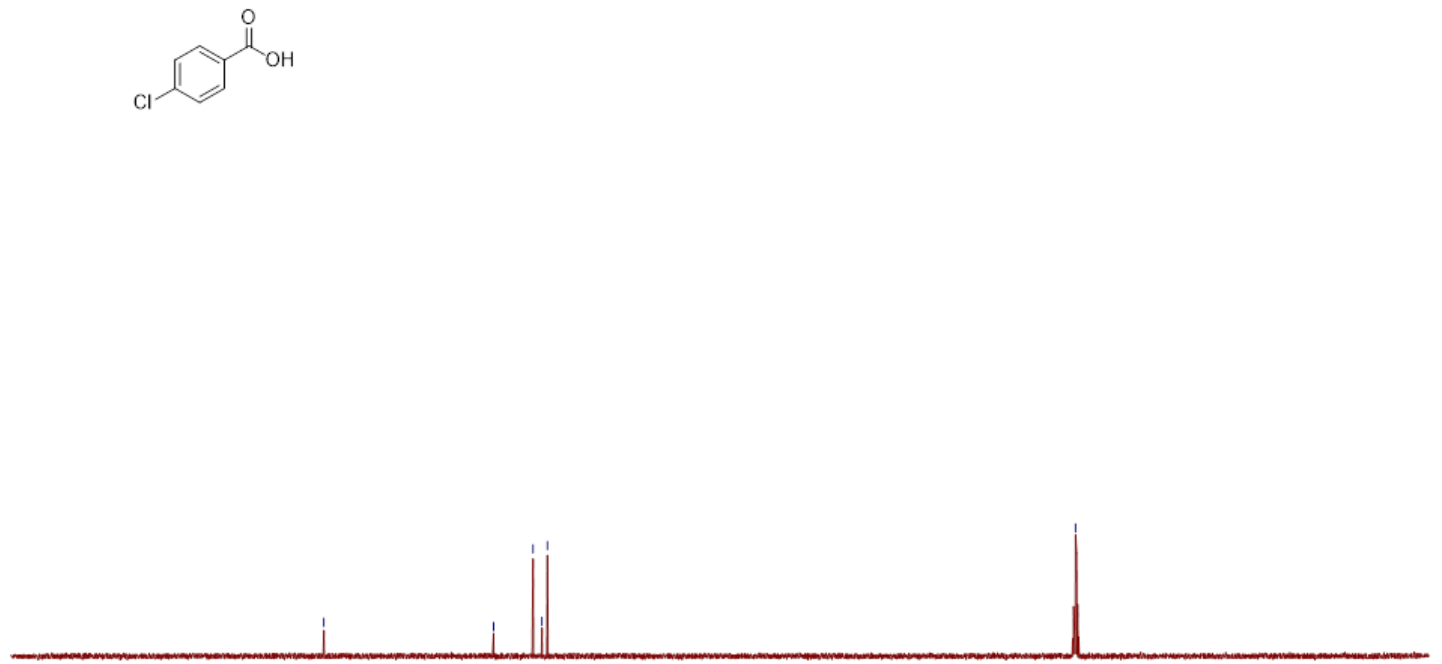

$\begin{array}{llllllllllllllllllllllllllll}210 & 200 & 190 & 180 & 170 & 160 & 150 & 140 & 130 & 120 & 110 & 100 & 90 & 80 & 70 & 60 & 50 & 40 & 30 & 20 & 10 & 0 & -10 & -20\end{array}$ 
3-Chlorobenzoic acid (3i, $500 \mathrm{MHz}$ for ${ }^{1} \mathrm{H}$ and $125 \mathrm{MHz}$ for ${ }^{13} \mathrm{C}\left\{{ }^{1} \mathrm{H}\right\}$ in DMSO-d $)$
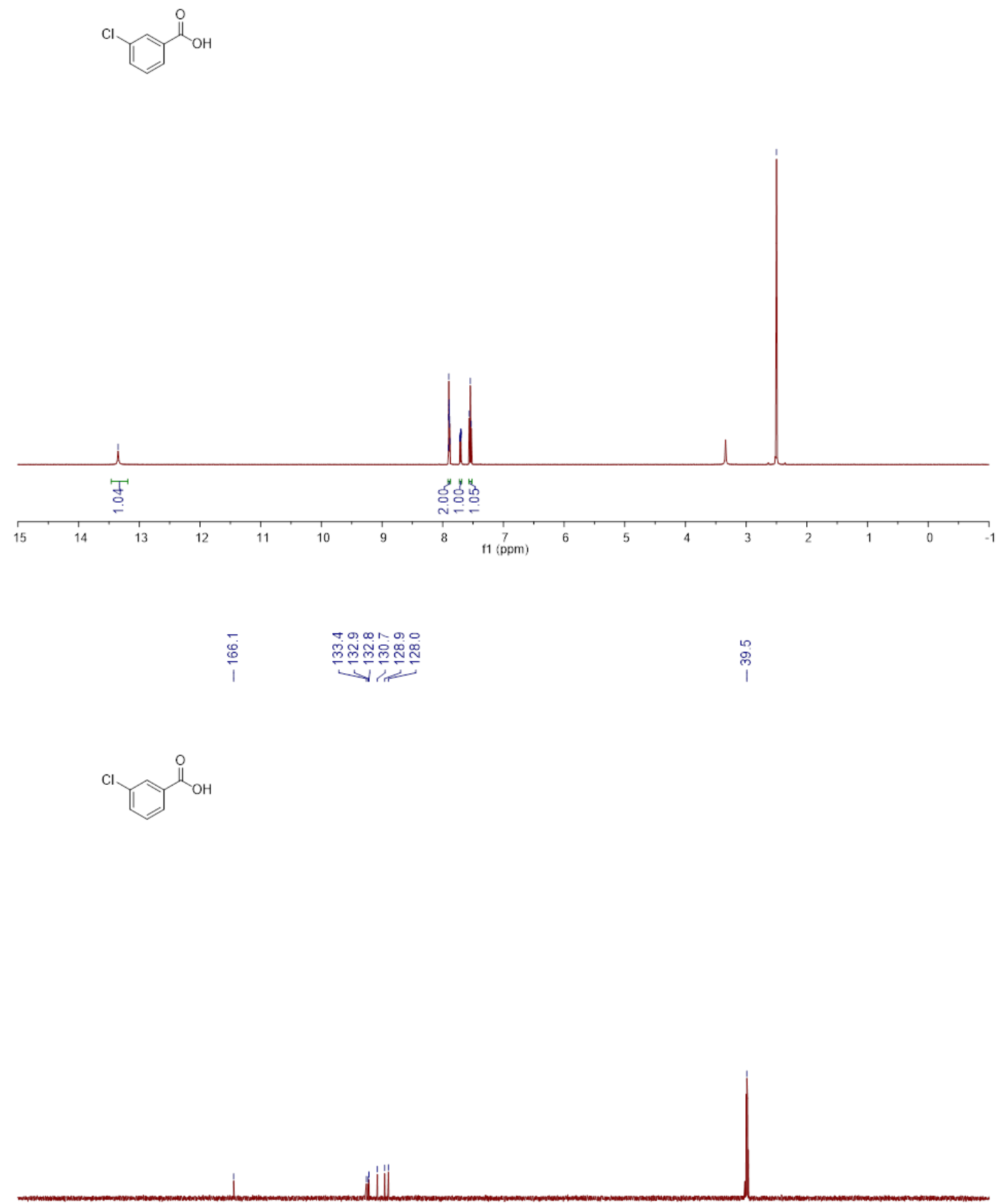

$\begin{array}{llllllllllllllllllllllllllll}210 & 200 & 190 & 180 & 170 & 160 & 150 & 140 & 130 & 120 & 110 & 100 & 90 & 80 & 70 & 60 & 50 & 40 & 30 & 20 & 10 & 0 & -10 & -20\end{array}$ 
2-Chlorobenzoic acid (3j, $500 \mathrm{MHz}$ for ${ }^{1} \mathrm{H}$ and $125 \mathrm{MHz}$ for ${ }^{13} \mathrm{C}\left\{{ }^{1} \mathrm{H}\right\}$ in DMSO-d6)
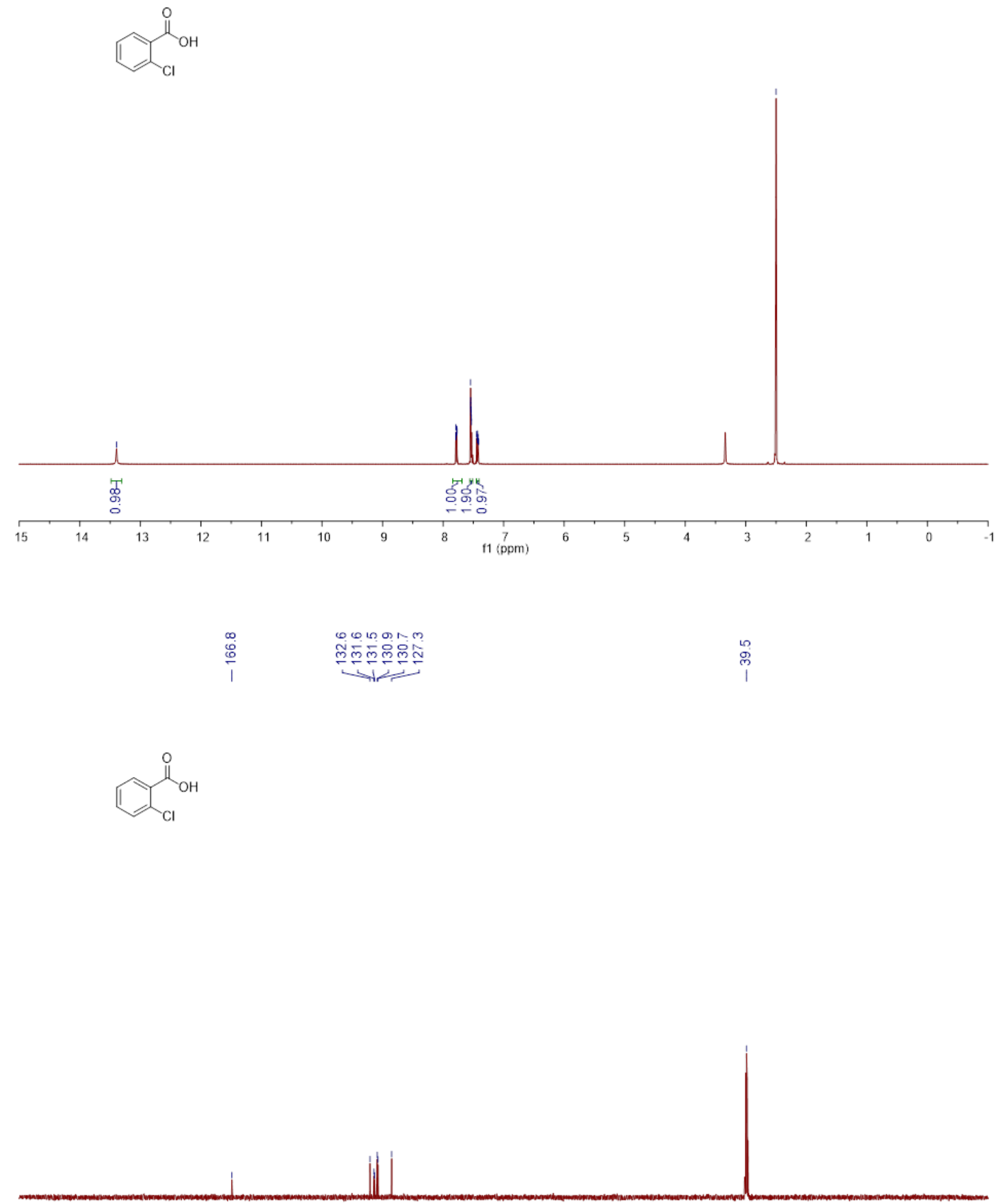

\begin{tabular}{lllllllllllllllllllllllllll}
\hline & 210 & 200 & 190 & 180 & 170 & 160 & 150 & 140 & 130 & 120 & 110 & 100 & 90 & 80 & 70 & 60 & 50 & 40 & 30 & 20 & 10 & 0 & -10 & -20
\end{tabular} 
2,4-Dichlorobenzoic acid (3k, $500 \mathrm{MHz}$ for ${ }^{1} \mathrm{H}$ and $125 \mathrm{MHz}$ for ${ }^{13} \mathrm{C}\left\{{ }^{1} \mathrm{H}\right\}$ in DMSO-d $\left.d_{6}\right)$<smiles>O=C(O)c1ccc(Cl)cc1Cl</smiles>

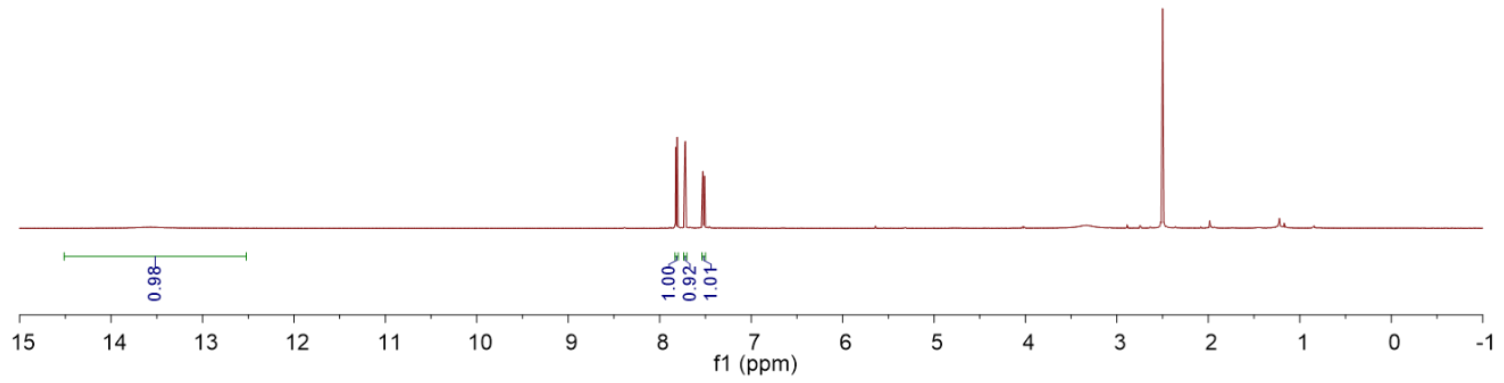

i.<smiles>O=C(O)c1ccc(Cl)cc1Cl</smiles>

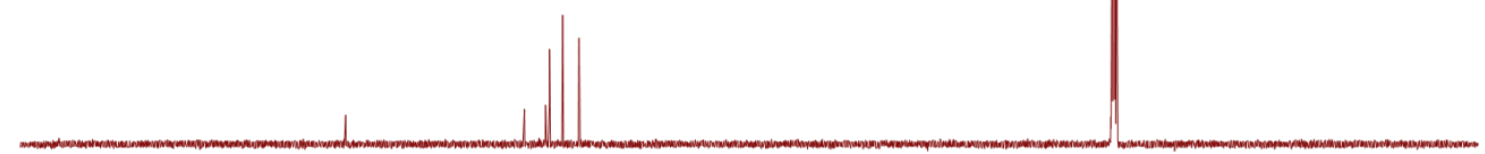

$\begin{array}{lllllllllllllllllllllll}210 & 190 & 170 & 150 & 130 & 110 & 90 & 80 & 70 & 60 & 50 & 40 & 30 & 20 & 10 & 0 & -10 & -20\end{array}$


4-(Trifluoromethyl)benzoic acid (3I, $500 \mathrm{MHz}$ for ${ }^{1} \mathrm{H}$ and $125 \mathrm{MHz}$ for ${ }^{13} \mathrm{C}\left\{{ }^{1} \mathrm{H}\right\}$ in DMSO- $d_{6}$ )
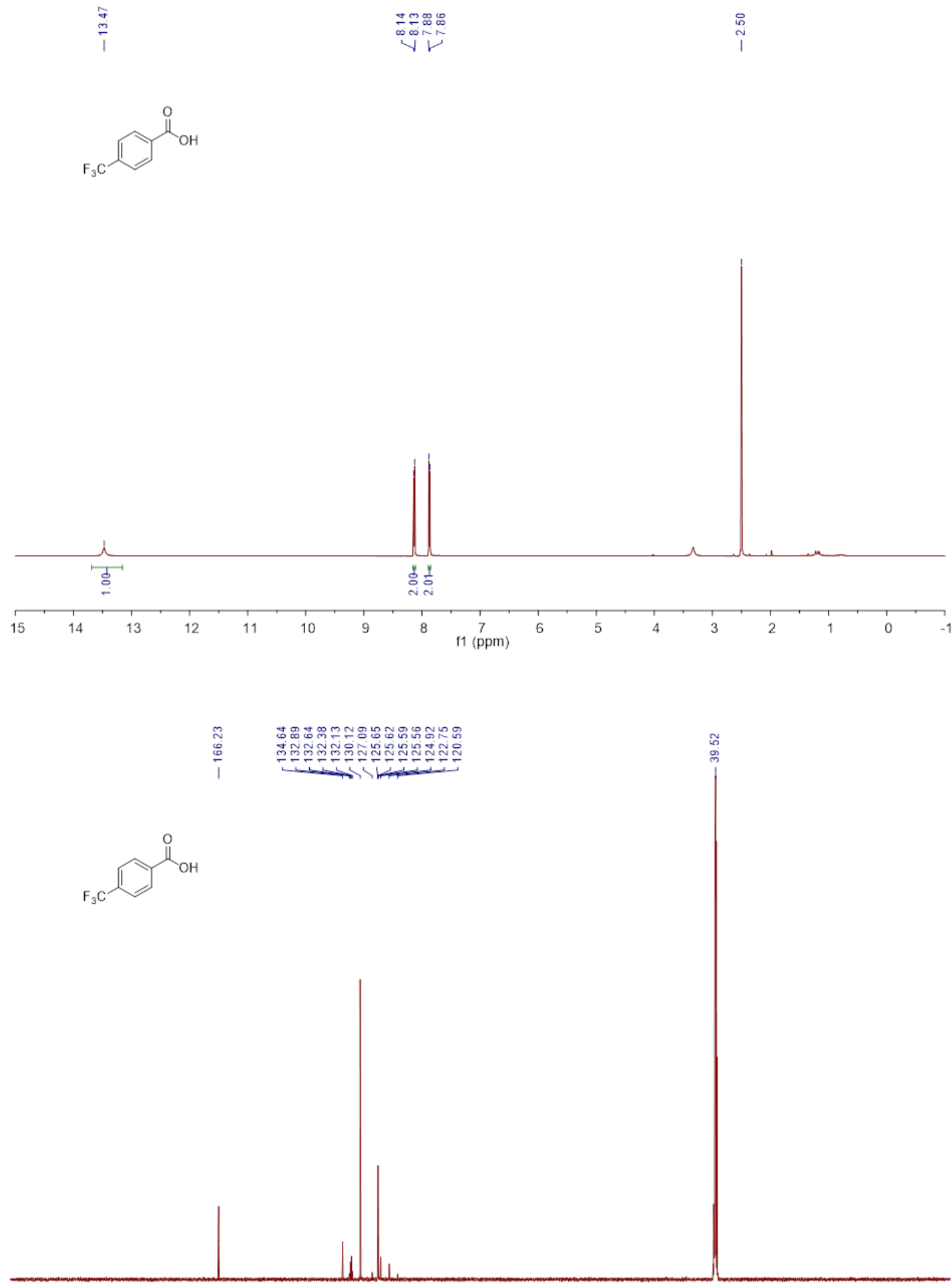

21

190

$\begin{array}{llllllllllll}110_{\mathrm{f} 1(\mathrm{ppm})}^{90} & 80 & 70 & 60 & 50 & 40 & 30 & 20 & 10 & 0 & -10 & -20\end{array}$ 
4-Acetamidobenzoic acid (3m, $500 \mathrm{MHz}$ for ${ }^{1} \mathrm{H}$ and $125 \mathrm{MHz}$ for ${ }^{13} \mathrm{C}\left\{{ }^{1} \mathrm{H}\right\}$ in DMSO-d6)

章

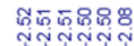

$\mathrm{H}_{\mathrm{H}}^{\mathrm{O}}$

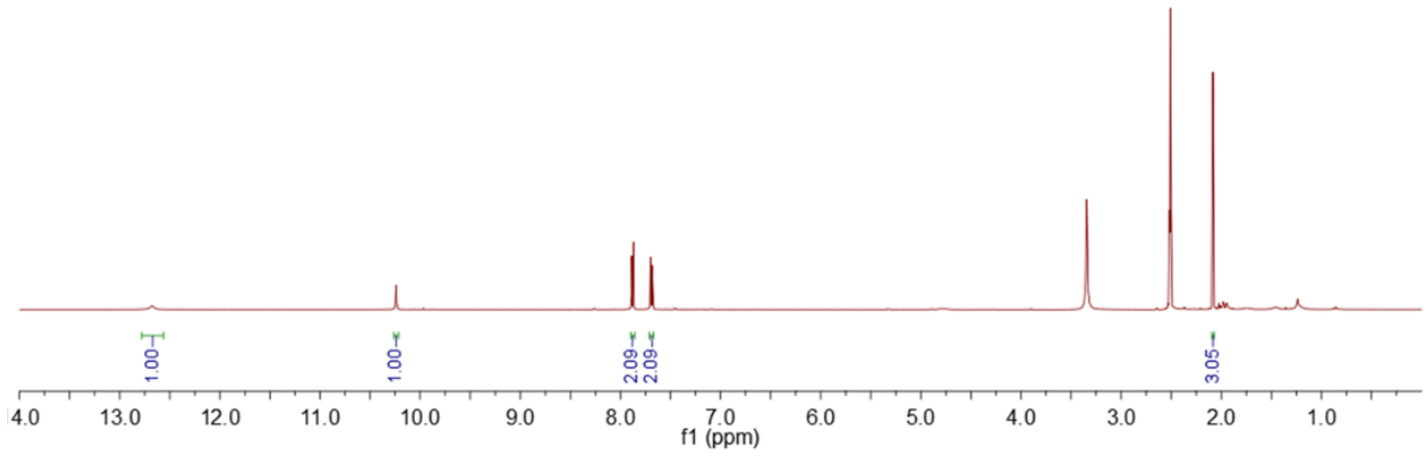

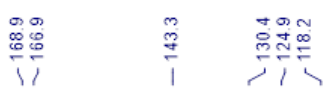<smiles>CC(=O)Nc1ccc(C(=O)O)cc1</smiles>

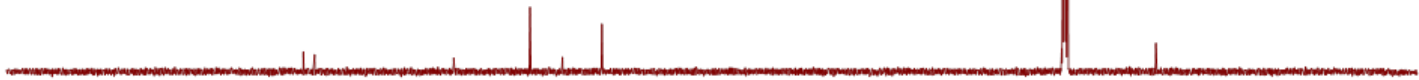

$\begin{array}{lllllllllllllllllllllll}1 & 190 & 170 & 150 & 130 & 110 & 90 & 80 & 70 & 60 & 50 & 40 & 30 & 20 & 10 & 0 & -10 & -26\end{array}$ 
4-Carboxyphenylboronic acid pinacol ester $\left(3 \mathrm{n}, 500 \mathrm{MHz}\right.$ for ${ }^{1} \mathrm{H}$ and $125 \mathrm{MHz}$ for ${ }^{13} \mathrm{C}\left\{{ }^{1} \mathrm{H}\right\}$ in DMSO$\left.d_{6}\right)$

$\stackrel{\circ}{\stackrel{m}{!}}$
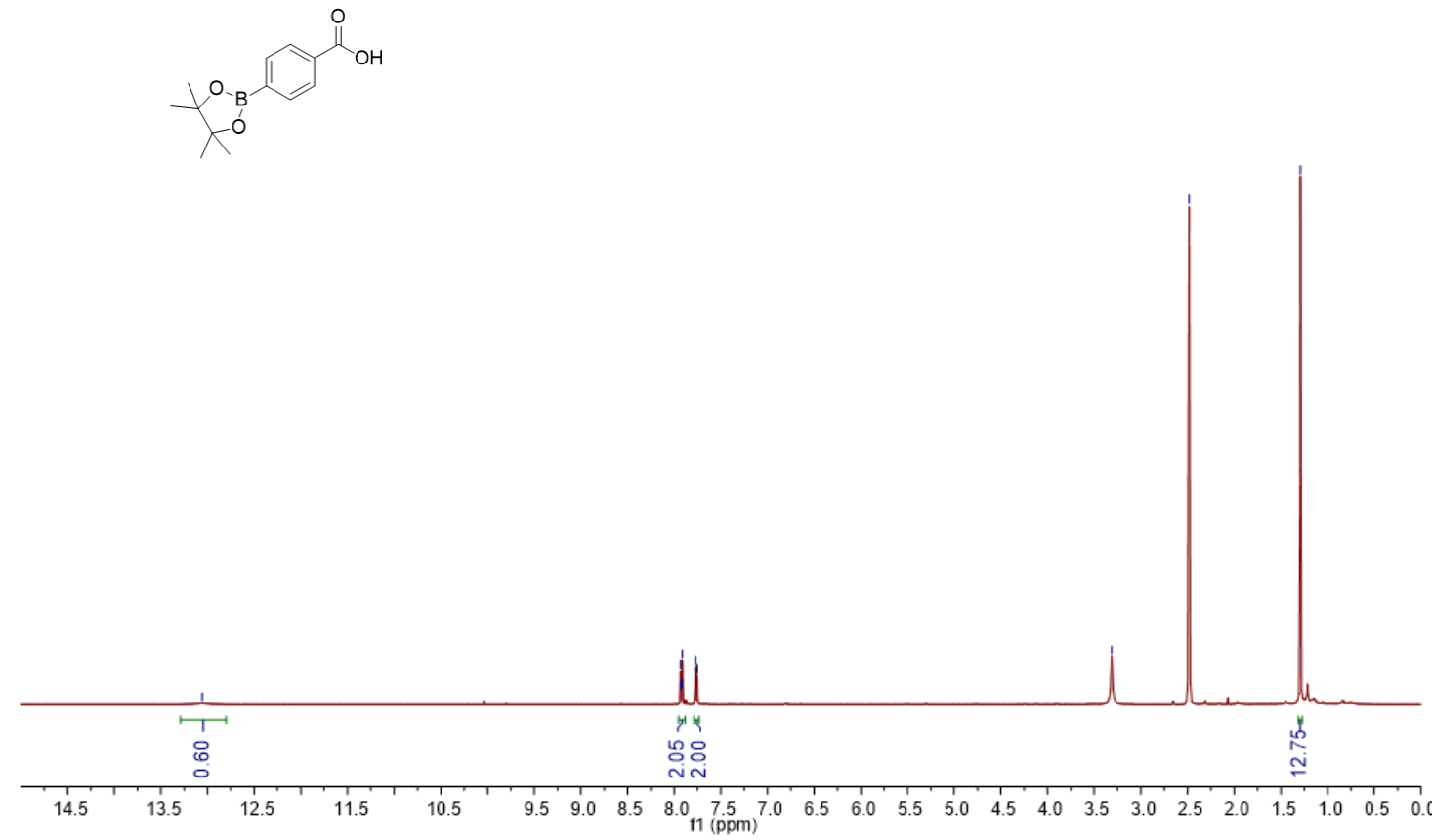

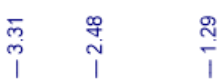

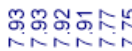

证然

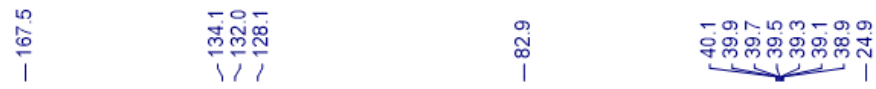
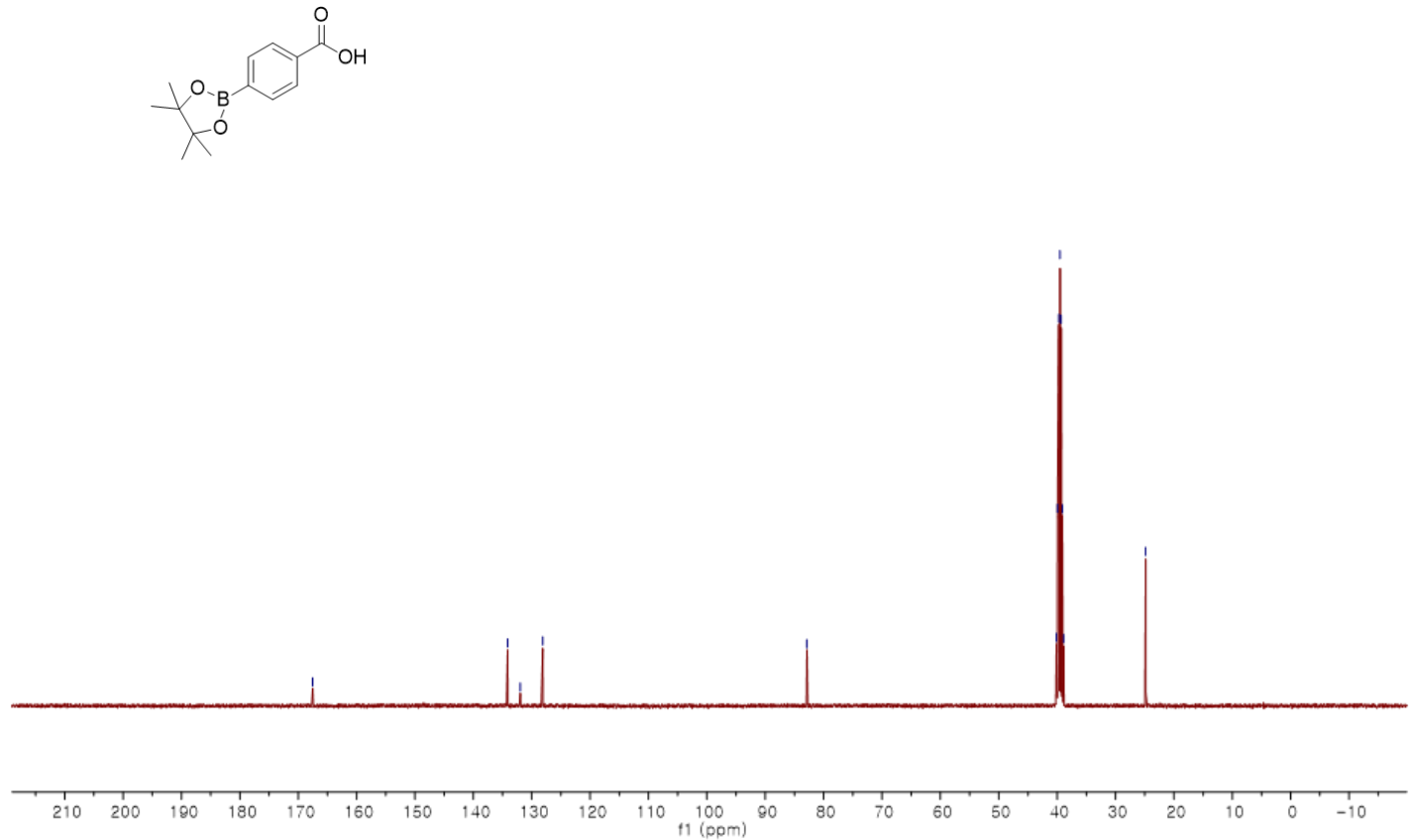
Terephthalic acid $\left(30,500 \mathrm{MHz}\right.$ for ${ }^{1} \mathrm{H}$ and $125 \mathrm{MHz}$ for ${ }^{13} \mathrm{C}\left\{{ }^{1} \mathrm{H}\right\}$ in DMSO- $d_{6}$ )

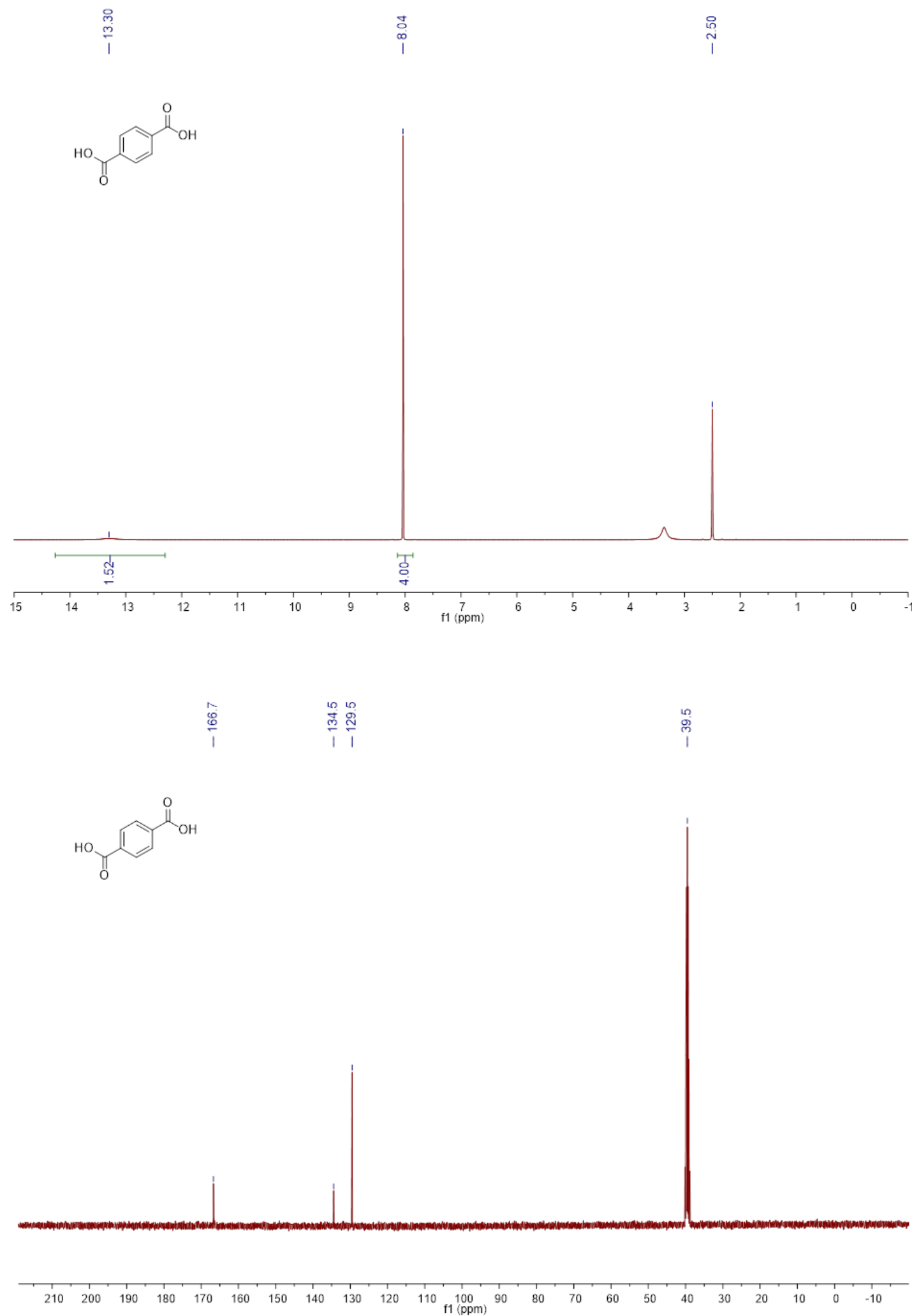


Biphenyl-4-carboxylic acid (3p, $500 \mathrm{MHz}$ for ${ }^{1} \mathrm{H}$ and $125 \mathrm{MHz}$ for ${ }^{13} \mathrm{C}\left\{{ }^{1} \mathrm{H}\right\}$ in DMSO-d 6 )
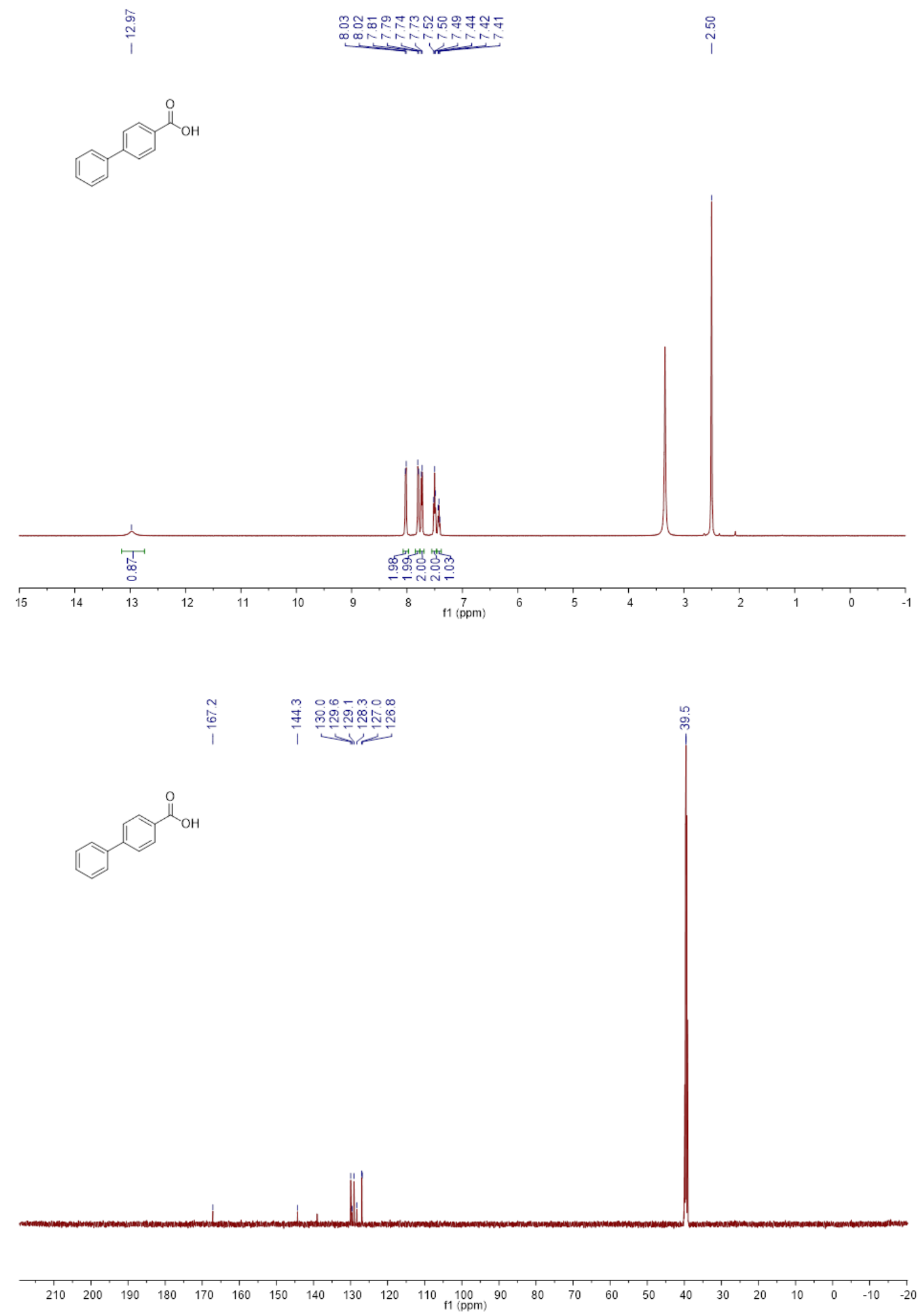
2-Furoic acid (3q, $500 \mathrm{MHz}$ for ${ }^{1} \mathrm{H}$ and $125 \mathrm{MHz}$ for ${ }^{13} \mathrm{C}\left\{{ }^{1} \mathrm{H}\right\}$ in DMSO- $d_{6}$ )

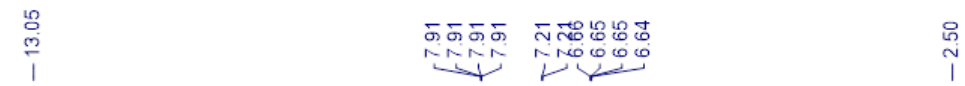

II

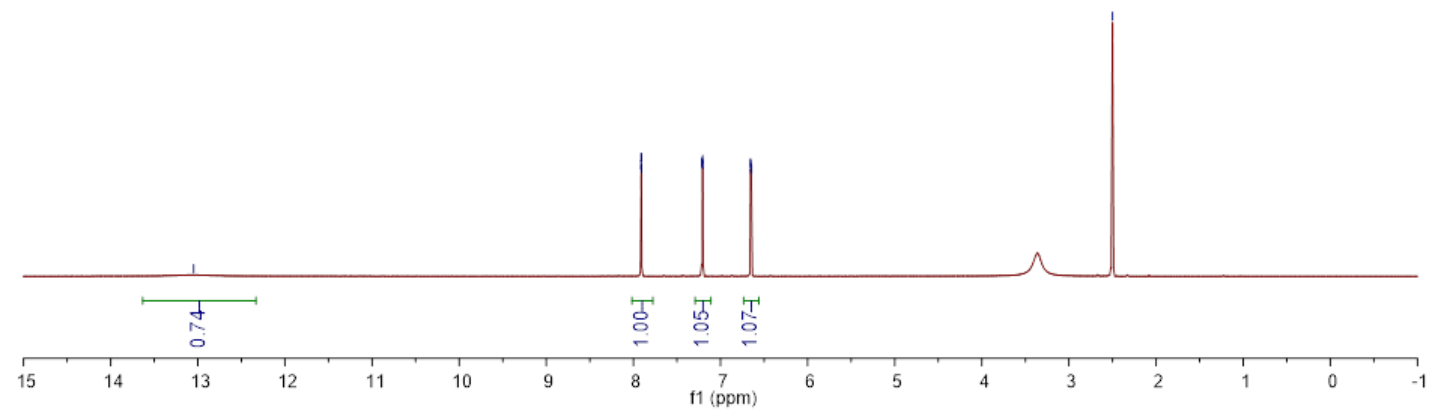

䏛 筞导

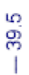

${ }_{11}^{\mathrm{O}} \mathrm{OH}$

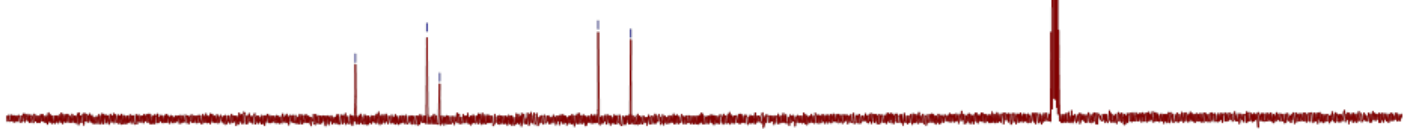

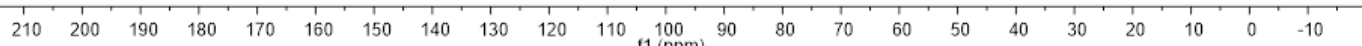


2,5-Furandicarboxylic acid (3r, $500 \mathrm{MHz}$ for ${ }^{1} \mathrm{H}$ and $125 \mathrm{MHz}$ for ${ }^{13} \mathrm{C}\left\{{ }^{1} \mathrm{H}\right\}$ in MeOD- $\left.d_{4}\right)$

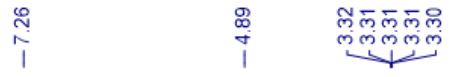
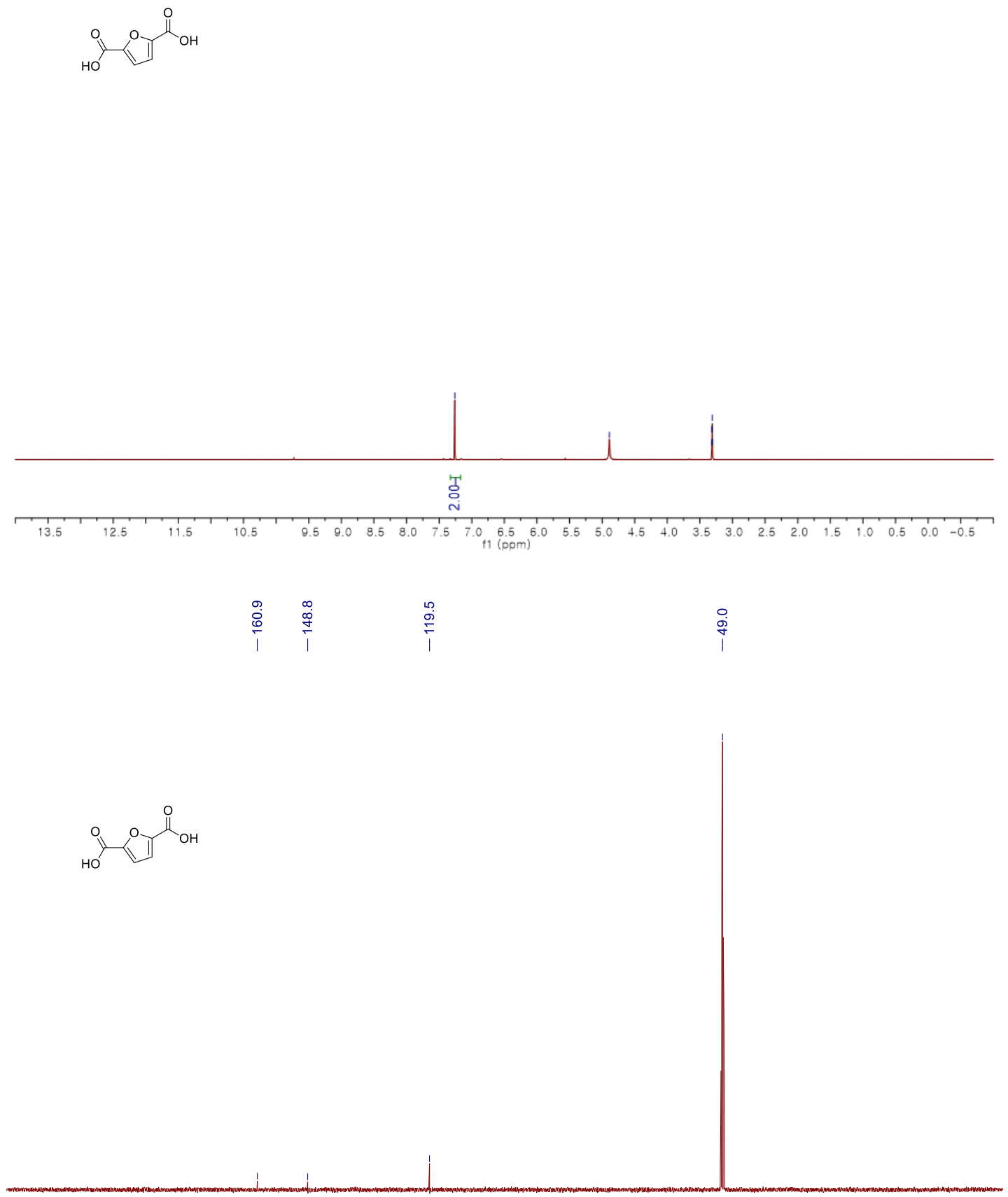

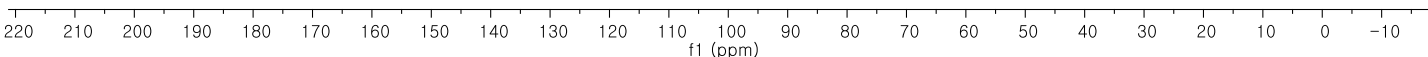


2-Thiophenecarboxylic acid (3s, $500 \mathrm{MHz}$ for ${ }^{1} \mathrm{H}$ and $125 \mathrm{MHz}$ for ${ }^{13} \mathrm{C}\left\{{ }^{1} \mathrm{H}\right\}$ in $\mathrm{CDCl}_{3}$ )

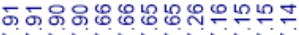

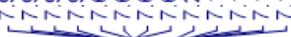

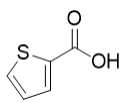

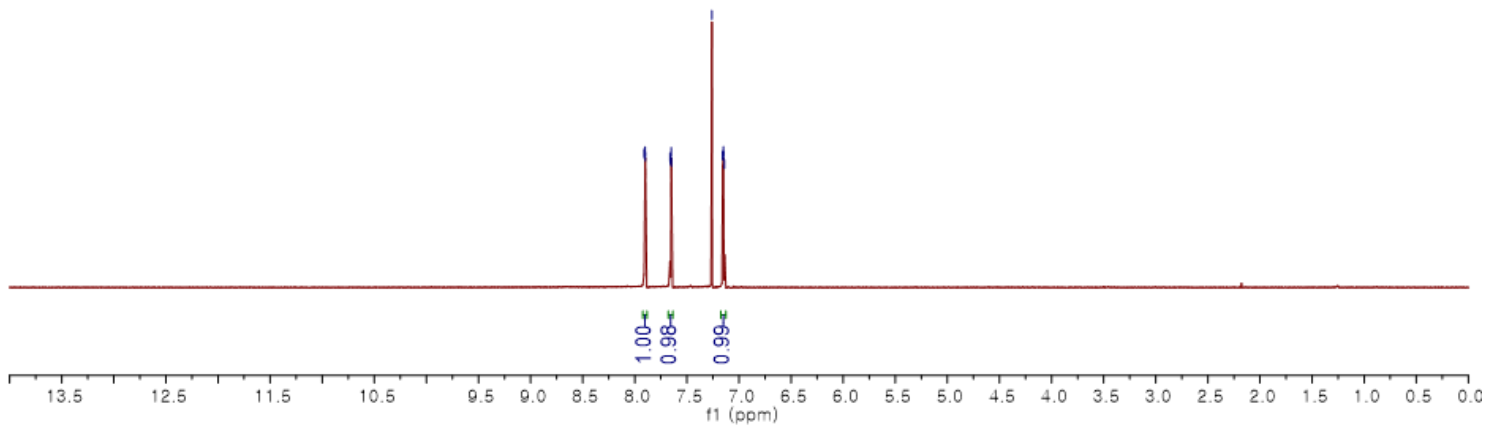

定

SII

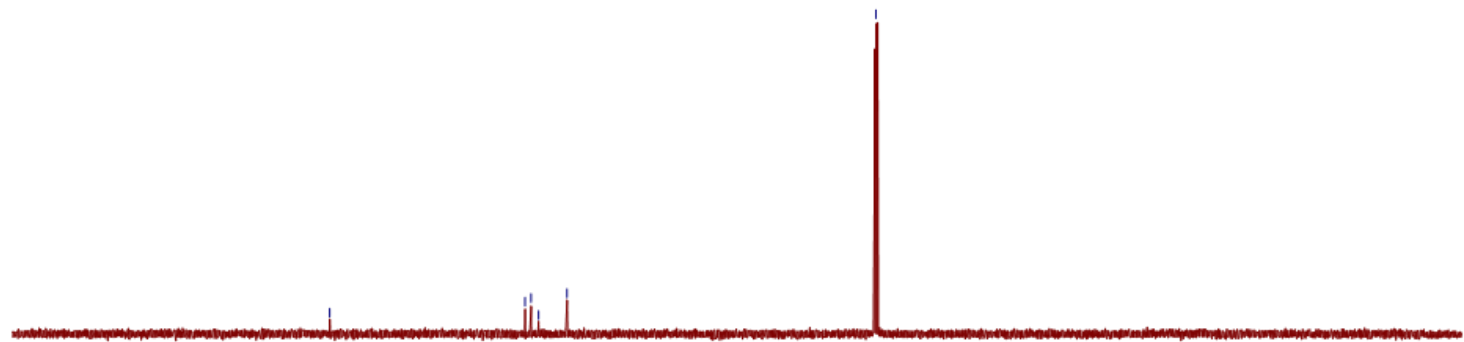

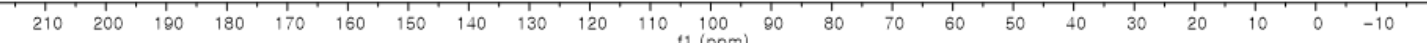


3-Thiophenecarboxylic acid (3t, $500 \mathrm{MHz}$ for ${ }^{1} \mathrm{H}$ and $125 \mathrm{MHz}$ for ${ }^{13} \mathrm{C}\left\{{ }^{1} \mathrm{H}\right\}$ in DMSO- $d_{6}$ )

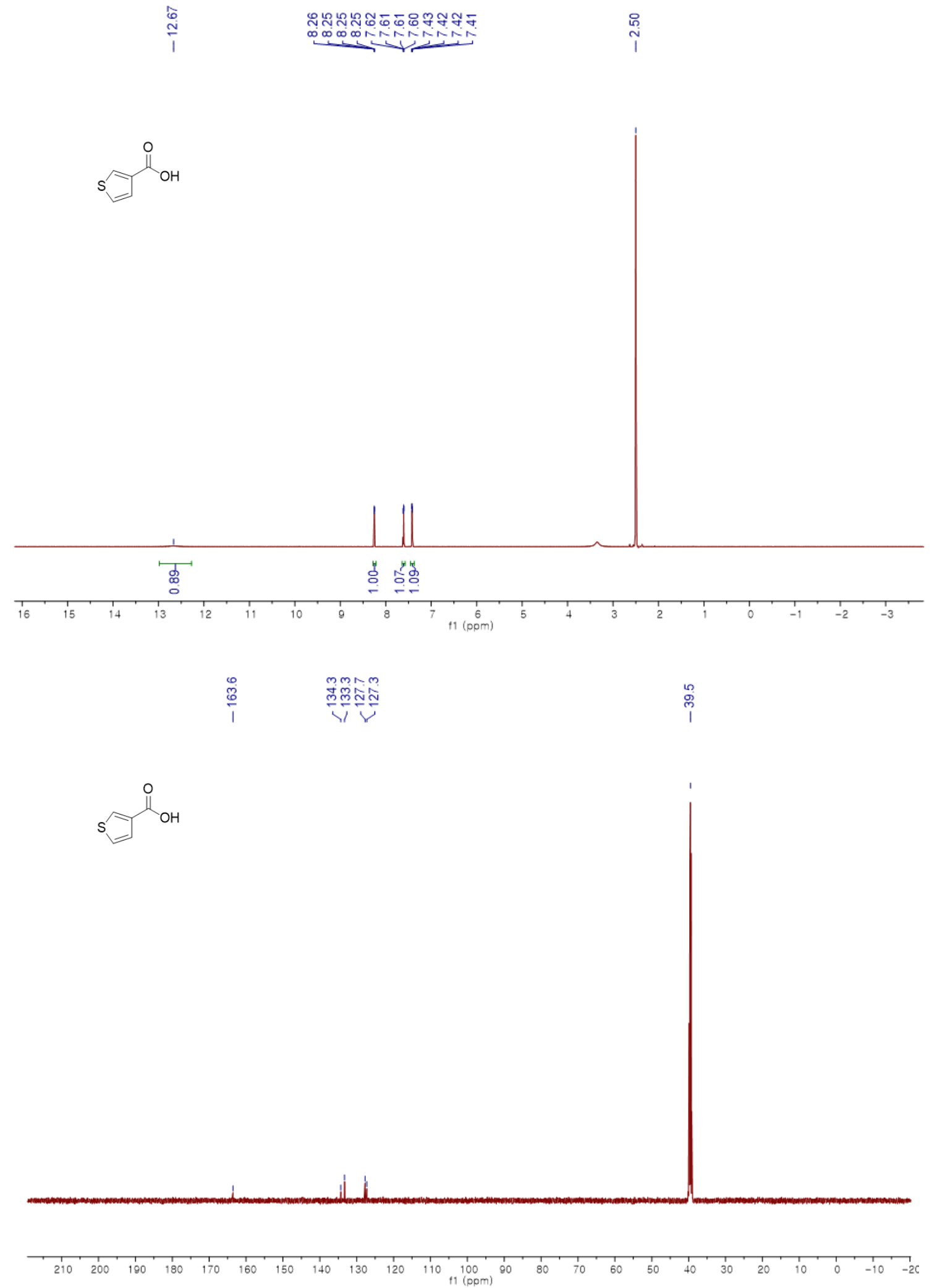


Hexanoic acid $\left(3 \mathrm{u}, 500 \mathrm{MHz}\right.$ for ${ }^{1} \mathrm{H}$ and $125 \mathrm{MHz}$ for ${ }^{13} \mathrm{C}\left\{{ }^{1} \mathrm{H}\right\}$ in DMSO- $\left.d_{6}\right)$

$$
\stackrel{\text { बे }}{\stackrel{5}{人}}
$$
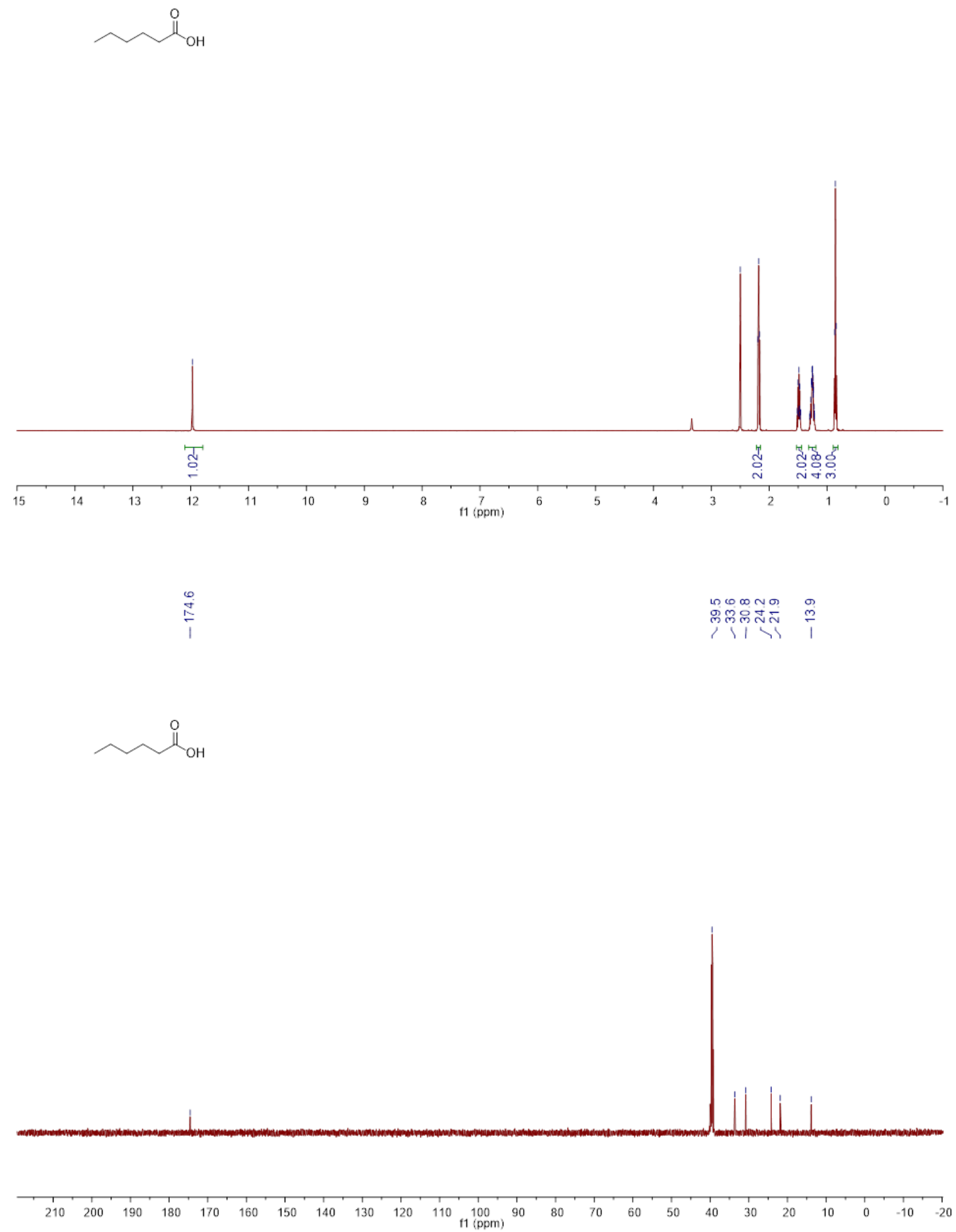
Dodecanoic acid (3g, $500 \mathrm{MHz}$ for ${ }^{1} \mathrm{H}$ and $125 \mathrm{MHz}$ for ${ }^{13} \mathrm{C}\left\{{ }^{1} \mathrm{H}\right\}$ in $\left.\mathrm{CDCl}_{3}\right)$

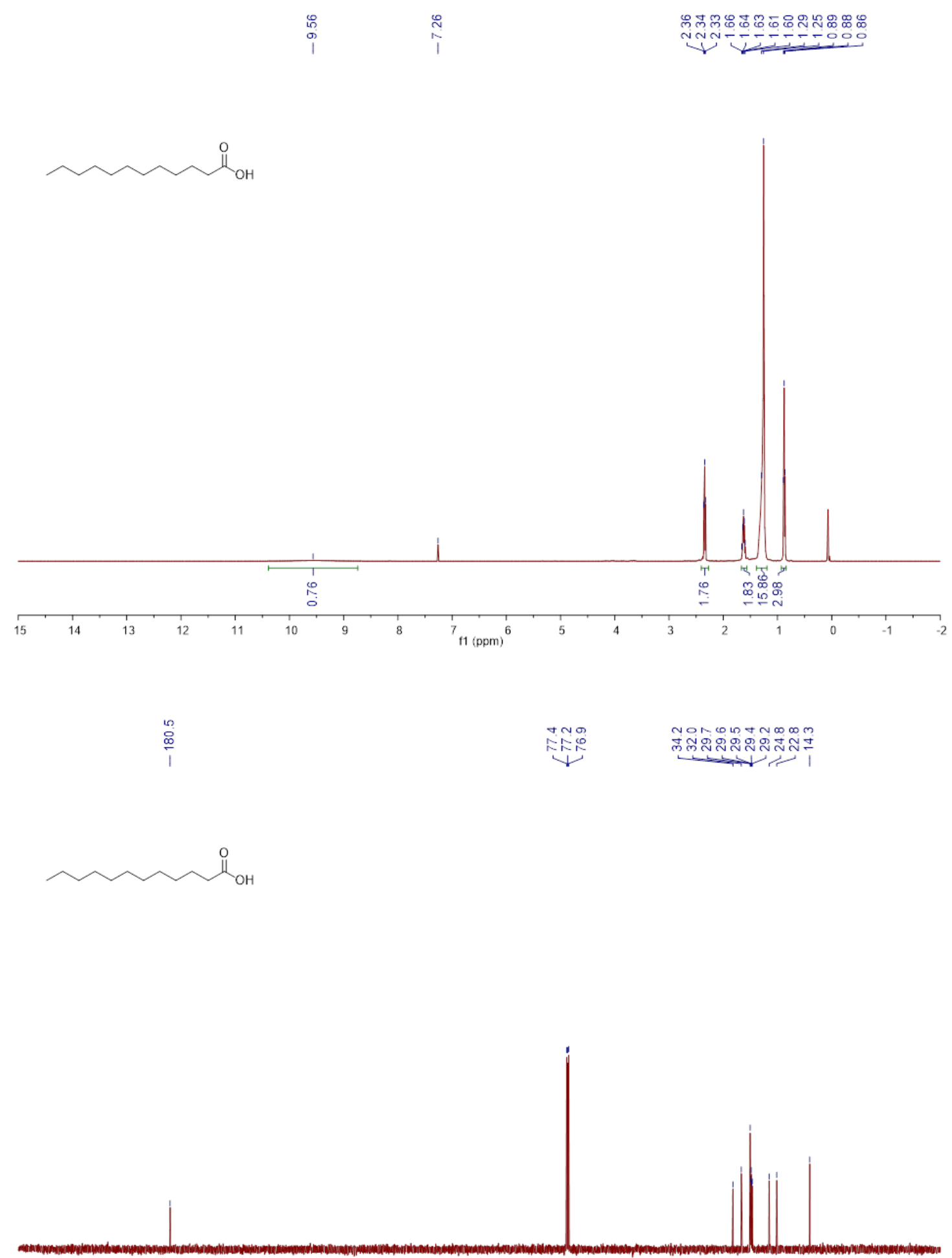

$\begin{array}{llllllllllllllllllllllllllll}1 & 210 & 200 & 190 & 180 & 170 & 160 & 150 & 140 & 130 & 120 & 110 & 100 & 90 & 80 & 70 & 60 & 50 & 40 & 30 & 20 & 10 & 0 & -10\end{array}$ 


\section{References for supporting information}

S1 Zhuang, J. L.; Liu, X. Y.; Zhang, Y.; Wang, C.; Mao, H. L.; Guo, J.; Du, X.; Zhu, S. B.; Ren, B.; Terfort, A. Zr-Metal-Organic Frameworks Featuring TEMPO Radicals: Synergistic Effect between TEMPO and Hydrophilic Zr-Node Defects Boosting Aerobic Oxidation of Alcohols. ACS Appl. Mater. Interfaces 2019, 11, 3034-3043.

S2 Liu, K.-J.; Fu, Y.-L.; , L.-Y.; Wu, C.; He, W.-B.; Peng, S.; Wang, Z.; Bao, W.-H.; Cao, Z.; Xu, X.; He, W.-M. Green and Efficient: Oxidation of Aldehydes to Carboxylic Acids and Acid Anhydrides with Air. ACS Sustainable Chem . Eng. 2018, 6, 4916-4921.

S3 Babu, S. S.; Shanmugam, S. CAN-Supported Chemoselective Oxidative Conversion of $\alpha-$ Aroylketene-(S,S)-acetals to Aryl Carboxylic Acids. ChemistrySelect 2017, 2, 2330-2334.

S4 Rahaim, R. J.; Maleczka, R. E. Pd-Catalyzed Silicon Hydride Reductions of Aromatic and Aliphatic Nitro Groups. Org. Lett. 2005, 7, 5087-5090.

S5 Kumar, A.; Ye, G.; Ahmadibeni, Y.; Parang, K. Synthesis of Polymer-Bound 4-Acetoxy-3phenylbenzaldehyde Derivatives: Applications in Solid-Phase Organic Synthesis. J. Org. Chem. 2006, 71, 7915-7918.

S6 Hazra, S.; Deb, M.; Elias, A. J. lodine catalyzed oxidation of alcohols and aldehydes to carboxylic acids in water: a metal-free route to the synthesis of furandicarboxylic acid and terephthalic acid.Green Chem. 2017, 19, 5548-5552.

S7 Yang, D.; Yang, H.; Fu, H. Copper-catalyzed aerobic oxidative synthesis of aromatic carboxylic acids. Chem. Commun. 2011, 47, 2348-2350.

S8 He, X.; Shen, Z.; Mo, W.; Sun, N.; Hu, B.; Hu, X. TEMPO-tert-Butyl Nitrite: An Efficient Catalytic System for Aerobic Oxidation of Alcohols. Adv. Synth. Catal. 2009, 351, 89-92.

S9 Dutta, U.; Maity, S.; Kancherla, R.; Maiti, D. Aerobic Oxynitration of Alkynes with ${ }^{t} B u O N O$ and TEMPO. Org. Lett. 2014, 16, 6302-6305.

S10 Dai, J.-J.; Fang, C.; Xiao, B.; Yi, J.; Xu, J.; Liu, Z.-J.; Lu, X.; Liu, L.; Fu, Y. Copper-Promoted Sandmeyer Trifluoromethylation Reaction. J. Am. Chem. Soc. 2013, 135, 8436-8439.

S11 Wang, X.; Xu, Y.; Mo, F.; Ji, G.; Qiu, D.; Feng, J.; Ye, Y.; Zhang, S.; Zhang, Y.; Wang, J. SilverMediated Trifluoromethylation of Aryldiazonium Salts: Conversion of Amino Group into Trifluoromethyl Group. J. Am. Chem. Soc. 2013, 135, 10330-10333.

S12 Miao, C.-X.; Yu, B.; He, L.-N. Tert-butyl nitrite: a metal-free radical initiator for aerobic cleavage of benzylic $\mathrm{C}=\mathrm{C}$ bonds in compressed carbon dioxide. Green Chem. 2011, 13, 541-544.

S13 Liu, Y.; Zhang, J.-L.; Song, R.-J.; Qian, P.-C.; Li, J.-H. Angew. Chem. Int. Ed. 2014, 53, 90179020.

S14 Yang, X.-H.; Ouyang, X.-H.; Wei, W.-T.; Song, R.-J.; Li, J.-H. Nitrative Spirocyclization Mediated by TEMPO: Synthesis of Nitrated Spirocycles from $\mathrm{N}$-Arylpropiolamides, tert-Butyl Nitrite and Water. Adv. Synth. Catal. 2015, 357, 1161-1166. 
S15 Yang, X.-H.; Song, R.-J.; Li, J.-H. Metal-Free [4+2] Annulation of Arylalkynes with tert-Butyl Nitrite through $\mathrm{C}\left(s p^{2}\right)$-H Oxidation to Assemble Benzo[e][1,2]oxazin-4-ones. Adv. Synth. Catal. 2015, 357, 3849-3856.

S16 Taniguchi, T.; Yajima, A.; Ishibashi, H. Oxidative Nitration of Alkenes with tert-Butyl Nitrite and Oxygen. Adv. Synth. Catal. 2011, 353, 2643-2647. 